Prepared in cooperation with the Town of Newtown, Connecticut

\title{
Hydrogeology and Numerical Simulation of the Unconsolidated Glacial Aquifer in the Pootatuck River Basin, Newtown, Connecticut
}

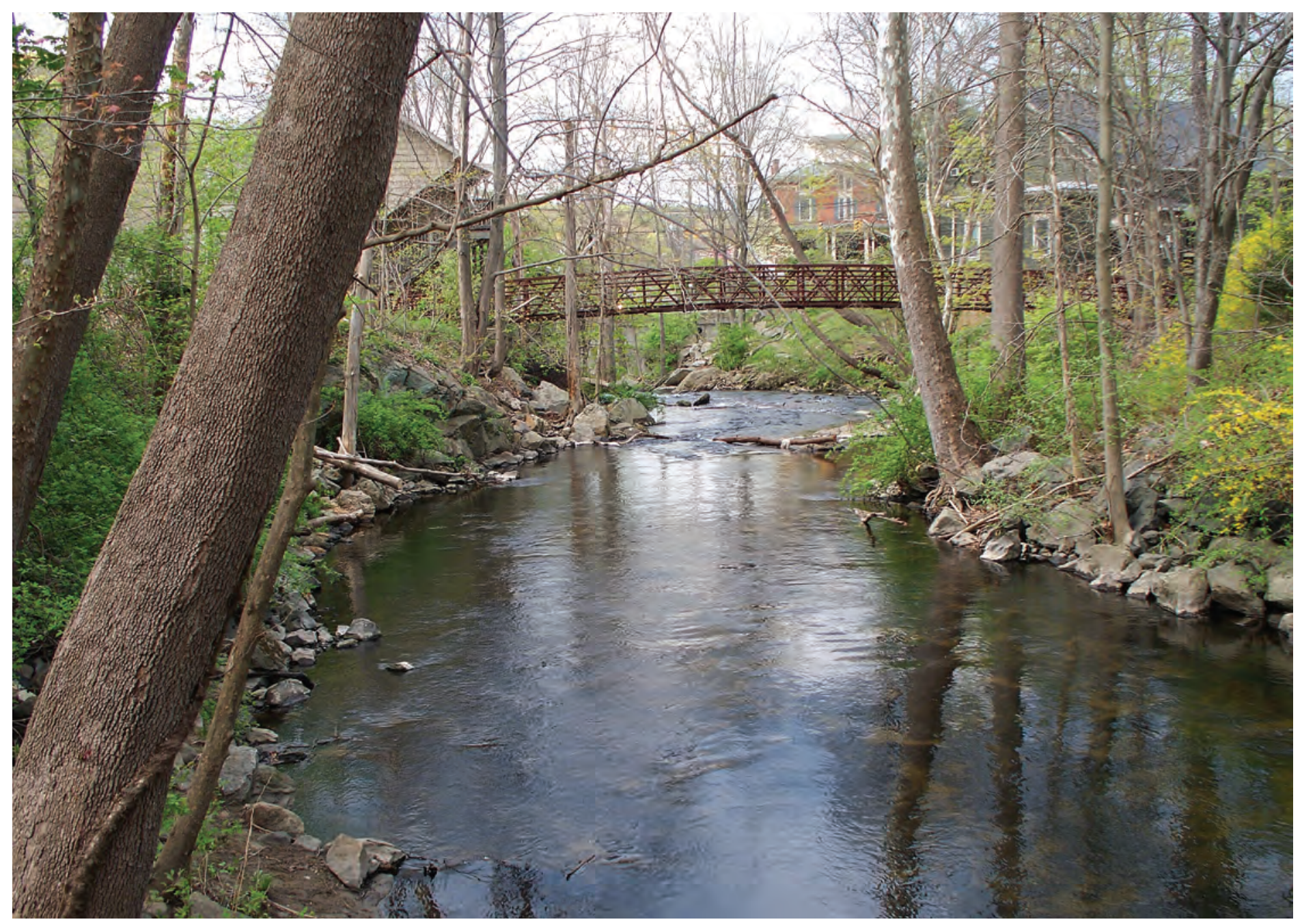

Scientific Investigations Report 2010-5142 
Cover. Pootatuck River looking downstream from streamgage at Sandy Hook, CT. Photo by Jason Pollender, U.S. Geological Survey, April 2010. 


\section{Hydrogeology and Numerical Simulation of the Unconsolidated Glacial Aquifer in the Pootatuck River Basin, Newtown, Connecticut}

By Carl S. Carlson, Remo A. Mondazzi, David M. Bjerklie, and Craig J. Brown

Prepared in cooperation with the Town of Newtown, Connecticut

Scientific Investigations Report 2010-5142 


\section{U.S. Department of the Interior \\ KEN SALAZAR, Secretary \\ U.S. Geological Survey \\ Marcia K. McNutt, Director}

U.S. Geological Survey, Reston, Virginia: 2010

For more information on the USGS - the Federal source for science about the Earth, its natural and living resources, natural hazards, and the environment, visit http://www.usgs.gov or call 1-888-ASK-USGS

For an overview of USGS information products, including maps, imagery, and publications, visit http://www.usgs.gov/pubprod

To order this and other USGS information products, visit http://store.usgs.gov

Any use of trade, product, or firm names is for descriptive purposes only and does not imply endorsement by the U.S. Government.

Although this report is in the public domain, permission must be secured from the individual copyright owners to reproduce any copyrighted materials contained within this report.

Suggested citation:

Carlson, C.S., Mondazzi, R.A., Bjerklie, D.M., and Brown, C.J., 2010, Hydrogeology and numerical simulation of the unconsolidated glacial aquifer in the Pootatuck River Basin, Newtown, Connecticut: U.S. Geological Survey Scientific Investigations Report 2010-5142, 84 p., at http://pubs.usgs.gov/sir/2010/5142/. 


\section{Contents}

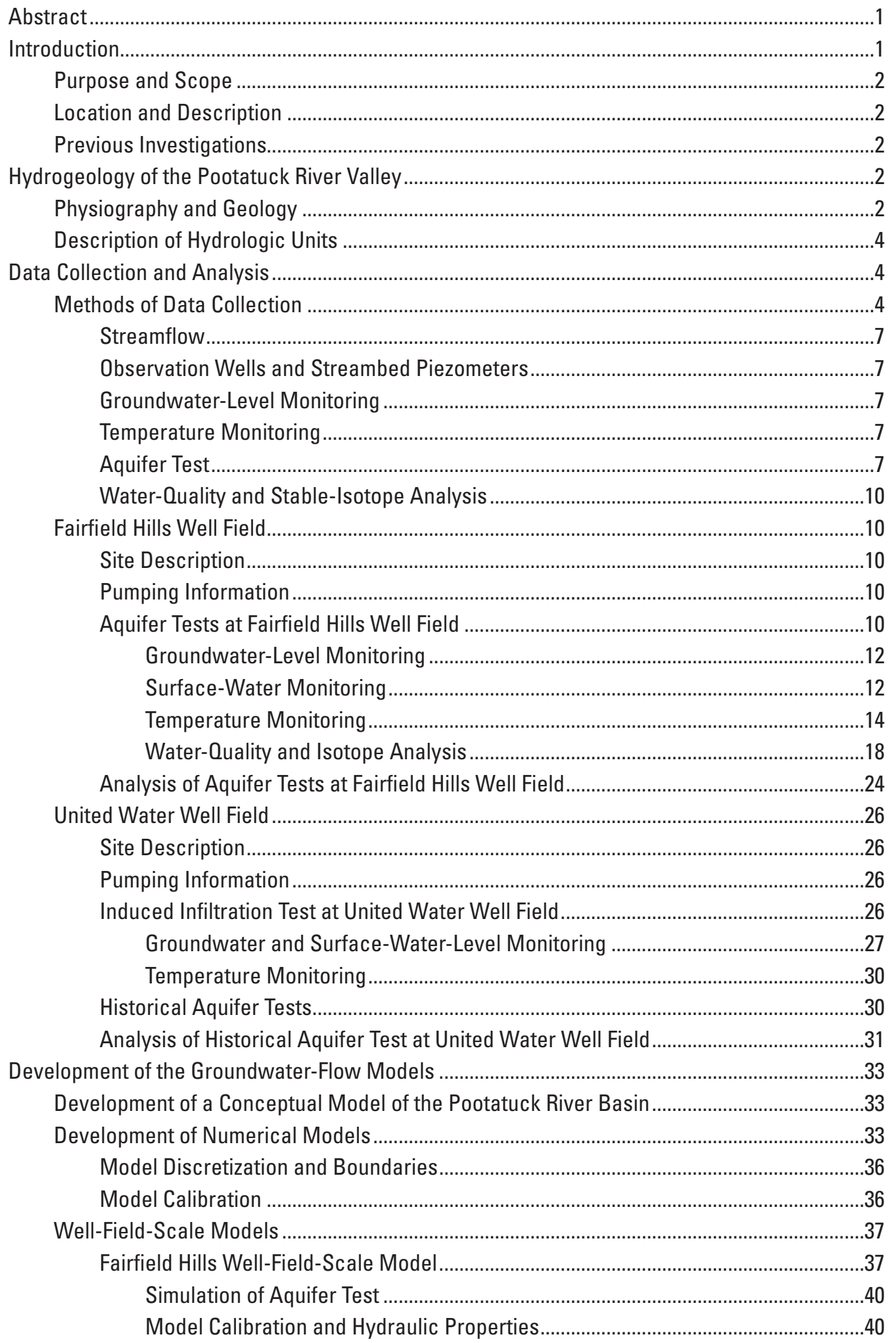




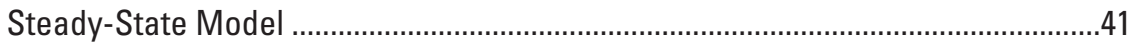

United Water Well-Field-Scale Model ........................................................................

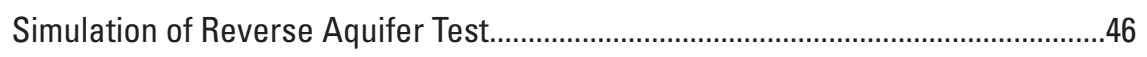

Model Calibration and Hydraulic Properties............................................................46

Limitations of Well-Field-Scale Models ..................................................................

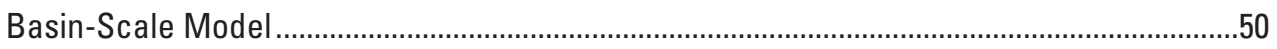

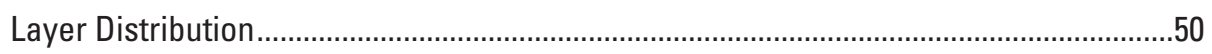

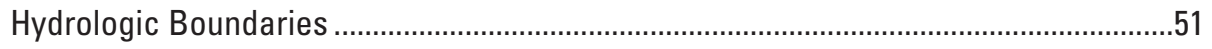

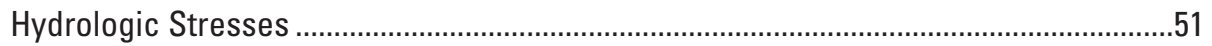

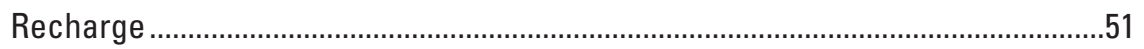

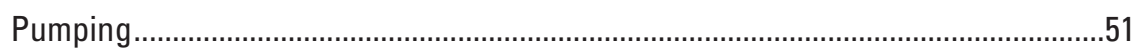

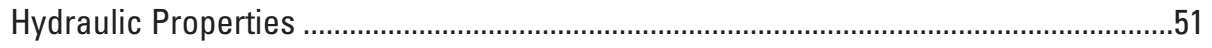

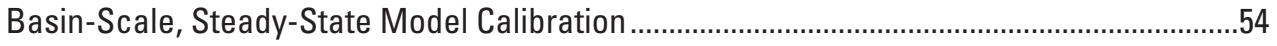

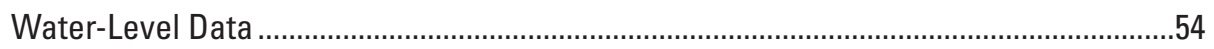

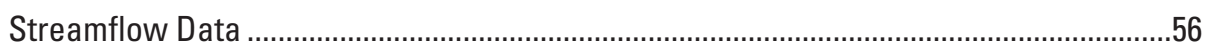

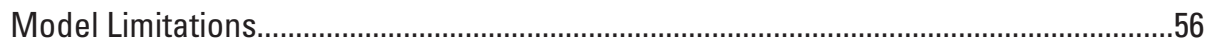

Sensitivity Analysis of Groundwater-Flow Models ..............................................................56

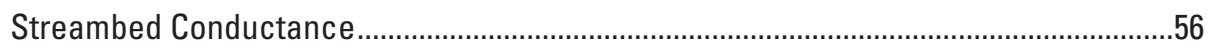

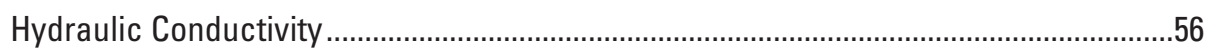

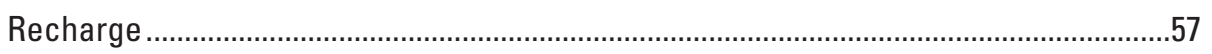

Delineation of Areas Contributing Recharge to Production Wells ..............................................57

Simulated Groundwater Levels and Drawdown................................................................57

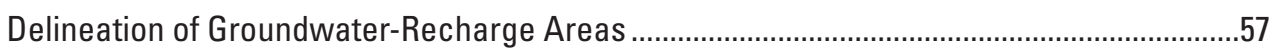

Sensitivity Analysis of Groundwater Recharge Areas ......................................................59

Streambed Conductance ................................................................................................5

Hydraulic Conductivity .............................................................................................64

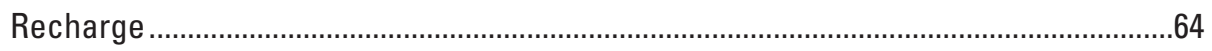

Simulation of the Interaction between Groundwater and Surface Water ......................................64

Sensitivity Analysis of Simulated Groundwater Levels ........................................................64

Sensitivity Analysis of Stream Base Flow in the Pootatuck River ..........................................66

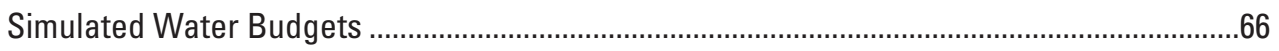

Simulated Effect of Future Recharge Conditions .........................................................................70

Base Flows in the Main Stem Pootatuck River—Future Scenarios .....................................70

Water Budgets in Subbasins of Pootatuck River-Future Scenarios .....................................70

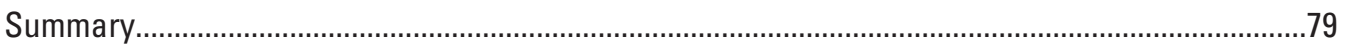

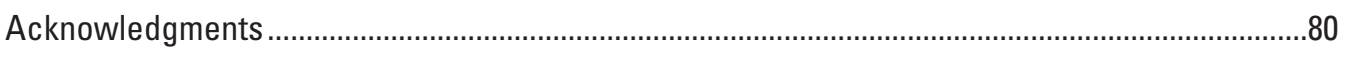

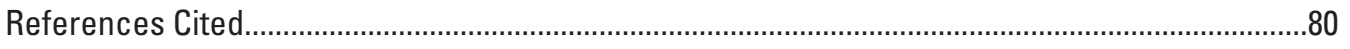

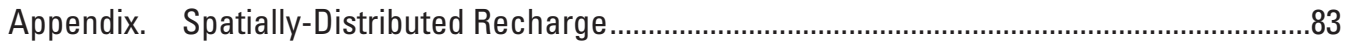




\section{Figures}

1. Map showing location of study area, Pootatuck River Basin, Newtown, Connecticut....3

2. Block diagram showing a typical glaciated bedrock valley in the northeastern United States with coarse-grained valley-fill deposits

3. Map showing bedrock surface underlying the Pootatuck River Basin, Newtown, Connecticut.

4. Map showing surficial geologic materials in the Pootatuck River Basin, Newtown, Connecticut, generalized for this study...

5. Map showing location of observation wells, piezometers, and local streamflowmeasuring sites near Fairfield Hills well field, Pootatuck River Basin, Newtown, Connecticut.

6. Map showing location of observation wells, piezometers, and local streamflow-measuring sites near United Water well field, Pootatuck River Basin, Newtown, Connecticut

7. Hydrograph of water levels in Well NT-15, Pootatuck River Basin, Newtown, Connecticut.

8. Hydrograph of stream stage recorded at the Berkshire streamgage, water levels in Wells NT-107 and NT-91, and precipitation recorded in the onsite rain gage,

Fairfield Hills well field, Pootatuck River Basin, Newtown, Connecticut.

9. Graph showing streamflow measured upstream and downstream from Well 3,

Pootatuck River Basin, Newtown, Connecticut.

10. Graph showing streamflow measured upstream and downstream from Well 7, Pootatuck River Basin, Newtown, Connecticut.

11. Graphs showing water-level measurements of surface water and groundwater in A, upstream; B, middle; and C, downstream piezometers near Well 3, Pootatuck River Basin, Newtown, Connecticut.

12. Graphs showing water-level measurements of surface water and groundwater in A, upstream; B, middle; and C, downstream piezometers near Well 7, Pootatuck River Basin, Newtown, Connecticut.

13. Graphs showing groundwater temperatures in streambed piezometers SBP7ds (downstream) and SBP7us (upstream) from Well 7, Pootatuck River Basin, Newtown, Connecticut.

14. Graphs showing groundwater temperatures in streambed piezometers SBP3ds (downstream) and SBP3us (upstream) from Well 3, Pootatuck River Basin, Newtown, Connecticut.

15. Graphs showing relation between sulfate: chloride mass ratios and $A$, depth below ground surface and $B$, isotope values of delta hydrogen-2 $(\mathbf{\delta} 2 \mathrm{H})$ in groundwater and surface water in the Pootatuck River Basin, Newtown, Connecticut.

16. Graph showing isotope values of delta oxygen-18 as a function of delta hydrogen-2 for samples of groundwater and surface water in the Pootatuck River Basin, Newtown, Connecticut.

17. Graph showing pretest water levels in observation wells A, NT-106 and B, NT-107 near

Well 3, Fairfield Hills well field, Pootatuck River Basin, Newtown, Connecticut.

18. Graph showing pumping rate in Well 2, United Water well field, Pootatuck River Basin, Newtown, Connecticut.

19. Graph showing water levels in observation well TW-6, United Water well field, Pootatuck River Basin, Newtown, Connecticut. 
20. Graph showing continuous groundwater levels and stream stage at piezometer SBP2C, United Water well field, Pootatuck River Basin, Newtown, Connecticut

21. Graphs showing stage in the Pootatuck River near at local stream flow-measuring sites Well 2 during aquifer test, Pootatuck River Basin, Newtown, Connecticut.

22. Graphs showing temperature recorded in streambed piezometers at location $B$ near Well $2 A$, P2Blb (left bank) and B, P2Brb (right bank), Pootatuck River Basin, Newtown, Connecticut.

23. Graphs showing groundwater temperature recorded in streambed piezometers at location D near Well $2 A$, P2Dlb (left bank) and B, P2Drb (right bank), Pootatuck River Basin, Newtown, Connecticut.

24. Map with transects showing extent of well-field- and basin-scale models in the Pootatuck River Basin, Newtown, Connecticut

25. Cross sections showing model layers, Pootatuck River Basin, Newtown, Connecticut

26. Map showing Fairfield Hills well-field-scale model, Pootatuck River Basin, Newtown, Connecticut

27. Map showing hydraulic conductivity in the Fairfield Hills well-field-scale model, Pootatuck River Basin, Newtown, Connecticut

28. Graphs showing simulated and observed water levels during Fairfield Hills aquifer test at Well 3, Pootatuck River Basin, Newtown, Connecticut.

29. Graphs showing simulated and observed water levels during Fairfield Hills aquifer test at Well 7, Pootatuck River Basin, Newtown, Connecticut.

30. Scatterplots showing comparison of simulated and observed water levels at Fairfield Hills and United Water well fields, Pootatuck River Basin, Newtown, Connecticut; $A$, simulated residuals compared to simulated water levels, and $B$, observed water levels

31. Map showing United Water well-field-scale model, Pootatuck River Basin, Newtown, Connecticut.

32. Map showing hydraulic conductivity in the United Water well-field-scale model, Pootatuck River Basin, Newtown, Connecticut

33. Graphs showing simulated and observed water levels during United Water aquifer test, Pootatuck River Basin, Newtown, Connecticut.

34. Map showing simulated hydraulic conductivity of the basin-scale model, Pootatuck River Basin, Newtown, Connecticut

35. Map showing areal distribution of recharge used in the basin-scale groundwater-flow model, Pootatuck River Basin, Newtown, Connecticut.

36. Scatterplots showing comparison of simulated and observed water levels in the basin-scale model A, simulated residuals compared to simulated water levels and B, observed compared to simulated water levels, Pootatuck River Basin, Newtown, Connecticut.

37. Map showing drawdown caused by simulated production wells in the Pootatuck River Basin, Newtown, Connecticut.

38. Map showing simulated areas contributing recharge to production wells in the well-field-scale models, Pootatuck River Basin, Newtown, Connecticut..

39. Map showing simulated areas contributing recharge to production wells using Level $A$ mapping regulations in the well-field-scale models, Pootatuck River Basin, Newtown, Connecticut

40. Map showing combination of simulated recharge areas resulting from the sensitivity simulations, Pootatuck River Basin, Newtown, Connecticut. 
41. Scatterplot showing comparison of simulated and observed water levels in the basin-scale model sensitivity analysis, Pootatuck River Basin, Newtown,

Connecticut.

42. Graph showing cumulative downstream base flow in the Pootatuck River in basin-scale model sensitivity analysis, Newtown, Connecticut.....

43. Map showing model subbasins in the basin-scale model, Pootatuck River Basin, Newtown, Connecticut.

44. Map showing difference in recharge in commercial land-use scenario as compared to the calibrated model, Pootatuck River Basin, Newtown, Connecticut......71

45. Graph showing cumulative downstream base flow in the Pootatuck River for the basin-scale model future-recharge analysis, Newtown, Connecticut

\section{Tables}

1. Construction details of production wells, Fairfield Hills well field, Pootatuck River Basin, Newtown, Connecticut.

2. Pumping rates for Wells 3 and 7 during Fairfield Hills aquifer test, Pootatuck River Basin, Newtown, Connecticut.

3. Stage and discharge measurements at local streamflow-measuring sites, Pootatuck River near Fairfield Hills well field, Newtown, Connecticut.

4. General chemical characteristics and concentrations of chloride and sulfate, sulfate:chloride mass ratios, and stable isotope values for $\delta^{2} \mathrm{H}$ and $\delta^{18} 0$ in the Pootatuck River Basin, Newtown, Connecticut.

5. Results of mixing models estimated using isotope values for $\boldsymbol{\delta}^{2} \mathrm{H}$ and $\boldsymbol{\delta}^{18} 0$ in river and groundwater samples in the Pootatuck River Basin, Newtown, Connecticut.

6. Observed and corrected drawdowns in observation wells, Fairfield Hills well field, Pootatuck River Basin, Newtown, Connecticut.

7. Transmissivity and hydraulic conductivity calculated from aquifer tests, Pootatuck River Basin, Newtown, Connecticut.

8. Construction details of production wells, United Water well field, Pootatuck River Basin, Newtown, Connecticut.

9. Calibrated hydraulic parameters of the Fairfield Hills well-field-scale model, Pootatuck River Basin, Newtown, Connecticut.

10. Simulated and observed water levels in wells at the Fairfield Hills well field, Pootatuck River Basin, Newtown, Connecticut.

11. Simulated and observed base flow, Fairfield Hills well field, Pootatuck River Basin, Newtown, Connecticut.

12. Calibrated hydraulic parameters of the United Water well-field-scale model, Pootatuck River Basin, Newtown, Connecticut.

13. Simulated and observed water levels in wells at the United Water well field, Pootatuck River Basin, Newtown, Connecticut.

14. Registered pumping rates and distance from stream for all production wells in the basin-scale model, Pootatuck River Basin, Newtown, Connecticut

15. Source of water to production wells, Pootatuck River Basin, Newtown, Connecticut..59

16. Results of the sensitivity analyses on recharge areas for the well-field-scale models, Pootatuck River Basin, Newtown, Connecticut.....

17. Results of sensitivity analysis on water levels in the basin-scale model, Pootatuck River Basin, Newtown, Connecticut. 
18. Annual water budget for modeled subbasins under pumping and nonpumping conditions, Pootatuck River Basin, Connecticut.

19. Cumulative base flow in future pumping scenarios, Pootatuck River Basin, Newtown, Connecticut.

20. Base flow from individual subbasins in future pumping scenarios, Pootatuck River Basin, Newtown, Connecticut.

21. Coefficients and statistics for regression equation to determine groundwater recharge, Pootatuck River Basin, Newtown, Connecticut 


\section{Conversion Factors and Datum}

Inch/Pound to SI

\begin{tabular}{|c|c|c|}
\hline Multiply & By & To obtain \\
\hline \multicolumn{3}{|c|}{ Length } \\
\hline inch (in.) & 2.54 & centimeter $(\mathrm{cm})$ \\
\hline foot $(\mathrm{ft})$ & 0.3048 & meter $(\mathrm{m})$ \\
\hline mile (mi) & 1.609 & kilometer (km) \\
\hline \multicolumn{3}{|c|}{ Area } \\
\hline square mile $\left(\mathrm{mi}^{2}\right)$ & 2.590 & square kilometer $\left(\mathrm{km}^{2}\right)$ \\
\hline \multicolumn{3}{|c|}{ Volume } \\
\hline gallon (gal) & 3.785 & liter (L) \\
\hline gallon (gal) & 0.003785 & cubic meter $\left(\mathrm{m}^{3}\right)$ \\
\hline million gallons (Mgal) & 3,785 & cubic meter $\left(\mathrm{m}^{3}\right)$ \\
\hline cubic foot $\left(\mathrm{ft}^{3}\right)$ & 0.02832 & cubic meter $\left(\mathrm{m}^{3}\right)$ \\
\hline \multicolumn{3}{|c|}{ Flow rate } \\
\hline cubic foot per second $\left(\mathrm{ft}^{3} / \mathrm{s}\right)$ & 0.02832 & cubic meter per second $\left(\mathrm{m}^{3} / \mathrm{s}\right)$ \\
\hline cubic foot per day $\left(\mathrm{ft}^{3} / \mathrm{d}\right)$ & 0.02832 & cubic meter per day $\left(\mathrm{m}^{3} / \mathrm{d}\right)$ \\
\hline gallon per minute (gal/min) & 0.06309 & liter per second $(\mathrm{L} / \mathrm{s})$ \\
\hline gallon per day (gal/d) & 0.003785 & cubic meter per day $\left(\mathrm{m}^{3} / \mathrm{d}\right)$ \\
\hline million gallons per day (Mgal/d) & 0.04381 & cubic meter per second $\left(\mathrm{m}^{3} / \mathrm{s}\right)$ \\
\hline inch per year (in/yr) & 25.4 & millimeter per year (mm/yr) \\
\hline \multicolumn{3}{|c|}{ Hydraulic conductivity } \\
\hline foot per day $(\mathrm{ft} / \mathrm{d})$ & 0.3048 & meter per day $(\mathrm{m} / \mathrm{d})$ \\
\hline \multicolumn{3}{|c|}{ Transmissivity* } \\
\hline foot squared per day $\left(\mathrm{ft}^{2} / \mathrm{d}\right)$ & 0.09290 & meter squared per day $\left(\mathrm{m}^{2} / \mathrm{d}\right)$ \\
\hline
\end{tabular}

Temperature in degrees Celsius $\left({ }^{\circ} \mathrm{C}\right)$ may be converted to degrees Fahrenheit $\left({ }^{\circ} \mathrm{F}\right)$ as follows:

$$
{ }^{\circ} \mathrm{F}=\left(1.8 x^{\circ} \mathrm{C}\right)+32
$$

Temperature in degrees Fahrenheit $\left({ }^{\circ} \mathrm{F}\right)$ may be converted to degrees Celsius $\left({ }^{\circ} \mathrm{C}\right)$ as follows:

$$
{ }^{\circ} \mathrm{C}=\left({ }^{\circ} \mathrm{F}-32\right) / 1.8
$$

Vertical coordinate information is referenced to the National Geodetic Vertical Datum of 1929 (NGVD29).

Horizontal coordinate information is referenced to the North American Datum of 1983 (NAD 83).

Altitude, as used in this report, refers to distance above the vertical datum.

*Transmissivity: The standard unit for transmissivity is cubic foot per day per square foot

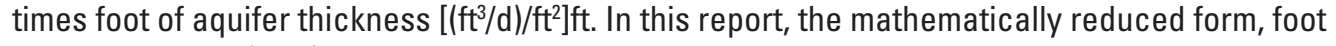
squared per day $\left(\mathrm{ft}^{2} / \mathrm{d}\right)$, is used for convenience.

Specific conductance is given in microsiemens per centimeter at 25 degrees Celsius $(\mu \mathrm{S} / \mathrm{cm}$ at $\left.25^{\circ} \mathrm{C}\right)$.

Concentrations of chemical constituents in water are given either in milligrams per liter (mg/L) or micrograms per liter $(\mu \mathrm{g} / \mathrm{L})$. 



\title{
Hydrogeology and Numerical Simulation of the Unconsolidated Glacial Aquifer in the Pootatuck River Basin, Newtown, Connecticut
}

\author{
By Carl S. Carlson, Remo A. Mondazzi, David M. Bjerklie, and Craig J. Brown
}

\section{Abstract}

A study of the groundwater and stream-aquifer interaction in the Pootatuck River Basin, Newtown, Connecticut, was conducted to analyze the effect of production wells on the groundwater levels and streamflow in the Pootatuck River as part of a cooperative program between the U.S. Geological Survey and Newtown, Connecticut. This study will help address concerns about the increasing competition for water for human uses and protection of aquatic habitat. The groundwater-flow model developed in the study was designed for use as a tool to assist planners in assessing the effects of potential future development, which will change the amount and distribution of recharge available to the groundwater system.

Several different techniques were used to investigate the interconnection between the stream and the aquifer. Temperature, groundwater levels, stream stage, and stableisotope data collected during aquifer tests at the principal production wells in the Pootatuck River Basin, as well as groundwater-flow simulations of the system, indicate that more than half of the water pumped from the wells comes from the Pootatuck River. This finding potentially has a large effect on approaches for protecting the water quality of the pumped water. Increases in the amount of impervious surface from future development will reduce and redistribute recharge to the groundwater system. The simulation of future development scenarios showed a decrease in the simulated base flow in the main stem of the Pootatuck River and in all of the 26 simulated subbasins, with some of the subbasins showing a decrease of more than 20 percent when new development had 85 percent impervious area.

The groundwater-flow model and particle tracking were used to determine areas that contribute recharge to the five production wells available for use in the Pootatuck River Basin. These areas included narrow portions of the aquifer that extended beyond the immediate upgradient areas, probably because of deeper groundwater-flow paths.

\section{Introduction}

The Pootatuck aquifer, located entirely in Newtown, Connecticut, was designated by the U.S. Environmental Protection Agency as a Sole Source Aquifer and in 2007 supplied water for about 3,000 residents of Newtown. Protection of water quality in production wells is a major concern of Newtown and the Connecticut Department of Environmental Protection (CTDEP). Also they are concerned about potential competition for water between increasing groundwater withdrawals and instream-flow requirements to sustain aquatic habitats, particularly during base flows when all the flow is groundwater discharging to streams. In order to manage the aquifer and river as a single system, it is important to quantitatively account for effects of withdrawals by simulating interactions between groundwater and surface water.

Newtown and CTDEP also are concerned about the possible effect that land-use change from development might have on recharge to the Pootatuck aquifer and thereby the base flow in the Pootatuck River, and the increased potential for spills and leaks that could contaminate the aquifer and groundwater supplies. Recent studies by the U.S. Geological Survey (USGS) in the nearby Pomperaug River Basin have shown that land-use change does affect recharge, and that the change can be quantified (Bjerklie and others, in press). Newtown and the public are interested in developing a scientific understanding of the aquifer and its interaction with the Pootatuck River so that appropriate land- and water-use management strategies can be implemented. In response to these concerns, in 2006, the USGS and Newtown entered into a cooperative agreement to study the hydrology of the area. An important product from this study is a basin-wide model that incorporates an estimate of areally-distributed recharge. This model can be used to assess the effect of decreased groundwater recharge to the aquifer resulting from future development.

The Connecticut Aquifer Protection Program (State of Connecticut, 1991), managed by the CTDEP, requires water suppliers to delineate aquifer-protection areas (referred to 
as "Level A mapping") for all wells that obtain water from stratified glacial deposits and that provide water to more than 1,000 people. Level A mapping makes use of groundwaterflow models to delineate the contributing area to the wells under steady-state hydrogeologic conditions. Data collected for the USGS/Newtown cooperative study could be used to satisfy the Level A mapping requirement. The aquifer tests performed for this study provided data for model calibration to estimate stream inflow (induced infiltration) from the Pootatuck River and for Level A mapping of the well fields under CTDEP regulations.

Because the Pootatuck River and the aquifer are interconnected, an important element of this study was using multiple methods of investigating the stream-aquifer interaction near production wells. Several techniques were used, including temperature and stable-isotope analysis as well as the more typical streamflow and water-level measurements. These techniques helped quantify the stream inflow and can be used in other areas in New England where production wells are adjacent to streams.

\section{Purpose and Scope}

This report describes the hydrogeologic analysis and computer modeling that was done in the Pootatuck River Basin in western Connecticut. Groundwater-flow models were used to delineate areas from which groundwater recharge moves to production wells and to provide information on the interaction between the production wells and the Pootatuck River, including estimates of stream inflow from the Pootatuck River to the aquifer at the Fairfield Hills and United Water well fields in Newtown, Connecticut. The report also describes simulated effects of possible land-use change on the distribution and amount of recharge available to the groundwater system and the associated effect on base flow in streams.

Three aquifer tests were performed as part of this study - two simultaneous tests at the Fairfield Hills well field and another at the United Water well field in Newtown, Connecticut (fig. 1). Groundwater and surface-water data from the aquifer tests were used to calibrate the groundwater-flow models and to assess the interaction between the groundwater withdrawals and surface water.

\section{Location and Description}

The Pootatuck River Basin is located in southwestern Connecticut (fig. 1). The Pootatuck River flows northward in a narrow valley in the highlands of western Connecticut. The headwaters of the Pootatuck River are in the towns of Easton and Monroe. The Pootatuck River, which drains a total of $26.1 \mathrm{mi}^{2}$, flows through Newtown and discharges into the Housatonic River. A general description of the hydrology of the lower Housatonic River Basin (the major drainage basin in which the Pootatuck River is located) is provided in the
Connecticut Department of Environmental Protection Water Resources Inventory of Connecticut series (Wilson and others, 1974).

\section{Previous Investigations}

The hydrogeology of the area was first described by Wilson and others (1974) as part of a regional study of the hydrology of the lower Housatonic River Basin. Surficial geology of the area was described by McKeegan (1986) and by Stone and others $(1992,1998)$, and the bedrock geology was described by Rodgers (1985).

Haeni (1978) conducted an investigation of the hydrogeology of the Pootatuck River aquifer that compiled information on the distribution and hydraulic properties of the stratified glacial deposits, the altitude of bedrock in the valley, streamflow characteristics, and water quality of surface water and groundwater. In addition, Haeni (1978) used a numerical model based on available data, test drilling, seismic-refraction profiling, and the stream-aquifer connection. The report presented information on the quantity of water available from the sand and gravel aquifer, predictions on the effects of withdrawing that quantity on the stream-aquifer system, and the quality of groundwater and surface water.

Grady and Weaver (1988) conducted a study of the Pootatuck River Valley as part of a regional groundwaterquality appraisal. Information was presented on the saturated thickness, the areal distribution of average horizontal hydraulic conductivity, the altitude of the water table, and water quality of the sand and gravel aquifer.

\section{Hydrogeology of the Pootatuck River Valley}

\section{Physiography and Geology}

The Pootatuck River Basin is dominated by a narrow bedrock valley, which is less than a mile wide in most places, within extensive upland areas and is typical of glaciated valleys in the northeastern part of the United States (fig. 2). The valley walls are formed by till-blanketed bedrock that reaches elevations of over $650 \mathrm{ft}$ near the confluence of the Pootatuck River with the Housatonic River. Highlands to the east and west of the valley are underlain by Paleozoic-age crystalline (metamorphic) bedrock that is predominantly dioritic gneiss of the Brookfield Gneiss (Rodgers, 1985). A bedrock-surface contour map (fig. 3) for the Pootatuck Basin was constructed using data from test-well borings, domestic-well-completion reports, locations of bedrock outcrops, a seismic-refraction survey (Haeni, 1978), and a map of stratified glacial deposits (McKeegan, 1986). Because this bedrock-surface contour map was used as the bottom of the modeled aquifer, in some areas the bedrock surface is shown as somewhat lower than 


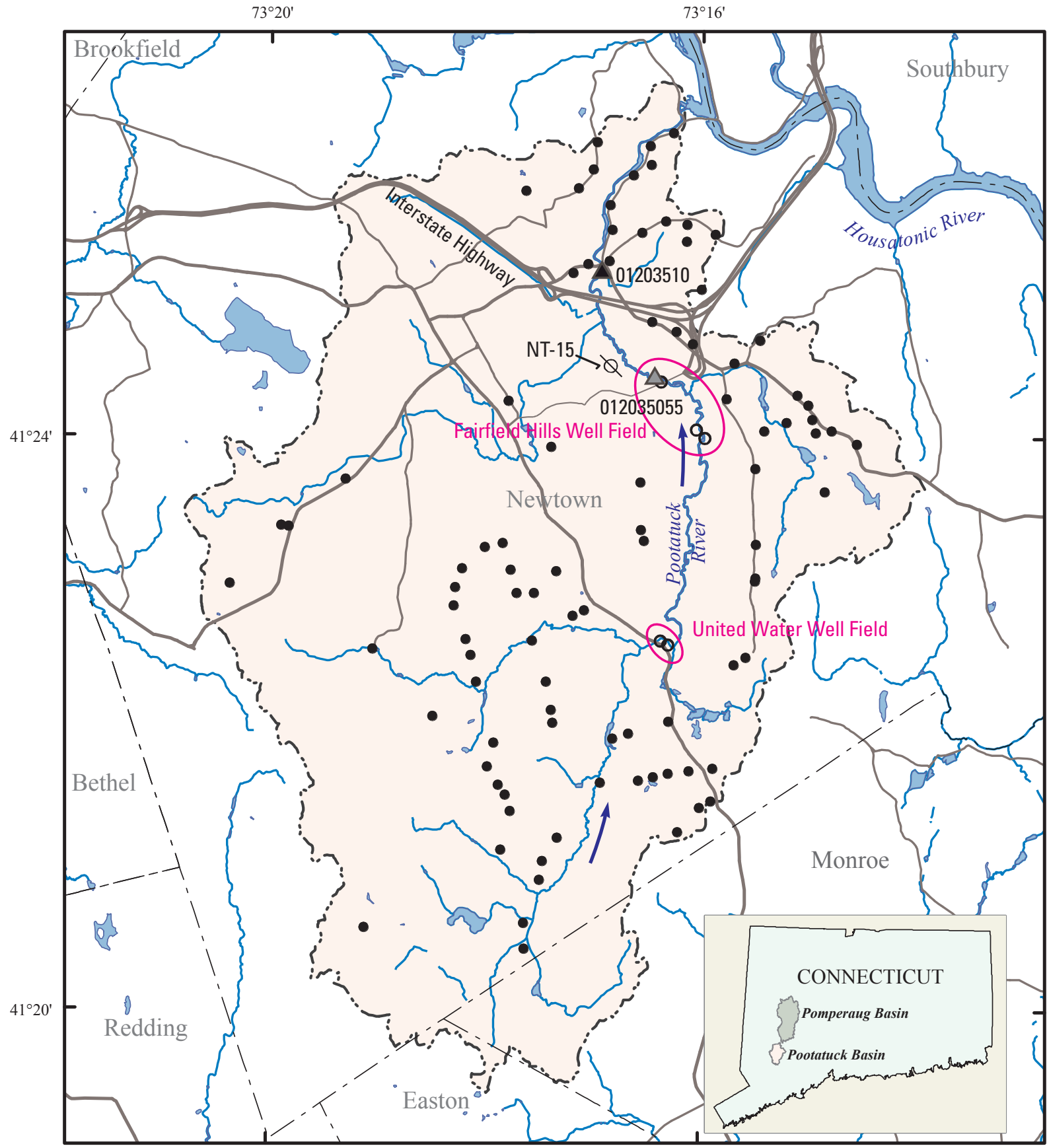

Base from Connecticut Department of Environmental Protection Digital Line Graphs, 2005

EXPLANATION

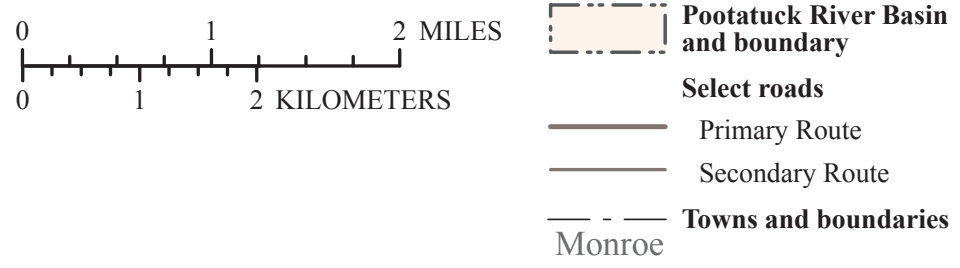

$\longleftarrow$ Flow direction
Wells, gages, and stations

- Domestic well

O Production well

$\triangle$ Continuous-record streamgage and identifier

Q Long-term groundwater-level monitoring well

Figure 1. Location of study area, Pootatuck River Basin, Newtown, Connecticut. 


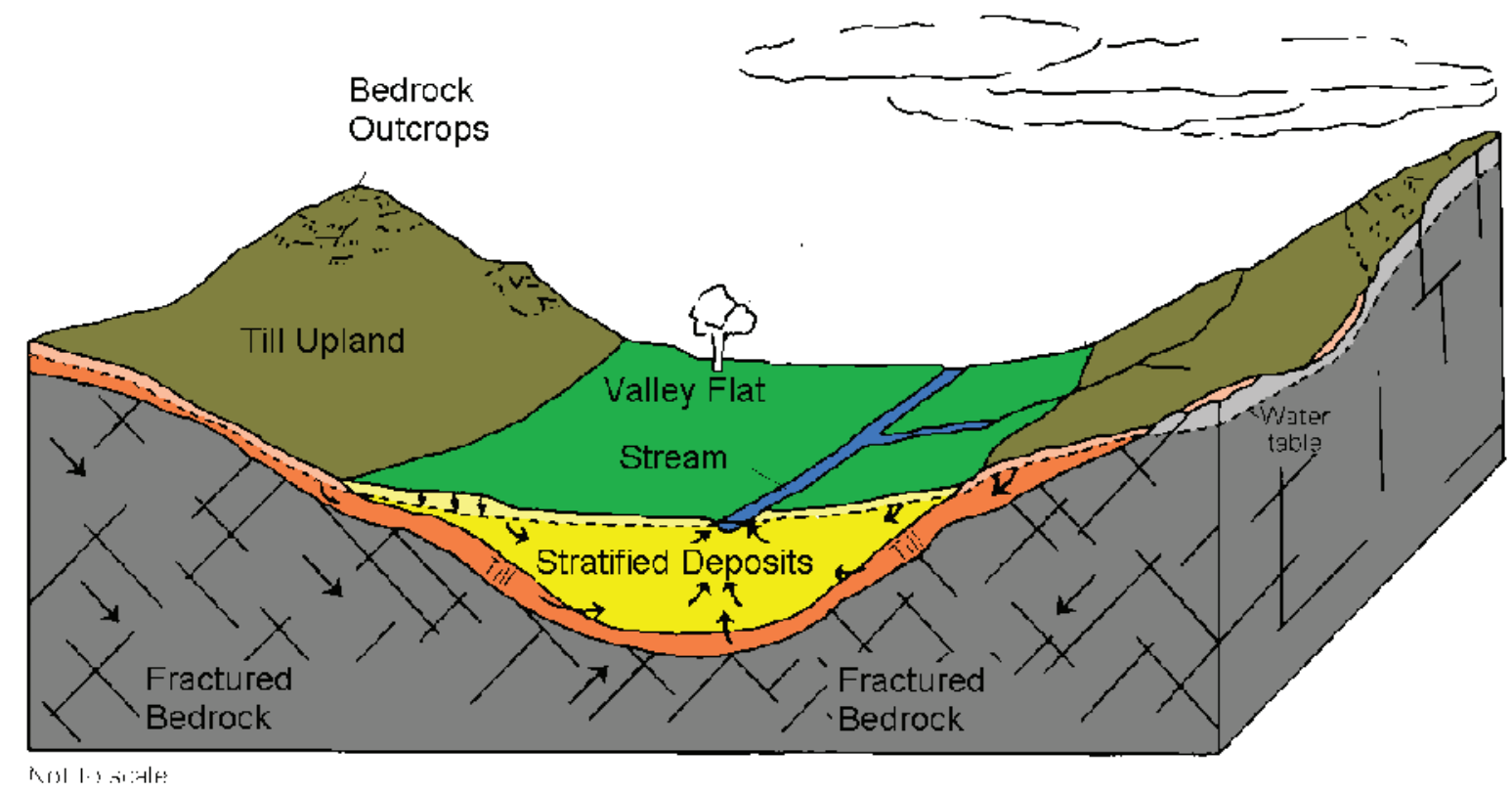

Figure 2. A typical glaciated bedrock valley in the northeastern United States with coarse-grained valley-fill deposits.

it actually is to ensure that the overlying stratified glacial deposits are at least 15 -ft thick. Also, in the upland areas, the bedrock-surface map represents land surface.

The Pootatuck River is underlain by three principal hydrogeologic units: bedrock, glacial till, and stratified glacial deposits. Surficial materials have been mapped at a regional scale (Stone and others, 1992, 1998) and include (1) glacial till, which was laid down directly by ice on top of bedrock and is the surficial material on the valley sides and in the uplands;

(2) glacial meltwater deposits, which consist of stratified sands and gravels that partially fill the bedrock valley to an altitude of approximately $300 \mathrm{ft}$; and (3) small areas of flood plain alluvium, swamp deposits, and fine-grained sediments. The till and glacial meltwater deposits were laid down during advance and retreat of Pleistocene continental glaciers, particularly during the last (late-Wisconsinan) glaciation.

\section{Description of Hydrologic Units}

The principal hydrologic units in the basin are coarsegrained stratified glacial deposits (sands and gravels); till, which is thick in some areas (more than 10-15 ft thick); swamp deposits; and bedrock. The coarse-grained sand and gravel deposits have the highest hydraulic conductivity and form the most productive aquifer that is used at the Fairfield Hills and United Water well fields (fig. 4). The bedrock aquifer provides water only to individual domestic wells. The Pootatuck River streambed is generally composed of alluvium overlying sand and gravel that provides a good hydraulic connection between the stream and underlying glacial aquifer. The average vertical hydraulic conductivity of the streambed sediments was calculated (Haeni, 1978) to be $1.9 \mathrm{ft} / \mathrm{d}$ based on laboratory-determined vertical hydraulic conductivity values of undisturbed samples that ranged from 1.3 to $3.9 \mathrm{ft} / \mathrm{d}$.

\section{Data Collection and Analysis}

\section{Methods of Data Collection}

The Pootatuck River and the underlying aquifer are interconnected. One of the objectives of this study was to explore multiple ways of determining that interconnection. Therefore, the data collected to study the hydrogeology of the Pootatuck River Basin included (1) monitoring streamflow, (2) installation of observation wells and streambed piezometers, (3) groundwater-level monitoring, (4) temperature monitoring of groundwater and surface water, (5) hydraulic (aquifer) testing of unconsolidated glacial deposits, and (6) water-quality and stable-isotope analysis of groundwater and surface water. 


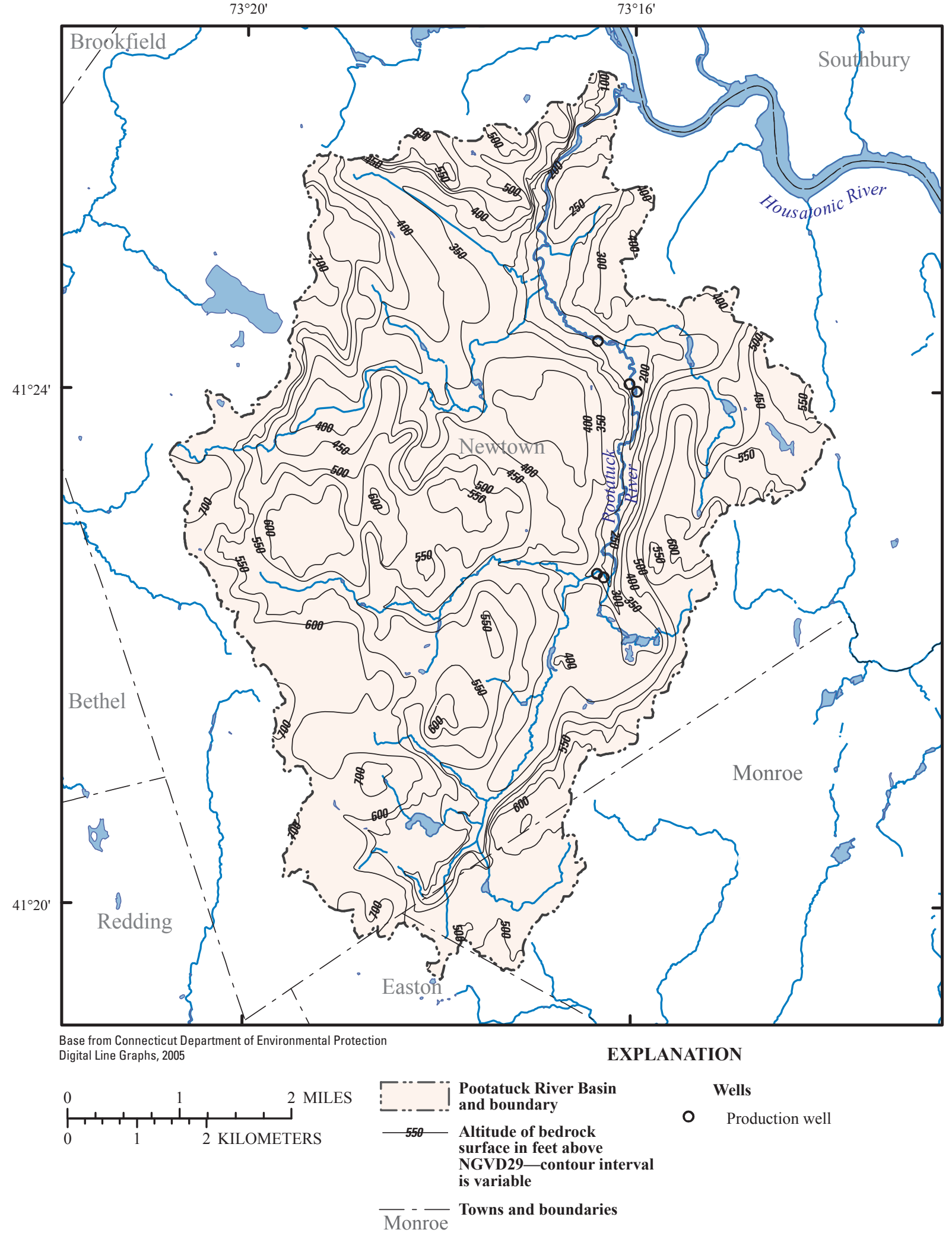

Figure 3. Bedrock surface underlying the Pootatuck River Basin, Newtown, Connecticut. 
$73^{\circ} 20^{\prime}$ $73^{\circ} 16^{\prime}$

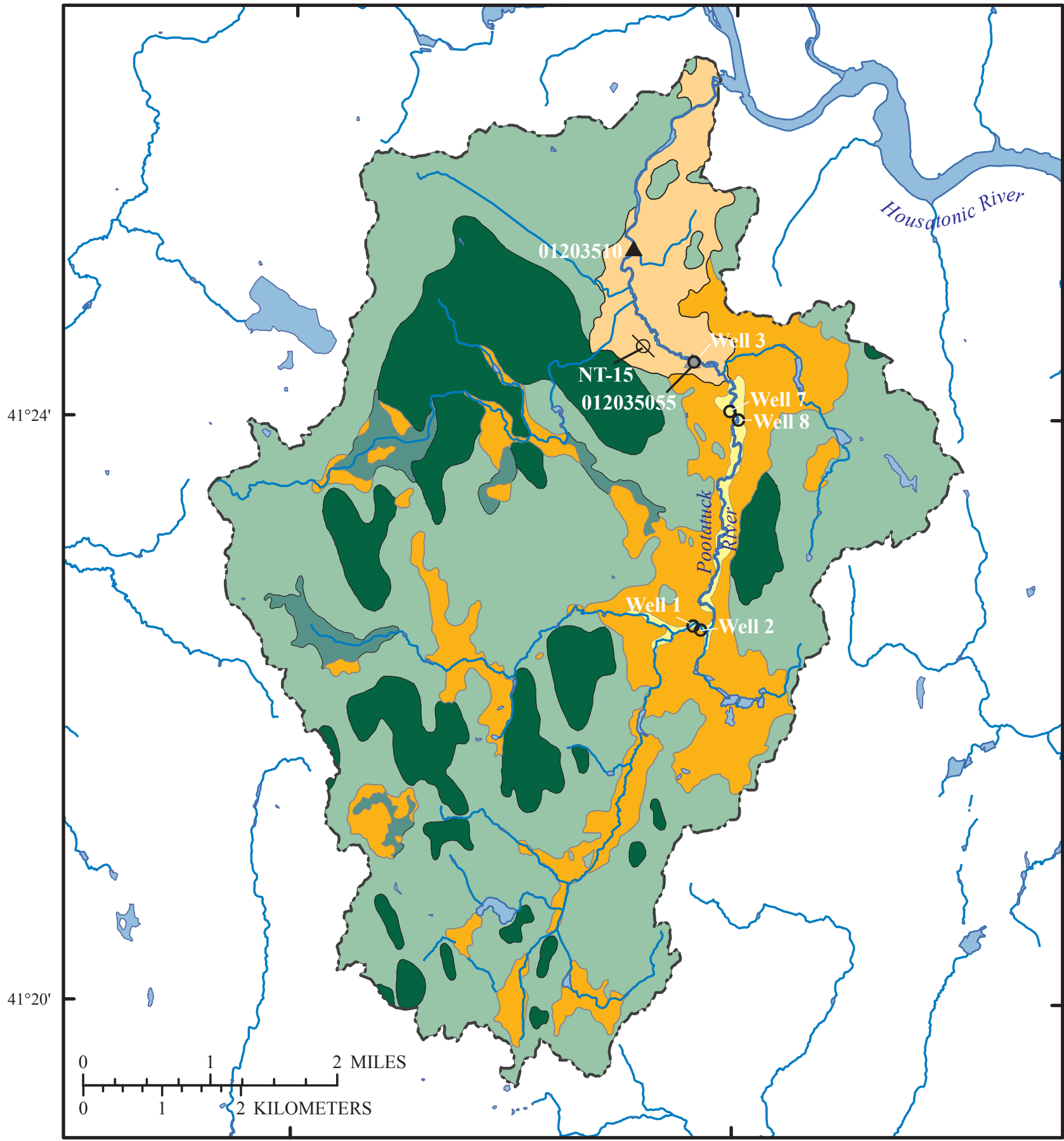

Base from Connecticut Department of Environmental Protection

Digital Line Graphs, 2005. Surficial geology modified from Stone and others, 1992

Surficial Geology

EXPLANATION
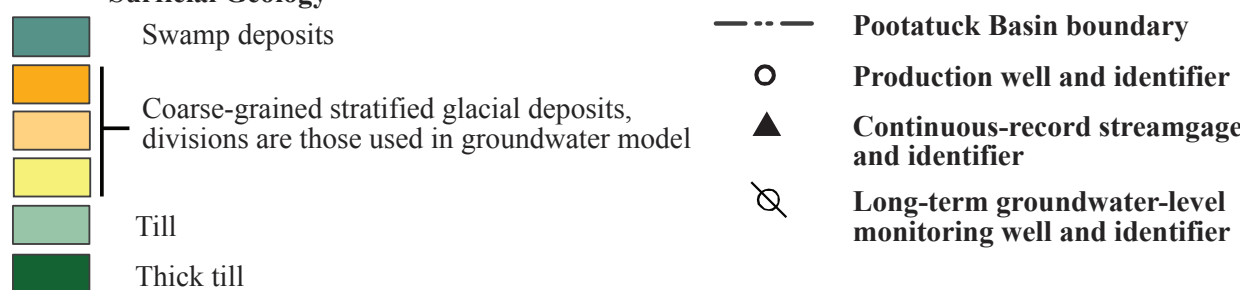

Figure 4. Surficial geologic materials in the Pootatuck River Basin, Newtown, Connecticut, generalized for this study. (Modified from Stone and others, 1992) 


\section{Streamflow}

USGS streamgage 01203510 - Pootatuck River at Sandy Hook - was reactivated for this study (previously in operation from 1965 through 1973), and a second streamgage, 012035055—Pootatuck River at Berkshire—was installed near Well 3 of the Fairfield Hills well field (fig. 1). These streamgages provided data for the basin as a whole and were used to calibrate the groundwater-flow models. During the course of this study, data from the Sandy Hook streamgage were used to verify that prior streamflow data could be used to represent current conditions.

Temporary staff gages were installed in the Pootatuck River at local streamflow-measuring sites upstream and downstream from the anticipated area of influence of each production well (figs. 5 and 6). Streamflow measurements were made at these sites before, during, and after the aquifer tests, and a rating curve for each site was developed to facilitate determining streamflow during the test. Stage measurements were recorded frequently throughout the test. However, poor site conditions, such as a cobble streambed and backwater from a beaver pond, and the short distance between the measuring sites precluded accurately quantifying streamflow gain or loss over each reach.

\section{Observation Wells and Streambed Piezometers}

Five 2-in. inside diameter (ID) observation wells with 2- or 3-ft screens had been installed at the Fairfield Hills well field for previous studies; these observation wells (NT-85, NT-86, NT-90, NT-91 and NT-94, fig. 5), are all near Well 7. Because there were no existing observation wells near Well 3, in September 2006, five 2-in. ID observation wells with 10-ft screens were drilled by Soiltesting, Inc., using a hollow-stem auger (Wells NT-106 to NT-110). Wells NT-108 and NT-109 are at different depths at almost the same location (fig. 5). These wells were used to determine the depth to bedrock, altitude of the water table, and distribution of geologic units in the vicinity of Fairfield Hills Well 3. At the United Water well field, six 2-in. ID observation wells had been installed near Well 2 for previous studies (TW-1 to TW-6); however, only three were available for use in the current study (TW-2, TW-4, and TW-6, fig. 6). At the start of the current study, all observation wells were developed through a combination of surging and pumping and were tested for hydraulic connection with the aquifer by introducing a slug of water into each well and verifying that the water level returned to static conditions.

Three 1.25-in. ID streambed piezometers were installed in the Pootatuck River in 2006 near each of Fairfield Hills Wells 3 and 7 (SBP3us, SBP3ms, and SBP3ds, and SBP7us, SBP7ms, and SBP7ds; us, ms, and ds are upstream, middle, and downstream, respectively, fig. 5). Six piezometers were installed near United Water Well 2 (SBP2A, SBP2Blb, SBP2Brb, SBP2C, SBP2Dlb and SBP2Drb; rb and lb are right and left bank, respectively, fig. 6). The piezometers were used to monitor groundwater and surface-water levels, measure groundwater and surface-water temperatures, and to aid in quantifying stream inflow. The piezometers were installed by hand, using a post driver and sledge hammer, until the bottom of the 0.25 - $\mathrm{ft}$ screen was $6 \mathrm{ft}$ below the streambed. Prior to making water-level measurements, all piezometers were developed by continuously surging and pumping until the water flowed clear. The streambed piezometers and the wells were used as observation wells during the aquifer test period.

\section{Groundwater-Level Monitoring}

Two methods were used to monitor water levels: (1) periodic, manual water-level measurements were made using an electric tape, and (2) continuous water-level measurements were made with pressure transducers. From January 1 to September 5, 2007, water levels from outside the area of influence of the production wells were measured continuously in Well NT-15, which is part of the USGS longterm, groundwater-level-monitoring network (fig. 1).

\section{Temperature Monitoring}

Differences between temperatures of water in the stream and in surrounding sediments can indicate whether water flows to or from streams (Stonestrom and Constantz, 2003). Groundwater temperature was monitored in two stream piezometers at each of the production-well locations. Hobo U12, four-channel temperature loggers with water/soil temperature sensors were secured to 0.25 -in. plastic tubing placed inside the piezometers and set at $0,2,4$, and $6 \mathrm{ft}$ below the streambed, following procedures described in Stonestrom and Constantz (2003). Logging rates were set at 1-hour intervals prior to the aquifer tests and at 1-minute intervals during the tests. Temperature of the discharge water from each production well also was monitored manually using a glass thermometer. Several times a day, samples from an in-line faucet were collected in a sample bottle and the temperature was immediately recorded.

\section{Aquifer Test}

The purpose of an aquifer test is to determine properties of the aquifer by collecting groundwater-level data under controlled pumping conditions and analyzing them to determine the transmissivity and storage coefficients of the aquifer. A typical aquifer test has three parts: (1) a period of no pumping that allows water levels to recover to nonpumping (static) levels, (2) the pump(s) run until the water level in the vicinity of the production well has stabilized, and (3) a recovery period in which water levels are monitored until they approach static levels. Ideally, the pumps should run at a constant rate and there should be no rainfall before or during the test. Because data from the aquifer tests in the present study will be used for Level A mapping, additional guidelines and regulations were specified by CTDEP (State of Connecticut, 1991). However, 


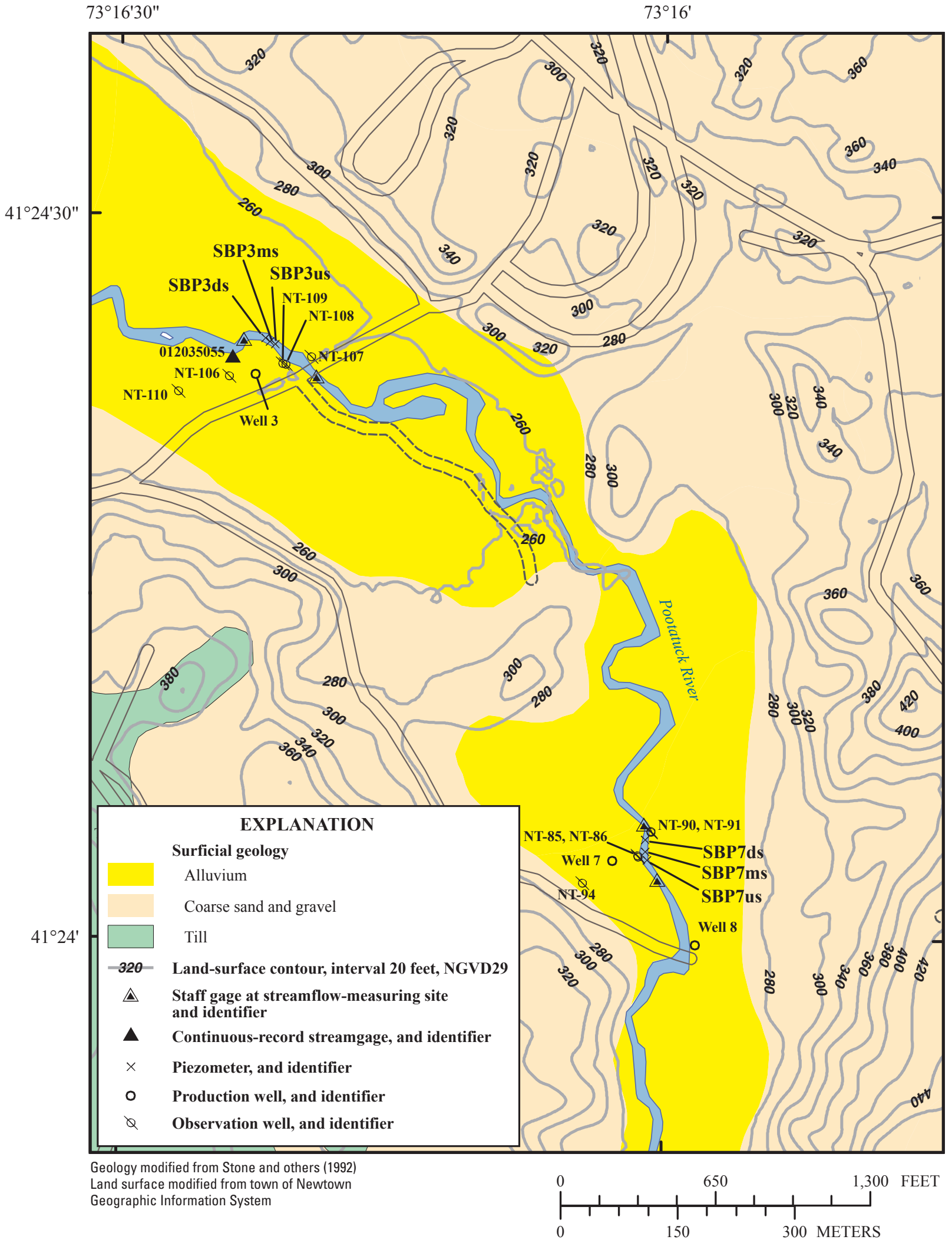

Figure 5. Location of observation wells, piezometers, and local streamflow-measuring sites near Fairfield Hills well field, Pootatuck River Basin, Newtown, Connecticut. 


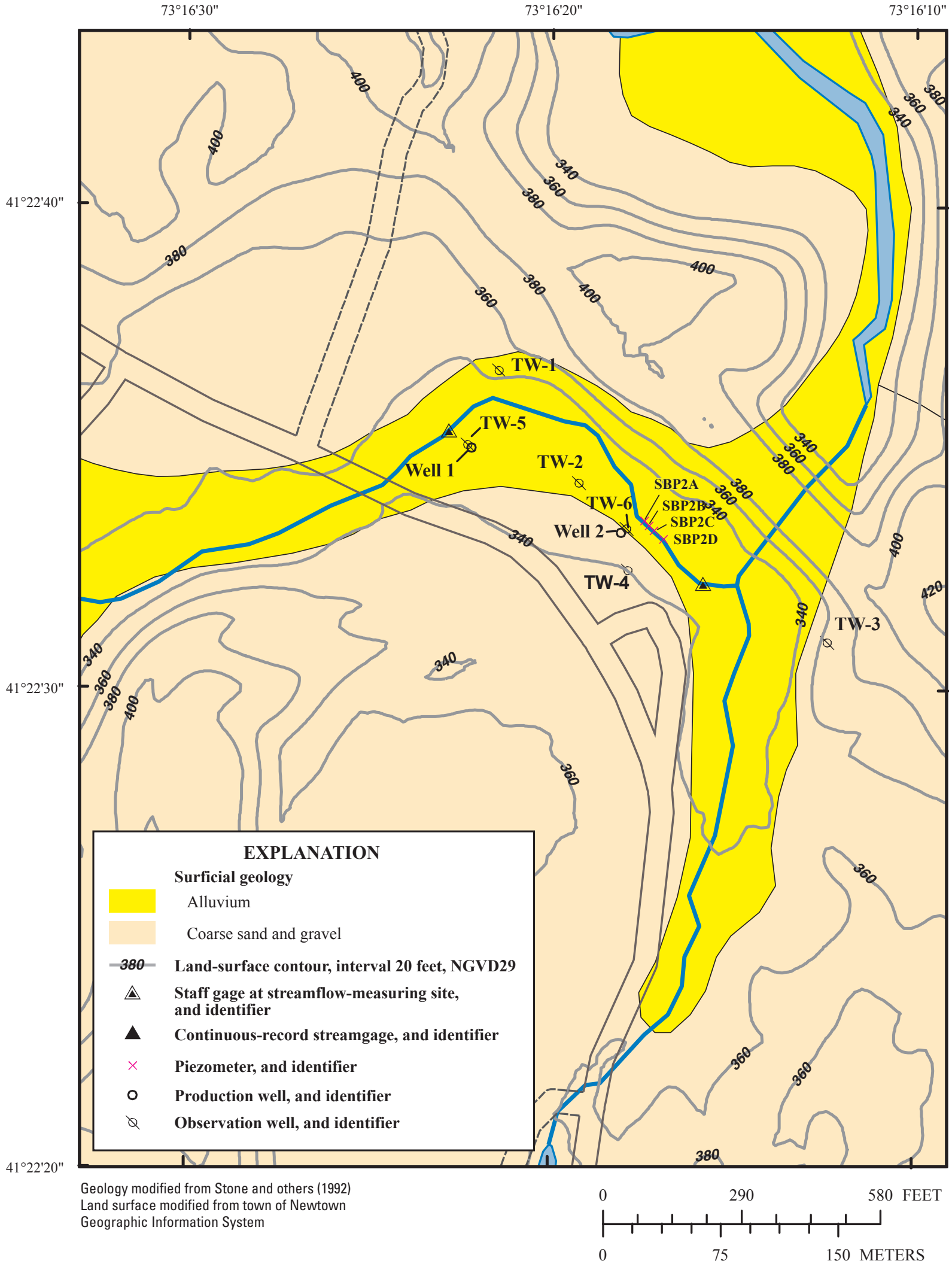

Figure 6. Location of observation wells, piezometers, and local streamflow-measuring sites near United Water well field, Pootatuck River Basin, Newtown, Connecticut. 
it was not possible to conduct the aquifer tests following these guidelines because of constraints imposed by the needs of the water-supply system and by uncontrollable natural events.

Calculations of transmissivity were done for the well fields using the distance-drawdown method described by Cooper and Jacob (1946) using spreadsheets developed by the USGS (Halford and Kuniansky, 2002). The Cooper-Jacob distance-drawdown method is typically used for confined conditions but can be applied to unconfined aquifers after drawdown data are corrected for partial penetration as described by Cooper and Jacob (1946) and Kruseman and DeRidder (1990). Further analysis was done with a numerical model to fully incorporate boundary conditions and test a range of storage coefficients.

\section{Water-Quality and Stable-Isotope Analysis}

Water quality and stable isotopes were used to quantify the amount of water moving from the Pootatuck River into the aquifer in the vicinity of the production wells. During aquifer tests on Fairfield Hills Wells 3 and 7, water from the production wells, three observation wells, and the Pootatuck River was monitored for field parameters, including temperature, $\mathrm{pH}$, and specific conductance, and water-quality samples were collected. Observation wells NT-85 and NT-86 are between Well 7 and the river, and observation well NT-94 is upgradient from Well 7 and represents ambient groundwater (fig. 5). The samples were analyzed for chloride and sulfate. In addition, the normalized stable-isotope ratios of oxygen- 18 to oxygen-16 (delta oxygen- 18 or $\delta^{18} \mathrm{O}$ ) and hydrogen-2

(also known as deuterium) to hydrogen-1 (delta hydrogen-2 or $\left.\delta^{2} \mathrm{H}\right)$ were determined. Surface-water samples were collected from the Pootatuck River adjacent to Well 7 by filling the sample bottles below the water surface. Groundwater samples were collected from Wells 3 and 7 and observation wells NT-85, NT-86, and NT-94. Prior to groundwater-sample collection, wells were purged with a peristaltic pump and field parameters were monitored until stable. (The amount of water removed did not affect the water levels used for the aquifertest analysis.)

The USGS National Water-Quality Laboratory in Denver, Colorado, analyzed the water samples for chloride and sulfate by ion chromatography, as described by Fishman and Friedman (1989). Analysis of the normalized stable-isotope ratios of oxygen and hydrogen found in water was done at the USGS Reston Stable-Isotope Laboratory in Reston, Virginia; $\delta^{2} \mathrm{H}$ analysis was done using a hydrogen equilibration method (Coplen and others, 1991), and $\delta^{18} \mathrm{O}$ analysis was done using a $\mathrm{CO}_{2}$ equilibration technique (Epstein and Mayeda, 1953). The $\delta^{2} \mathrm{H}$ and $\delta^{18} \mathrm{O}$ isotopic results are reported in per mil relative to Vienna Standard Mean Ocean Water (VSMOW) and normalized (Coplen, 1994) on scales such that the oxygen and hydrogen isotopic values of Standard Light Antarctic Precipitation are -55.5 per mil and -428 per mil, respectively.

\section{Fairfield Hills Well Field}

\section{Site Description}

The Fairfield Hills system was formerly known as the Fairfield Hills Hospital system and was owned and operated by the Connecticut Department of Mental Retardation. The hospital facilities were closed in 1997 and Newtown acquired the property and production wells. Three wells identified as Well 3, Well 7, and Well 8 (fig. 5) withdraw water from a stratified glacial aquifer that is more than $100-\mathrm{ft}$ thick in places (table 1). Well 8 serves as a backup and typically is pumped only once per quarter for water-quality samples in order to maintain an active status as required by the Connecticut Department of Public Health.

\section{Pumping Information}

The groundwater pumping rates registered as a diversion with CTDEP for the production wells are shown in table 1. Substantial improvements were made to Well 3 in 2006 and to Well 7 in 2001. Improvements to Well 8 (the reserve well) are planned for some time in the future. Prior to the improvements, Wells 3 and 7 operated together as an on-demand system - the wells turn on automatically when the storage drops below a specified level—producing 120,000 to $150,000 \mathrm{gal} / \mathrm{d}$ (Jason O'Brian, Aquarion Operating Services, oral commun., 2006); after the improvements, Wells 3 and 7 began operating independently and together produce approximately the same amount of water as before.

\section{Aquifer Tests at Fairfield Hills Well Field}

Aquifer tests were conducted simultaneously on Wells 3 and 7 to determine the transmissivity and boundary conditions of the aquifer, and to estimate stream inflow from the Pootatuck River. Wells 3 and 7 were selected as the production wells because they are the primary source of water at the Fairfield Hills well field.

Water levels in Well NT-15, a USGS long-term observation well, were monitored before and during the test to see if there were any background trends in the water level (fig. 7). Although there was a downward trend in the water level prior to and during the aquifer test, other influences that occurred during the test (discussed later) were deemed to have a greater effect on the water-level data collected during the test.

The production wells were shut down on July 23, 2007, at 09:49 a.m. for 72 hours to allow for water-level recovery. The pumping part of the test was conducted from July 26, 2007, at 11:00 a.m. to August 3, 2007, at 08:00 a.m. when the pumps were turned off for the aquifer-test recovery period, which continued until August 6, 2007, at 10:00 a.m. At that time, the pumps were returned to normal system operation. 
Table 1. Construction details of production wells, Fairfield Hills well field, Pootatuck River Basin, Newtown, Connecticut.

[LSD, land-surface datum; Registered pumping rate, maximum permissible pumping rate registered with the Connecticut Department of Environmental Protection; Mgal/d, million gallons per day; gal/min, gallons per minute]

\begin{tabular}{|c|c|c|c|c|c|c|c|}
\hline \multirow{2}{*}{ Well } & \multirow{2}{*}{ Date of construction } & \multirow{2}{*}{$\begin{array}{l}\text { Reported depth } \\
\text { below LSD, } \\
\text { in feet }\end{array}$} & \multirow{2}{*}{$\begin{array}{c}\text { Casing } \\
\text { diameter, } \\
\text { in inches }\end{array}$} & \multirow{2}{*}{$\begin{array}{l}\text { Screen } \\
\text { length, } \\
\text { in feet }\end{array}$} & \multicolumn{2}{|c|}{ Registered pumping rate } & \multirow{2}{*}{ Material screened } \\
\hline & & & & & Mgal/d & $\mathrm{gal} / \mathrm{min}$ & \\
\hline 3 & $\begin{array}{c}1932 \\
\text { (refurbished 2006) }\end{array}$ & 64 & $\begin{array}{r}10 \text { outer } \\
8 \text { inner }\end{array}$ & 33 & 0.39 & 270 & Sand and gravel \\
\hline 7 & $\begin{array}{c}1949 \\
\text { (refurbished 2001) }\end{array}$ & 89 & 12 & 20 & 0.67 & 467 & Sand, some gravel \\
\hline 8 & 1949 & 110 & 12 & 20 & 0.77 & 533 & Sand, some gravel \\
\hline
\end{tabular}

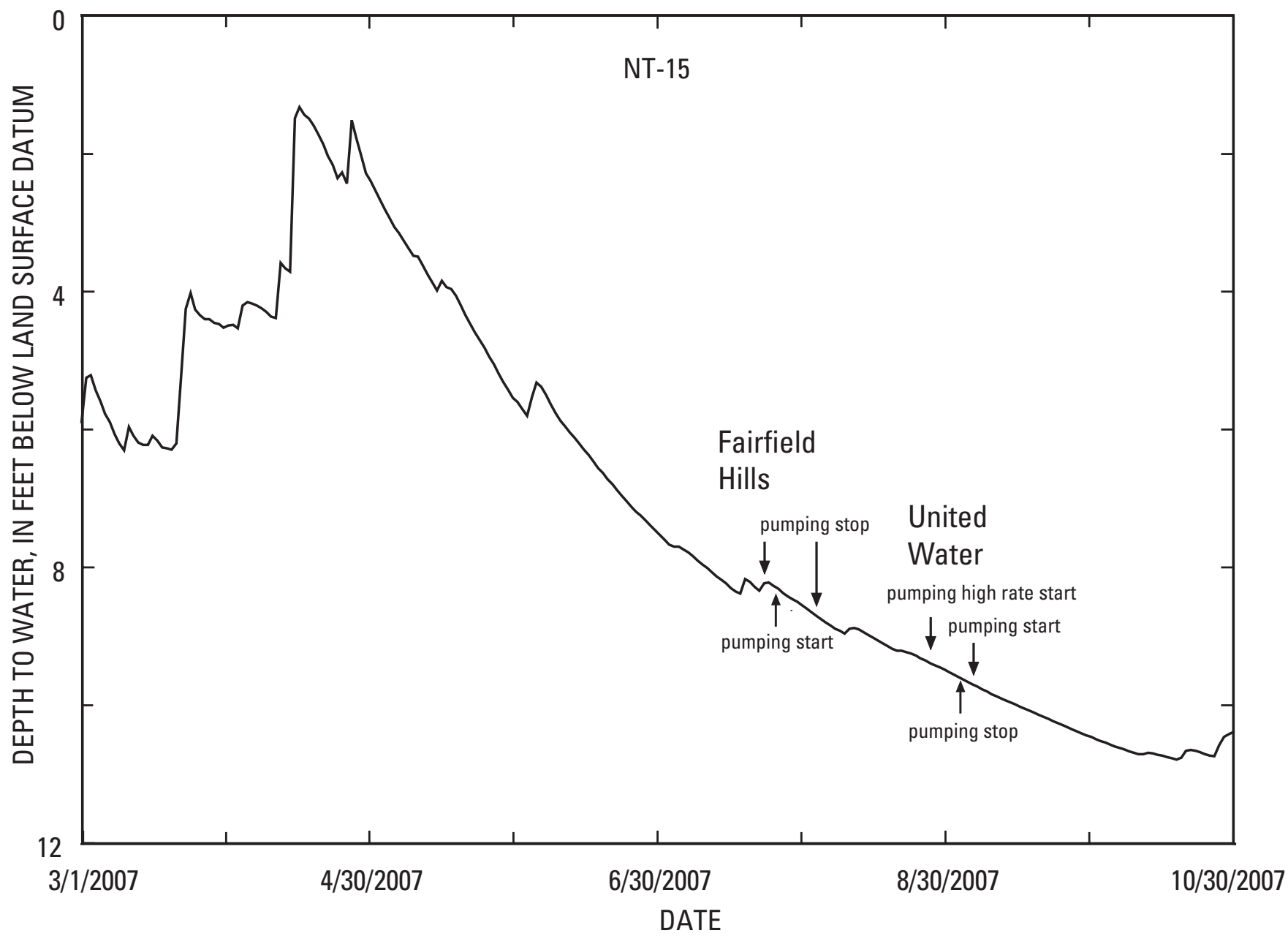

Figure 7. Hydrograph of water levels in Well NT-15, Pootatuck River Basin, Newtown, Connecticut. Location of Well NT-15 shown in figure 1. 
Following CTDEP Level A mapping regulations (State of Connecticut, 1991), the pumping rate was set at the highest feasible constant rate. All water pumped from the well field was discharged to the Pootatuck River downstream from the well-field area and the Berkshire streamgage (012035055). Wells 3 and 7 are not equipped to record continuous pumping rate; both wells record total gallons pumped on mechanical meters, which were read periodically by USGS personnel. Well 3 has a mechanical meter that can be timed to determine the approximate pumping rate in gallons per minute and Well 7 has a digital display of pumping rate. During the pumping part of the aquifer test, the pumping rate of Well 3 averaged $113 \mathrm{gal} / \mathrm{min}$ (based on total volume pumped and total elapsed time) and ranged from 100 to $150 \mathrm{gal} / \mathrm{min}$. The pumping rate of Well 7 averaged $460 \mathrm{gal} / \mathrm{min}$ and ranged from 438 to $465 \mathrm{gal} / \mathrm{min}$ (table 2). Precipitation was monitored in a cup-type rain gage installed at the well field prior to and throughout the test. Amounts were recorded each morning when field personnel arrived onsite although precipitation may have started the previous day.

On July 19, 2007, 7 days prior to the aquifer test, 0.6 in. of rain was measured in the onsite rain gage, on July 21, 2007, 1.5 in. of rain was measured, and on July 24, 2007, the day after the pumps were turned off, 1.3 in. of rain was measured. Because flow in the Pootatuck River continued to be below the maximum streamflow allowed for Level A mapping, the tests were run as scheduled. On July 29, 2007, 3 days after pumping started, 0.41 in. of rain was recorded. The test continued because this amount of precipitation was within the regulations set by CTDEP; however, the rain affected the stage of the Pootatuck River and the water level in observation wells (fig. 8).

\section{Groundwater-Level Monitoring}

Water levels were measured continuously with transducers in the 10 observation wells, in the middle piezometer near Well 7, and in Well 3. Water levels in the remaining five streambed piezometers and Well 7 (fig. 5) were measured manually because access limitations restricted the installation of pressure transducers.

\section{Surface-Water Monitoring}

Stream stage was measured next to each of the piezometers and at the four staff gages (fig. 5). During the aquifer test, streamflow in the Pootatuck River was measured at the upstream and downstream staff gages starting 5 days before the aquifer test and during the test. No measurements were made after pumping stopped. Flow measurements were made at least once each day at each location. Most of the streamflow measurements indicated an increase in flow between the upstream and downstream sites even when Wells 3 and 7 were pumping; however, because of the error of the measurements (discussed earlier), this result is only one of several possibilities. An increase in streamflow may be because of bank or wetland storage of stream water caused by the rain events
Table 2. Pumping rates for Wells 3 and 7 during Fairfield Hills aquifer test, Pootatuck River Basin, Newtown, Connecticut.

[gal/min, gallons per minute]

\begin{tabular}{|c|c|c|c|}
\hline \multicolumn{2}{|c|}{ Well 3} & \multicolumn{2}{|c|}{ Well 7} \\
\hline Date/time & $\begin{array}{l}\text { Pumping } \\
\text { rate, } \\
\text { in gal } / \mathrm{min}\end{array}$ & Date/time & $\begin{array}{c}\text { Pumping } \\
\text { rate, } \\
\text { in gal } / \text { min }\end{array}$ \\
\hline 7/26/2007 11:00 & Pump on & 7/26/2007 11:00 & Pump on \\
\hline $7 / 26 / 200712: 18$ & 130 & $7 / 26 / 2007$ 11:20 & 457 \\
\hline 7/26/2007 12:20 & 125 & 7/26/2007 11:22 & 456 \\
\hline $7 / 26 / 200712: 22$ & 140 & $7 / 26 / 200711: 35$ & 459 \\
\hline 7/26/2007 13:04 & 120 & $7 / 26 / 2007$ 11:45 & 460 \\
\hline $7 / 26 / 2007$ 13:06 & 110 & $7 / 26 / 200711: 55$ & 453 \\
\hline 7/26/2007 13:07 & 125 & 7/26/2007 12:07 & 462 \\
\hline $7 / 26 / 200716: 04$ & 125 & $7 / 26 / 200712: 19$ & 459 \\
\hline 7/27/2007 06:44 & 130 & $7 / 26 / 200712: 39$ & 454 \\
\hline $7 / 27 / 200706: 46$ & 100 & $7 / 26 / 200712: 50$ & 438 \\
\hline 7/27/2007 06:47 & 125 & 7/26/2007 13:04 & 458 \\
\hline 7/27/2007 10:07 & 125 & $7 / 26 / 2007$ 13:13 & 455 \\
\hline $7 / 27 / 2007$ 10:10 & 110 & $7 / 26 / 200713: 32$ & 448 \\
\hline 7/27/2007 14:02 & 125 & $7 / 26 / 2007$ 13:55 & 454 \\
\hline 7/27/2007 14:04 & 120 & $7 / 26 / 200714: 30$ & 460 \\
\hline 7/28/2007 09:04 & 120 & 7/26/2007 17:00 & 459 \\
\hline 7/28/2007 09:08 & 125 & 7/27/2007 08:29 & 462 \\
\hline 7/28/2007 09:20 & 125 & $7 / 27 / 2007$ 14:17 & 461 \\
\hline 7/29/2007 07:01 & 120 & 7/28/2007 07:55 & 456 \\
\hline 7/29/2007 07:05 & 120 & 7/29/2007 07:46 & 463 \\
\hline 7/29/2007 10:07 & 120 & 7/30/2007 11:28 & 465 \\
\hline 7/30/2007 12:54 & 120 & 7/30/2007 13:13 & 460 \\
\hline $7 / 31 / 2007$ 10:45 & 115 & 7/31/2007 07:02 & 458 \\
\hline 8/01/2007 09:47 & 150 & 7/31/2007 09:35 & 459 \\
\hline 8/01/2007 09:51 & 110 & $7 / 31 / 200710: 25$ & 461 \\
\hline 8/01/2007 09:54 & 110 & 8/01/2007 08:19 & 463 \\
\hline 8/02/2007 09:34 & 110 & $8 / 01 / 2007$ 10:39 & 461 \\
\hline 8/03/2007 07:32 & 100 & 8/02/2007 09:00 & 463 \\
\hline 8/03/2007 07:34 & 105 & 8/03/2007 07:00 & 462 \\
\hline 8/03/2007 08:00 & Pump off & 8/03/2007 08:00 & Pump off \\
\hline
\end{tabular}




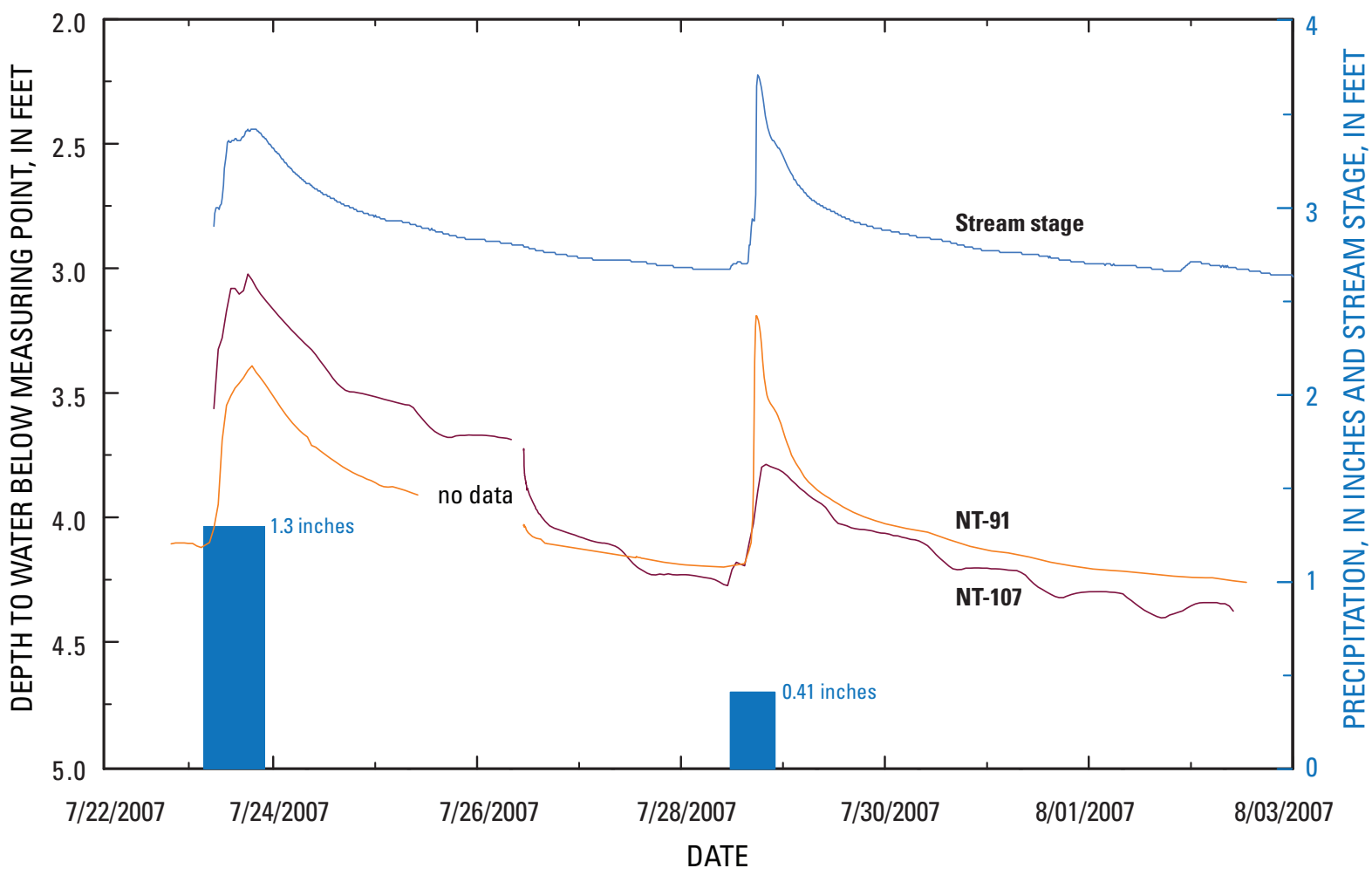

EXPLANATION

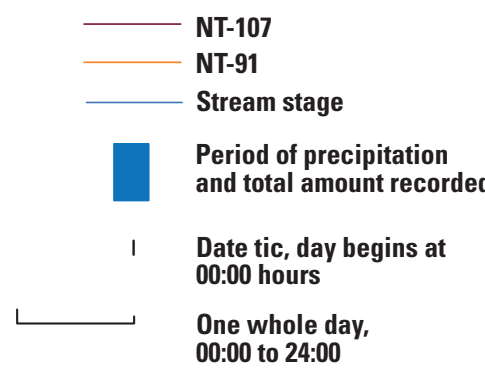

Figure 8. Hydrograph of stream stage recorded at the Berkshire streamgage, water levels in Wells NT-107 and NT-91, and precipitation recorded in the onsite rain gage, Fairfield Hills well field, Pootatuck River Basin, Newtown, Connecticut. Location of Wells NT-107 and NT-91 shown in figure 5.

both before and during the test and groundwater inflow to the stream from the east (opposite side from the well). However, the magnitude of the increase was less when Wells 3 and 7 were pumping (figs. 9 and 10). The flow measurements for the Pootatuck River at the staff gages near Wells 3 and 7 are shown on table 3 and figures 9 and 10.

The relative position of the water levels measured inside (groundwater level) and outside (stream stage) the streambed piezometers (head gradient) determined whether groundwater was discharging to the stream or the stream water was infiltrated into the groundwater (stream inflow). In figure 11, the groundwater level is higher than the stream stage in each streambed piezometer near Well 3 indicating the groundwater is discharging to the stream, but the magnitude of the head gradient is smaller - or zero-during the pumping phase of the test. This is a similar pattern to that observed in the streamflow measurements. The downstream piezometer shows some stream inflow (fig. 11C).

The head gradients in the piezometers near Well 7 indicate that during pumping, water moves from the stream into the aquifer (fig. 12). (Note: no measurement was made immediately after the pump was turned off on August 3, 2007. It is likely that the groundwater and surface-water levels would have been higher. Similarly, the water-level measurements 


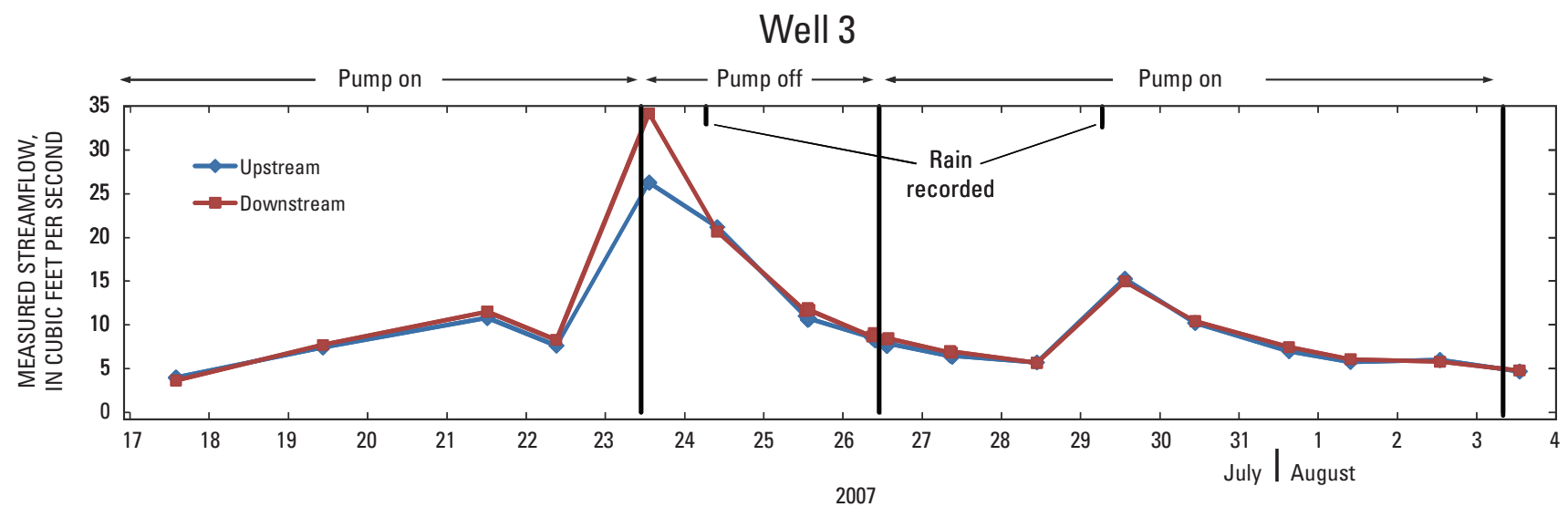

Figure 9. Streamflow measured upstream and downstream from Well 3, Pootatuck River Basin, Newtown, Connecticut. Location of Well 3 shown in figure 5 .

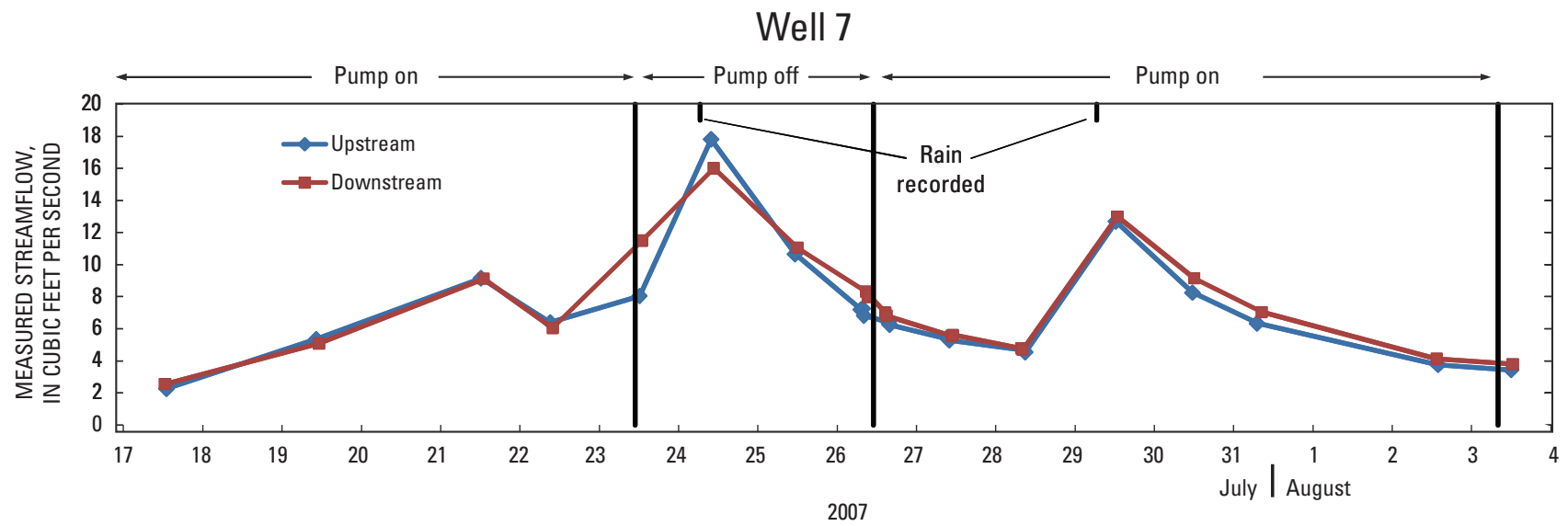

Figure 10. Streamflow measured upstream and downstream from Well 7, Pootatuck River Basin, Newtown, Connecticut. Location of Well 7 shown in figure 5.

may have been higher immediately after the rain event on July 29.) Although the changes in head gradients observed in the piezometers near Well 7 indicate stream inflow and the streamflow measurements do not, the dynamic pattern of the two sets of data is similar (figs. 10 and 12). Because of the probable errors in the streamflow data, mentioned previously, the head-gradient data are considered to be more reliable; thus, it is assumed there is stream inflow near Well 7.

\section{Temperature Monitoring}

Groundwater temperature was measured in all streambed piezometers at varying intervals prior to the aquifer test and in all piezometers except SBP7ms, which was instrumented with a pressure transducer, during the aquifer tests. The data from the piezometers near Well 7 are clearer, and are discussed first. Groundwater temperature measured in the downstream piezometer near Well 7 indicated a good connection between the surface water and the groundwater. The temperature $2 \mathrm{ft}$ below the streambed is very similar to the surface-water temperature ( $0 \mathrm{ft}$ below the streambed) except there is a delay in the fluctuation of the groundwater temperature (fig. 13). The temperatures measured 4 and $6 \mathrm{ft}$ below the streambed showed fluctuations that were progressively more subdued and with increasing delay. There was little temperature change at this location when the well was pumping. In the upstream piezometer (fig. 13), the groundwater temperature became more similar to that of the surface water when the well was pumping, again with a delay that increased with depth. This indicates that surface water was drawn into the aquifer by the production well. 
Table 3. Stage and discharge measurements at local streamflow-measuring sites, Pootatuck River near Fairfield Hills well field, Newtown, Connecticut.

[fts $/ \mathrm{s}$, cubic feet per second; ft, feet; -, indicates a flow loss; --, data not available]

\begin{tabular}{|c|c|c|c|c|c|c|c|c|c|c|c|}
\hline \multicolumn{6}{|c|}{ Production Well 7} & \multicolumn{6}{|c|}{ Production Well 3} \\
\hline & \multicolumn{2}{|c|}{ Upstream } & \multicolumn{3}{|c|}{ Downstream } & \multicolumn{3}{|c|}{ Upstream } & \multicolumn{3}{|c|}{ Downstream } \\
\hline Date & $\begin{array}{c}\text { Discharge, } \\
\text { in } \mathrm{ft}^{3} / \mathrm{s}\end{array}$ & $\begin{array}{c}\text { Stage, } \\
\text { in } \mathrm{ft}\end{array}$ & $\begin{array}{c}\text { Discharge, } \\
\text { in } \mathrm{ft}^{3} / \mathrm{s}\end{array}$ & $\begin{array}{l}\text { Stage, } \\
\text { in } \mathrm{ft}\end{array}$ & $\begin{array}{c}\text { Discharge } \\
\text { difference, } \\
\text { in } \mathrm{ft}^{3} / \mathrm{s}\end{array}$ & Date & $\begin{array}{c}\text { Discharge, } \\
\text { in } \mathrm{ft}^{3} / \mathrm{s}\end{array}$ & $\begin{array}{l}\text { Stage, } \\
\text { in } \mathrm{ft}\end{array}$ & $\begin{array}{c}\text { Discharge, } \\
\text { in } \mathrm{ft}^{3} / \mathrm{s}\end{array}$ & $\begin{array}{l}\text { Stage, } \\
\text { in } \mathrm{ft}\end{array}$ & $\begin{array}{c}\text { Discharge } \\
\text { difference, } \\
\text { in } \mathrm{ft}^{3} / \mathrm{s}\end{array}$ \\
\hline $7 / 03 / 07$ & 3.12 & 14.87 & 2.88 & 21.54 & -0.24 & $7 / 03 / 07$ & 4.77 & 12.64 & 4.65 & 11.42 & -0.12 \\
\hline 7/17/07 & 2.97 & 14.85 & 2.31 & 21.51 & -0.66 & 7/17/07 & 3.60 & 12.59 & 3.74 & 11.38 & 0.14 \\
\hline 7/17/07 & 2.27 & 14.85 & 2.55 & 21.52 & 0.28 & 7/17/07 & 3.96 & 12.59 & 3.64 & 11.38 & -0.32 \\
\hline $7 / 19 / 07$ & 5.35 & 14.96 & 5.09 & 21.62 & -0.26 & $7 / 19 / 07$ & 7.43 & 12.73 & 7.71 & 11.51 & 0.28 \\
\hline $7 / 21 / 07$ & 9.15 & 15.06 & 9.12 & 21.72 & -0.03 & $7 / 21 / 07$ & 10.8 & 12.80 & 11.5 & 11.62 & 0.70 \\
\hline $7 / 22 / 07$ & 6.40 & 15.00 & 6.06 & 21.66 & -0.34 & $7 / 22 / 07$ & 7.63 & 12.74 & 8.28 & 11.51 & 0.65 \\
\hline $7 / 23 / 07$ & 8.04 & 15.06 & 11.5 & 21.80 & 3.46 & $7 / 23 / 07$ & 26.3 & 13.10 & 34.2 & 12.14 & 7.90 \\
\hline $7 / 24 / 07$ & 17.8 & 15.24 & 16.0 & 21.88 & -1.8 & $7 / 24 / 07$ & 21.2 & 13.00 & 20.7 & 11.86 & -0.50 \\
\hline $7 / 25 / 07$ & 10.7 & 15.08 & 11.0 & 21.73 & 0.39 & $7 / 25 / 07$ & 11.0 & 12.82 & 11.6 & 11.64 & 0.60 \\
\hline $7 / 26 / 07$ & 7.20 & 15.02 & 8.32 & 21.67 & 1.12 & $7 / 25 / 07$ & 10.6 & 12.82 & 11.9 & 11.64 & 1.30 \\
\hline $7 / 26 / 07$ & 7.26 & 15.02 & 7.98 & 21.67 & 0.72 & $7 / 25 / 07$ & 10.7 & 12.82 & 11.7 & 11.64 & 1.00 \\
\hline $7 / 26 / 07$ & 6.82 & 15.01 & 8.09 & 21.67 & 1.27 & $7 / 26 / 07$ & 8.54 & 12.76 & 8.67 & 11.56 & 0.13 \\
\hline $7 / 26 / 07$ & 6.41 & 15.00 & 6.99 & 21.66 & 0.58 & $7 / 26 / 07$ & 8.40 & 12.76 & 9.05 & 11.56 & 0.65 \\
\hline $7 / 26 / 07$ & 6.25 & 14.99 & 6.81 & 21.65 & 0.56 & $7 / 26 / 07$ & 8.20 & 12.76 & 8.76 & 11.56 & 0.56 \\
\hline $7 / 27 / 07$ & 5.37 & 14.96 & 5.54 & 21.62 & 0.17 & $7 / 26 / 07$ & 7.57 & 12.74 & 8.33 & 11.54 & 0.76 \\
\hline $7 / 27 / 07$ & 5.28 & 14.96 & 5.62 & 21.62 & 0.34 & $7 / 26 / 07$ & 7.89 & 12.74 & 8.47 & 11.54 & 0.58 \\
\hline $7 / 28 / 07$ & 4.65 & 14.93 & 4.78 & 21.58 & 0.13 & $7 / 27 / 07$ & 6.37 & 12.70 & 6.80 & 11.50 & 0.43 \\
\hline $7 / 28 / 07$ & 4.53 & 14.93 & 4.70 & 21.58 & 0.17 & $7 / 27 / 07$ & 6.50 & 12.69 & 7.00 & 11.50 & 0.5 \\
\hline $7 / 29 / 07$ & 12.7 & 15.13 & 13.0 & 21.78 & 0.31 & $7 / 28 / 07$ & -- & -- & 5.73 & 11.45 & -- \\
\hline $7 / 30 / 07$ & 8.25 & 15.04 & 9.15 & 21.69 & 0.90 & $7 / 28 / 07$ & -- & -- & 5.66 & 11.45 & -- \\
\hline $7 / 31 / 07$ & 6.34 & 15.00 & 7.04 & 21.64 & 0.70 & $7 / 29 / 07$ & 15.3 & 12.88 & 15.0 & 11.72 & -0.31 \\
\hline $8 / 02 / 07$ & 3.75 & 14.91 & 4.12 & 21.57 & 0.37 & $7 / 30 / 07$ & 10.2 & 12.78 & 10.4 & 11.60 & 0.21 \\
\hline \multirow[t]{4}{*}{$8 / 03 / 07$} & 3.43 & 14.90 & 3.79 & 21.56 & 0.36 & $7 / 31 / 07$ & 6.98 & 12.70 & 7.46 & 11.51 & 0.48 \\
\hline & & & & & & $8 / 01 / 07$ & 5.74 & 12.67 & 6.07 & 11.46 & 0.33 \\
\hline & & & & & & $8 / 02 / 07$ & 5.98 & 12.66 & 5.79 & 11.46 & -0.19 \\
\hline & & & & & & $8 / 03 / 07$ & 4.66 & 12.64 & 4.79 & 11.43 & 0.13 \\
\hline
\end{tabular}




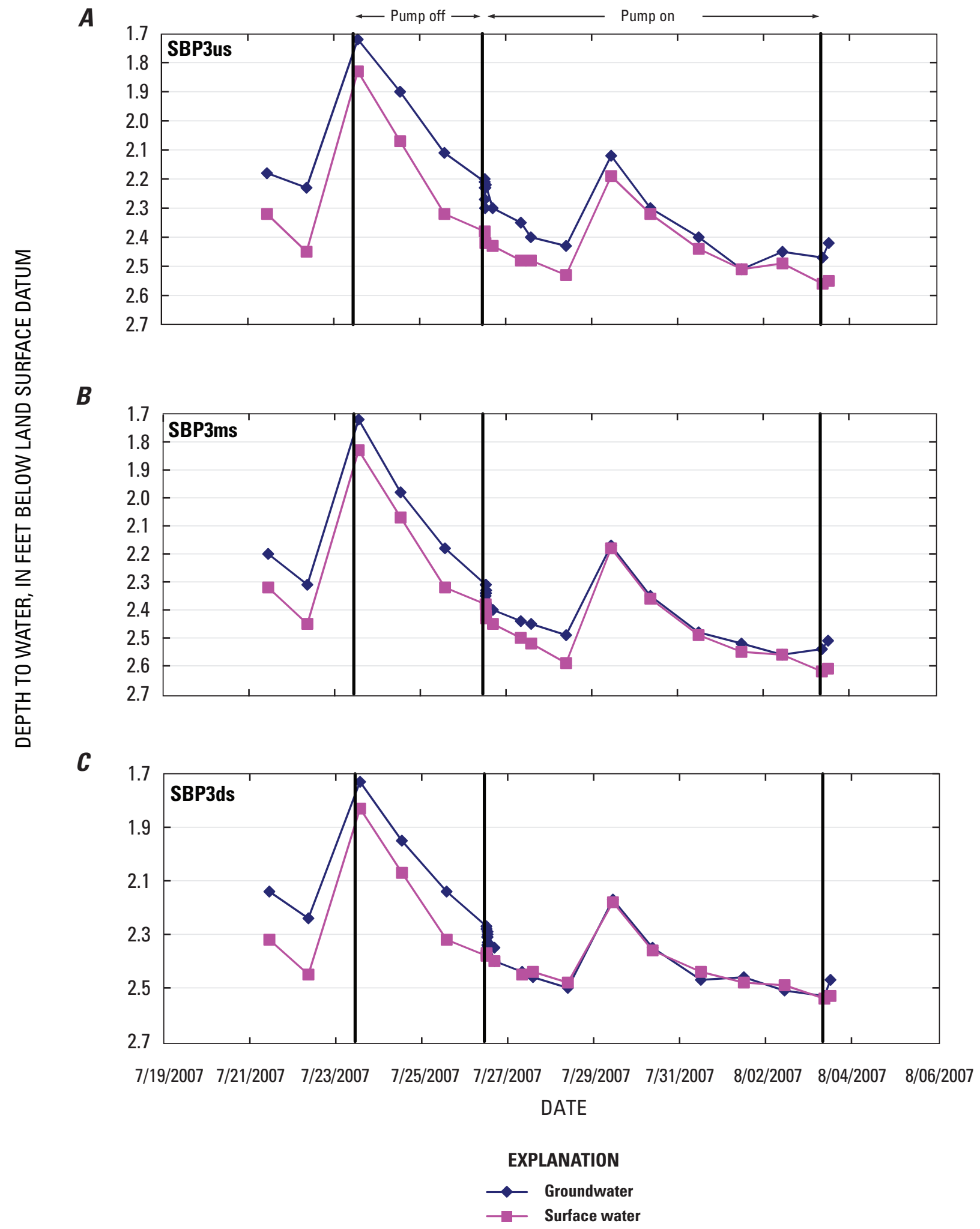

Figure 11. Water-level measurements of surface water and groundwater in $A$, upstream; $B$, middle; and $C$, downstream piezometers near Well 3, Pootatuck River Basin, Newtown, Connecticut. Location of piezometers shown in figure 5. 


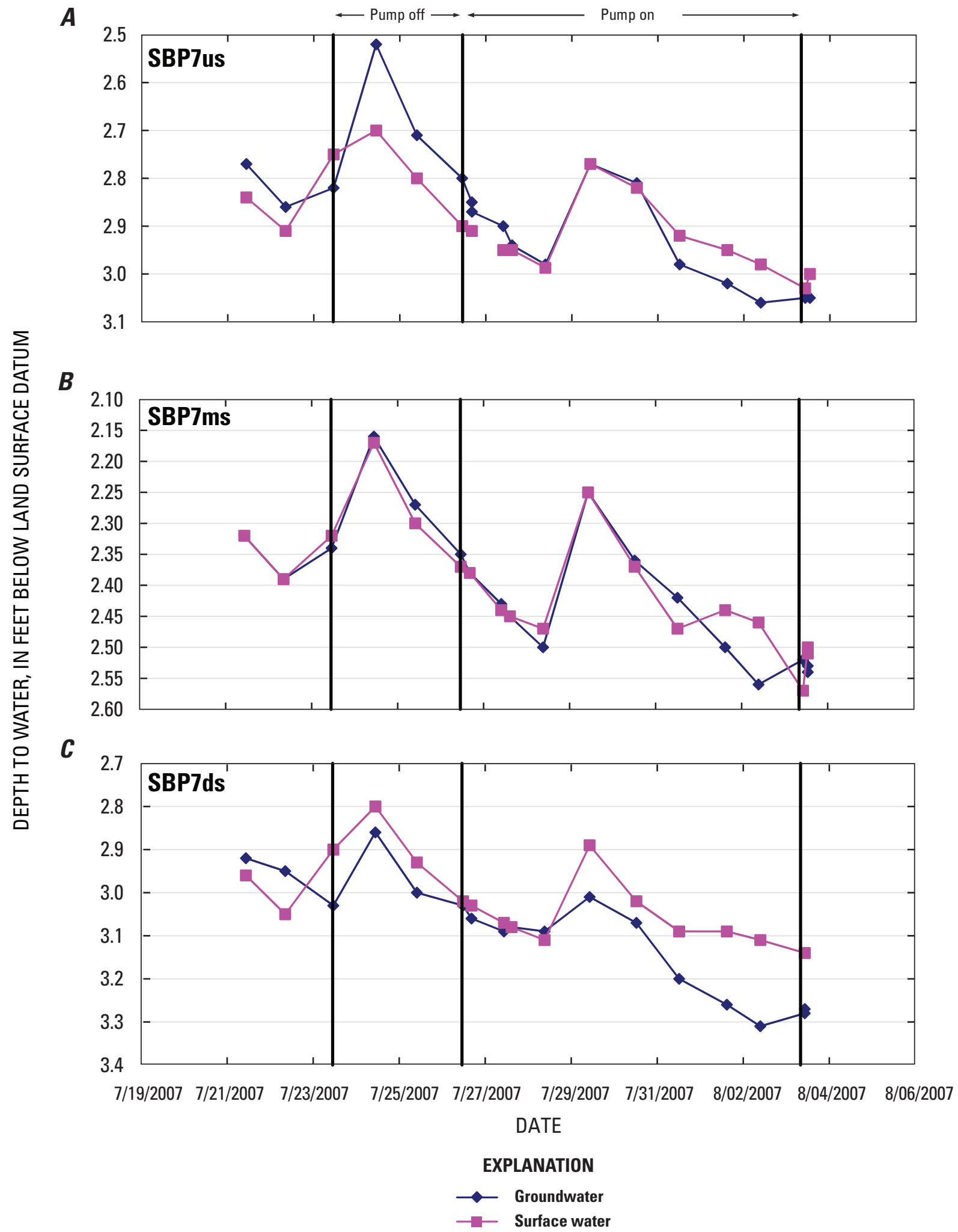

Figure 12. Water-level measurements of surface water and groundwater in $A$, upstream; $B$, middle; and $C$, downstream piezometers near Well 7, Pootatuck River Basin, Newtown, Connecticut. Location of piezometers shown in figure 5. 


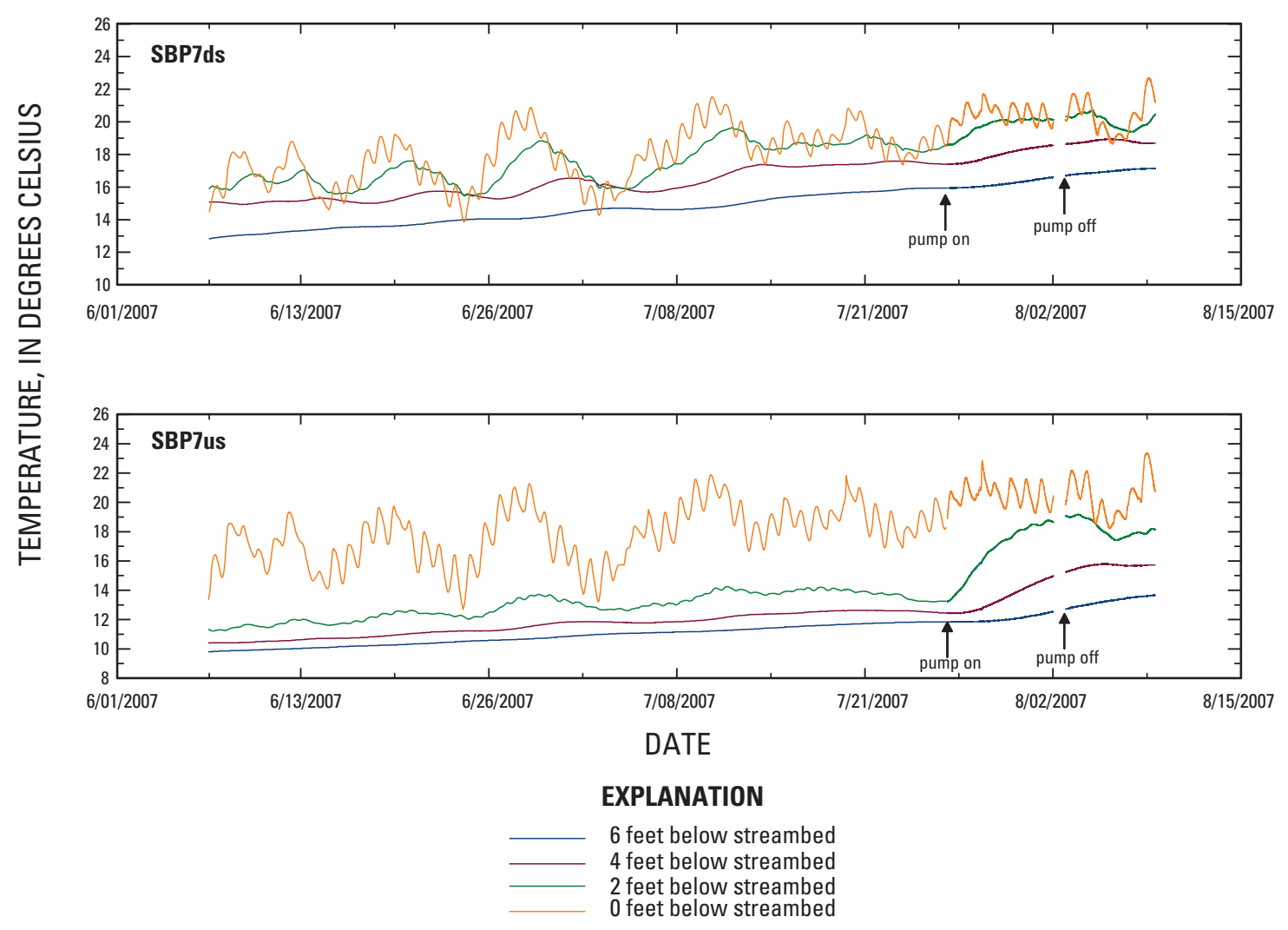

Figure 13. Groundwater temperatures in streambed piezometers SBP7ds (downstream) and SBP7us (upstream) from Well 7, Pootatuck River Basin, Newtown, Connecticut. Location of piezometers shown in figure 5.

In the downstream piezometer near Well 3 , the water temperature at 2 and $6 \mathrm{ft}$ below the streambed became more similar to the temperature of the surface water when the well was pumping, with the delay in the beginning of the change increasing with depth (fig. 14). (There was a problem with data at $4 \mathrm{ft}$ below the streambed; it was not used in the analysis.) This implies movement of surface water into the aquifer. The upstream piezometer showed a similar pattern for the temperature $2 \mathrm{ft}$ below the streambed (fig. 14).

\section{Water-Quality and Isotope Analysis}

Differences between surface-water and groundwater concentrations of chloride and sulfate and the stable-isotope ratios $\delta^{18} \mathrm{O}$ and $\delta^{2} \mathrm{H}$ were used to help estimate their mixing in production Wells 3 and 7 during the aquifer tests. The specific conductance and concentrations of chloride and sulfate generally were higher in samples from Well 3 and from the Pootatuck River than in those from Well 7 (table 4). The sulfate:chloride mass ratio generally was higher with increasing depth (fig. 15A). Concentrations of chloride typically are higher in shallow groundwater because of anthropogenic sources such as road salt and septic leachate; sulfate in deep groundwater can be higher in some Connecticut bedrock aquifers because of weathering of aquifer minerals such as gypsum or pyrite. The sample from Well NT-94, which is upgradient from and close to Well 7, had the highest sulfate:chloride ratio and was assumed to represent ambient groundwater. The ratios of samples from Well 3 are more similar to those in the Pootatuck River, although this well is about $0.5 \mathrm{mi}$ from NT-94, and it is possible that ambient groundwater chemistry may differ between the two locations.

The $\delta^{18} \mathrm{O}$ and $\delta^{2} \mathrm{H}$ values of surface water and groundwater reflect the $\delta^{18} \mathrm{O}$ and $\delta^{2} \mathrm{H}$ values in local precipitation (Craig, 1961; Clark and Fritz, 1997). The $\delta^{2} \mathrm{H}$ and $\delta^{18} \mathrm{O}$ values in river water are enriched by evaporation during summer months because the lighter isotopes of hydrogen and oxygen evaporate more easily than the heavy isotopes of hydrogen and oxygen (Gat, 2008). The slope of the evaporation line is a function of humidity as well as temperature (Clarke and Fritz, 1997). 


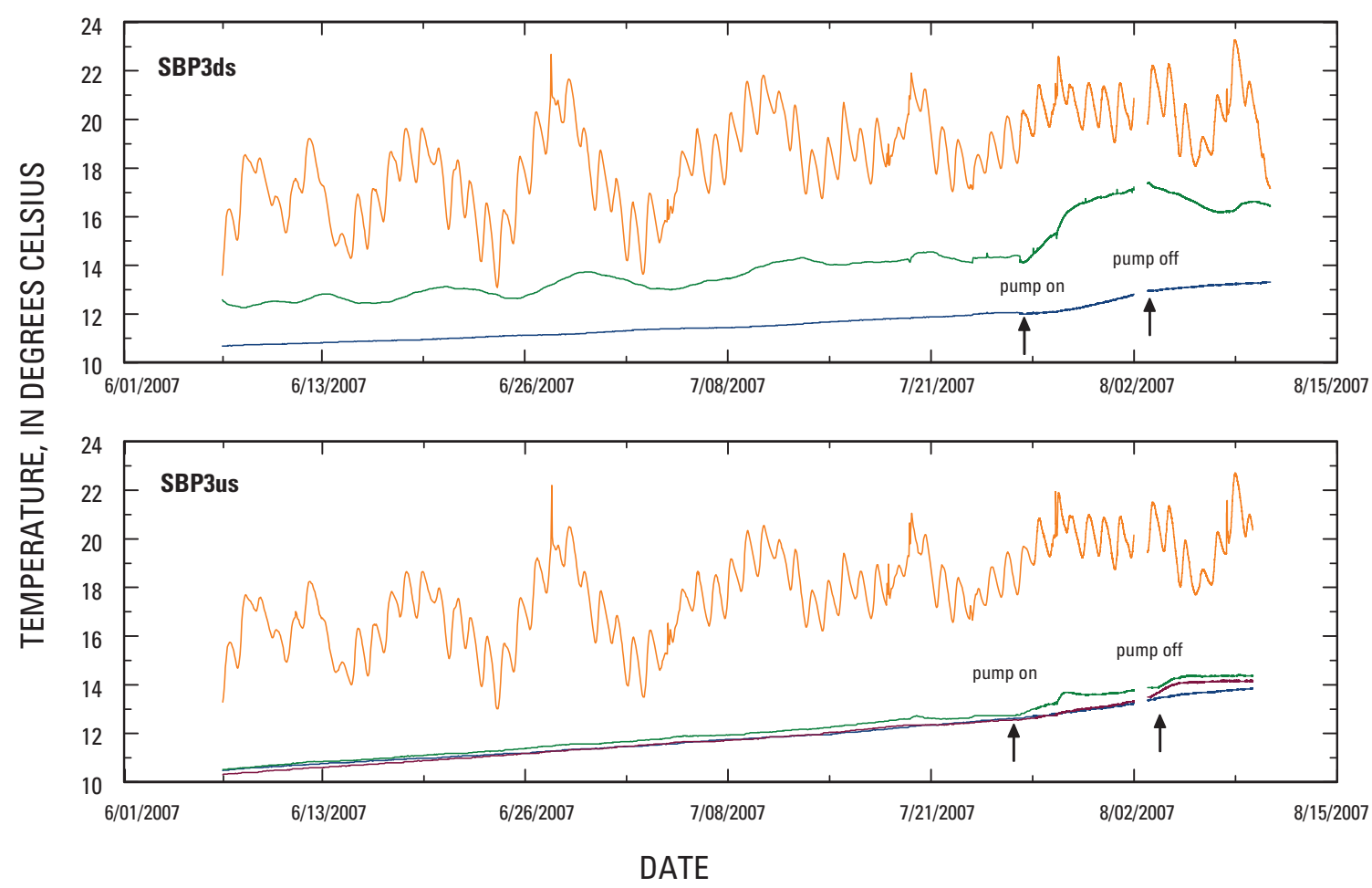

EXPLANATION

6 feet below streambed

4 feet below streambed

2 feet below streambed

0 feet below streambed

Figure 14. Groundwater temperatures in streambed piezometers SBP3ds (downstream) and SBP3us (upstream) from Well 3, Pootatuck River Basin, Newtown, Connecticut. There was a problem with data at 4 feet below streambed. Location of piezometers shown in figure 5 .

During the sampling period, the $\delta^{2} \mathrm{H}$ and $\delta^{18} \mathrm{O}$ values in river water contrasted with $\delta^{2} \mathrm{H}$ and $\delta^{18} \mathrm{O}$ values in groundwater samples, especially in the sample from NT-94, which represents ambient groundwater (table 4 and figs. 15B and 16). The sulfate:chloride mass ratios in water samples increase and $\delta^{2} \mathrm{H}$ values decrease with depth, apparently because of the increased effects of ambient groundwater and decreased effects of surface water on sample chemistry (fig. 15B). The chemistry of samples from the production wells during the aquifer tests is more similar to the chemistry of the Pootatuck River than to ambient groundwater represented by NT-94. The chemistry of samples from Well 3 is very similar to that of the river samples; the sulfate:chloride ratio of Well 3 is only 0.1 higher than the ratio of the river; the sulfate:chloride ratio of Well 7 is about 0.65 higher.

The $\delta^{18} \mathrm{O}$ and $\delta^{2} \mathrm{H}$ values were plotted to help determine stream inflow to groundwater and the resulting effect on groundwater chemistry. The global meteoric water line (MWL), which represents a global average of $\delta^{18} \mathrm{O}$ and $\delta^{2} \mathrm{H}$ in precipitation (and an average of many local or regional meteoric water lines that differ from the global line because of varying climatic and geographic parameters), has a slope of about 8 (Craig, 1961; Clark and Fritz, 1997). Precipitation that runs off to streams or that quickly recharges groundwater reflects the $\delta^{18} \mathrm{O}$ and $\delta^{2} \mathrm{H}$ of the local precipitation. Transpiration does not involve fractionation (Zimmerman and others, 1967; Förstel, 1982), although some vegetation such as permanent grasses can increase evaporative loss seasonally (Darling and Bath, 1988). The sample from NT-94, which is upgradient from Well 7, is relatively depleted in the heavy isotopes oxygen-18 and hydrogen-2 (deuterium) and reflects a greater contribution from ambient groundwater (fig. 16). The $\delta^{18} \mathrm{O}$ and $\delta^{2} \mathrm{H}$ values for NT- 85 and NT- 86 are relatively enriched and appear to show more influence from the river (fig. 16). A line drawn through these data points has a slope of 9.08 and is very similar to a local MWL (LMWL) that is based on groundwater and surface-water samples in part of the Pomperaug River Basin, which is about 9 mi to the north-northeast (Brown and others, 2009). 
Table 4. General chemical characteristics and concentrations of chloride and sulfate, sulfate:chloride mass ratios, and stable isotope values for $\delta^{2} \mathrm{H}$ and $\delta^{18} \mathrm{O}$ in the Pootatuck River Basin, Newtown, Connecticut.

[ft, feet; LSD, land-surface datum; ${ }^{\circ} \mathrm{C}$, degrees Celsius; $\mu \mathrm{S} / \mathrm{cm}$, microsiemens per centimeter at 25 degrees Celsius; $\mathrm{mg} / \mathrm{L}$, milligrams per liter; $\mathrm{SO}$, sulfate; $\mathrm{Cl}$, chloride; $\delta^{2} \mathrm{H}$, stable isotope ratio of hydrogen-2 to hydrogen-1; $\delta^{18} \mathrm{O}$, stable isotope ratio of oxygen-18 to oxygen-16; na, not applicable; --, no data]

\begin{tabular}{|c|c|c|c|c|c|c|c|c|c|c|c|}
\hline Site & $\begin{array}{c}\text { Sample } \\
\text { depth, } \\
\text { in ft } \\
\text { below LSD }\end{array}$ & Date & Time & $\begin{array}{l}\text { Temper- } \\
\text { ature, } \\
\text { in }{ }^{\circ} \mathrm{C}\end{array}$ & $\begin{array}{l}\text { Specific con- } \\
\text { ductance, } \\
\text { in } \mu \mathrm{S} / \mathrm{cm}\end{array}$ & $\mathrm{pH}$ & $\begin{array}{c}\text { Chloride, } \\
\text { in } \mathrm{mg} / \mathrm{L}\end{array}$ & $\begin{array}{l}\text { Sulfate, } \\
\text { in } \mathrm{mg} / \mathrm{L}\end{array}$ & $\begin{array}{c}\mathrm{SO}_{4}: \mathrm{CI} \\
\text { ratio }\end{array}$ & $\begin{array}{c}\delta^{2} H \\
\text { in per mil }\end{array}$ & $\begin{array}{c}\delta^{18} 0 \\
\text { in per mil }\end{array}$ \\
\hline Well 7 & 89 & $7 / 26 / 2007$ & $12: 12$ & 11.5 & 106 & 7.04 & 7.7 & 8.6 & 1.12 & -45.3 & -7.6 \\
\hline $\begin{array}{l}\text { Pootatuck } \\
\text { River }\end{array}$ & na & $7 / 26 / 2007$ & $12: 35$ & 17.1 & 191 & 7.61 & 22 & 9.5 & 0.43 & -43.5 & -6.8 \\
\hline Well 7 & 89 & $7 / 26 / 2007$ & $13: 30$ & 11.4 & 110 & 7.01 & -- & -- & -- & -- & -- \\
\hline Well 3 & 58.5 & $7 / 26 / 2007$ & $14: 20$ & 12.0 & 282 & 7.00 & 20 & 10 & 0.50 & -42.9 & -7.2 \\
\hline Well 3 & 58.5 & $7 / 28 / 2007$ & $14: 00$ & -- & 264 & 6.81 & -- & -- & -- & -- & -- \\
\hline Well 7 & 89 & $7 / 29 / 2007$ & $15: 00$ & -- & 113 & 6.54 & 8.6 & 9.3 & 1.08 & -45.1 & -7.5 \\
\hline Well 7 & 89 & $8 / 02 / 2007$ & $14: 39$ & 10.7 & 91.1 & 7.23 & 9.0 & 9.4 & 1.04 & -45.7 & -7.5 \\
\hline NT-85 & 79.7 & $8 / 02 / 2007$ & $16: 12$ & 10.9 & 110 & 8.26 & 7.7 & 11 & 1.43 & -45.4 & -7.6 \\
\hline NT-86 & 21.2 & $8 / 02 / 2007$ & $15: 35$ & 12.5 & 128 & 7.51 & 10 & 9.2 & 0.92 & -45.0 & -7.5 \\
\hline $\begin{array}{l}\text { Pootatuck } \\
\text { River }\end{array}$ & na & $8 / 02 / 2007$ & $13: 40$ & 21.6 & 203 & 7.43 & 26 & 10 & 0.39 & -43.0 & -6.9 \\
\hline Well 3 & 58.5 & $8 / 02 / 2007$ & $15: 00$ & -- & 283 & 7.08 & 26 & 13 & 0.49 & -44.5 & -7.2 \\
\hline NT-94 & 47.5 & $8 / 06 / 2007$ & $14: 38$ & 9.9 & 45.0 & 6.67 & 1.7 & 8.3 & 4.88 & -46.6 & -7.7 \\
\hline
\end{tabular}

Water that has evaporated from surface water or that has mixed with evaporated water plots below the MWL, typically along a divergent line with a lesser slope of 5 or 6 for most natural waters (Craig, 1957). The mean $\delta^{2} \mathrm{H}$ and $\delta^{18} \mathrm{O}$ values from the Pootatuck River and samples from both production wells at the end of the aquifer test likely plot along an evaporation water line (EWL). In this study, there were no data for samples that have undergone different stages of evaporation to complete the EWL typically observed; therefore, EWLs inferred from water samples collected in two other studies, in Connecticut and adjacent New York, were used as surrogate EWLs for this analysis (fig. 16). An EWL with a slope of 6.08 was based mainly on groundwater samples affected by nearby streams in the Pomperaug River Basin (Brown and others, 2009); and an EWL with a slope of 5.75 was based on lake samples collected in Wawarsing, New York (C.J. Brown, U.S. Geological Survey, written commun., 2009). In addition, laboratory studies show that the heavy isotope enrichment ratio $\delta^{2} \mathrm{H} / \delta^{18} \mathrm{O}$ at ordinary temperatures consistently follows a slope of about 5 (Craig, 1961). Therefore, EWLs with slopes of 6.08, 5.75, and 5 were drawn on figure 16 to estimate mixing of surface water with groundwater. All three lines could have been drawn through each of the points representing sampled Pootatuck River water; however, for simplicity, only the "envelope" area created by these lines is shown (fig. 16).

$\delta^{2} \mathrm{H}$ and $\delta^{18} \mathrm{O}$ values in samples from wells near the river, including Wells 3 and 7, likely reflect stream inflow from the river. Because the mixing lines show little or no change in $\delta^{18} \mathrm{O}$, only $\delta^{2} \mathrm{H}$ was used in mixing calculations. The fraction of surface water in the mixture is calculated using the following expression:

$$
\mathrm{f}_{\mathrm{rw}}=\left(\mathrm{Y}_{\mathrm{m}}-\mathrm{Y}_{\mathrm{gw}}\right) /\left(\mathrm{Y}_{\mathrm{sw}}-\mathrm{Y}_{\mathrm{gw}}\right)
$$

where

$$
\begin{array}{ll}
\mathrm{Y}_{\mathrm{m}}, \mathrm{Y}_{\mathrm{gw}}, \text { and } \mathrm{Y}_{\mathrm{sw}} & \begin{array}{l}
\text { is the fraction of river water, and } \\
\text { denote the } \delta^{2} \mathrm{H} \text { in the mixture, } \\
\text { groundwater, and surface water, } \\
\text { respectively. }
\end{array}
\end{array}
$$

A comparison of samples collected from the production wells at the end of the aquifer test with the three surrogate evaporation lines indicates that some of the pumped water originates from the river (table 5). 

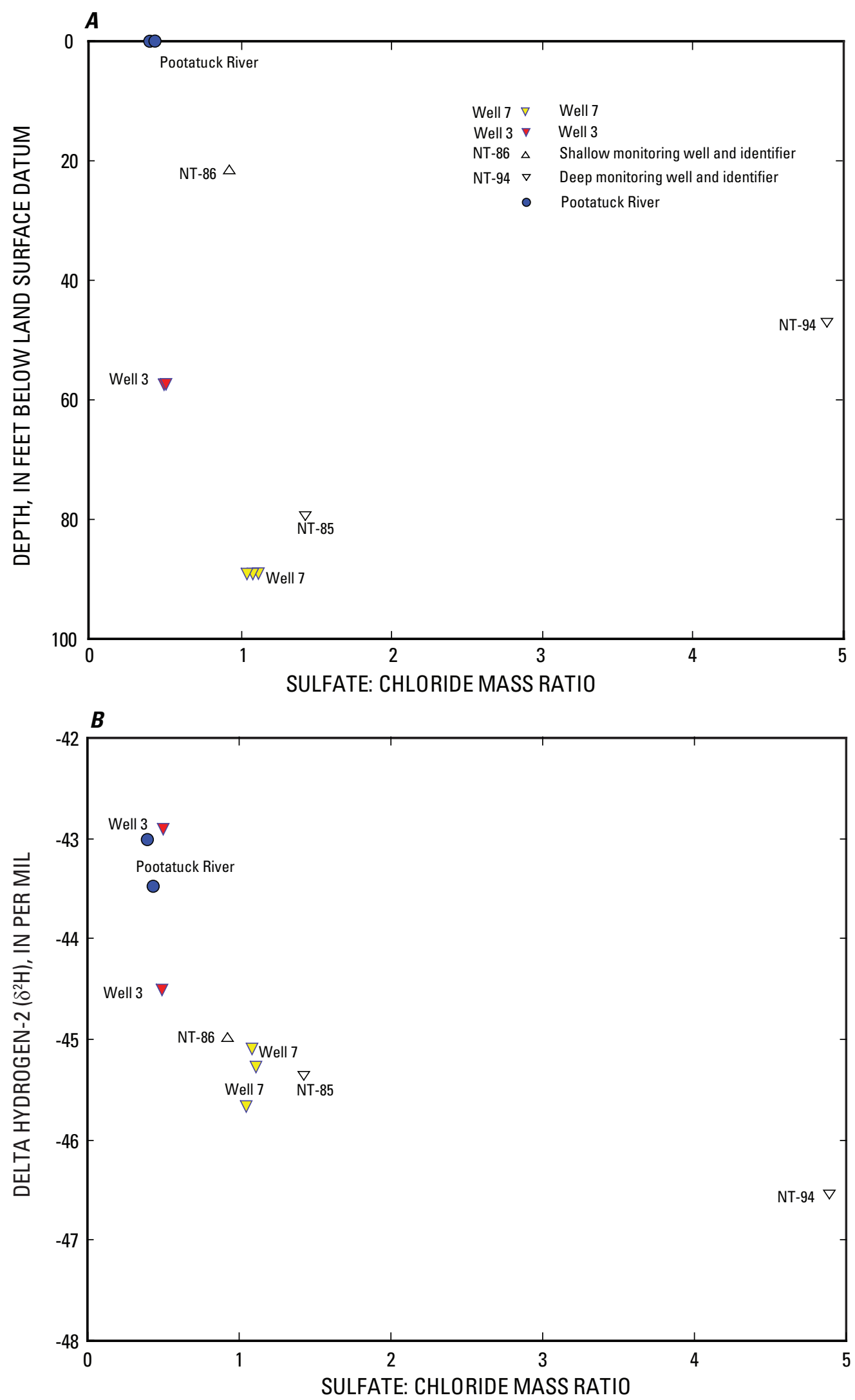

Figure 15. Relation between sulfate: chloride mass ratios and $A$, depth below ground surface and $B$, isotope values of delta hydrogen-2 $\left(\delta^{2} \mathrm{H}\right)$ in groundwater and surface water in the Pootatuck River Basin, Newtown, Connecticut. Data collected between July 26 and August 6, 2007. Location of wells sampled shown in figure 5. 


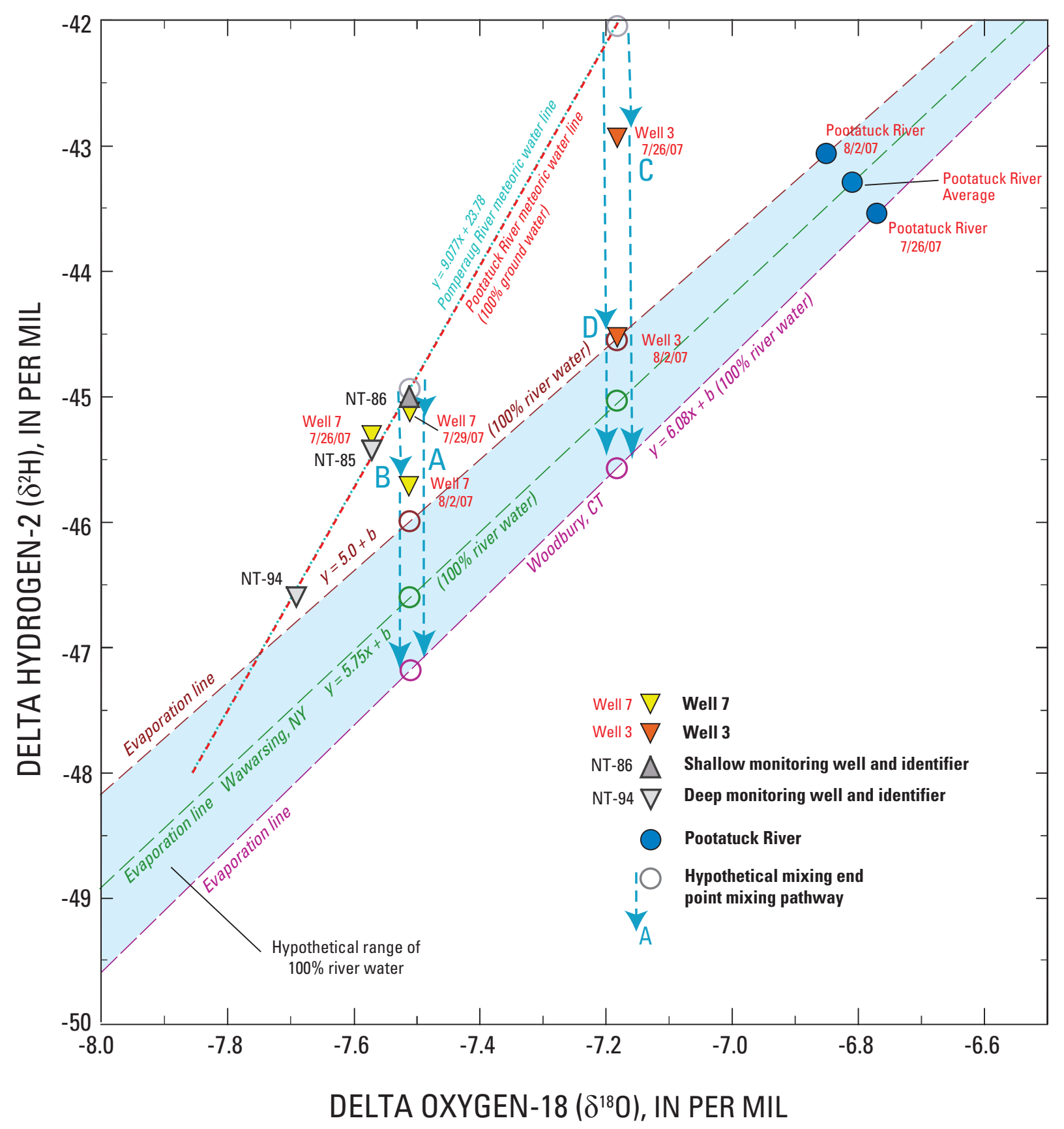

Figure 16. Isotope values of delta oxygen-18 as a function of delta hydrogen-2 for samples of groundwater and surface water in the Pootatuck River Basin, Newtown, Connecticut. Data collected between July 26 and August 2, 2007. Location of wells sampled shown in figure 5 . 


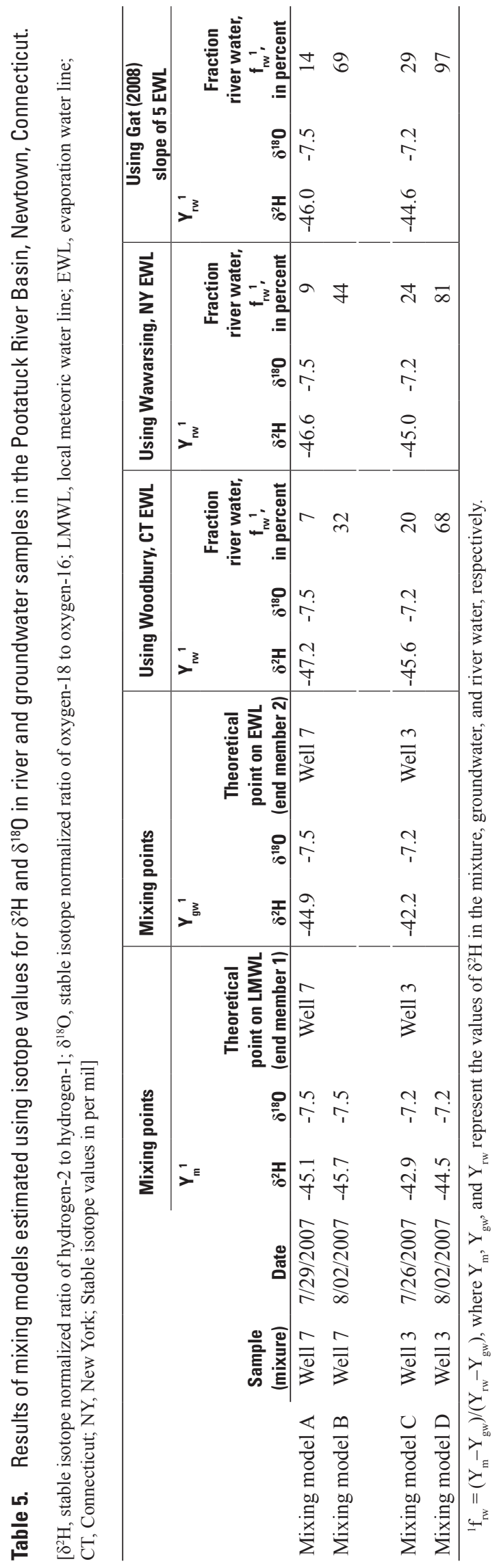


Three samples were collected at Well 7. A shift in $\delta^{2} \mathrm{H}$ was accompanied by a shift in $\delta^{18} \mathrm{O}$ from the start of pumping to a second sample collected on July 29, 2007, after 3 days of pumping (fig. 16). This shift may result from analytical uncertainty, which is 2 per mil for $\delta^{2} \mathrm{H}$ and 0.2 per mil for $\delta^{18} \mathrm{O}$ at the 2-sigma level. A water-mixing calculation using $\delta^{2} \mathrm{H}$ in the second Well 7 sample shows a range in contribution of 7 to 14 percent river water, using the three surrogate evaporation lines defined above to determine the end member (Mixing model A, table 5). A similar calculation for the third sample from Well 7, collected on August 2, 2007, near the end of pumping, showed a range in contribution of 32 to 69 percent river water (Mixing model $\mathrm{B}$, table 5).

Two samples were collected at Well 3. At the beginning of the test between 20 and 29 percent of the sample was estimated to have been derived from the river (table 5). The second sample from Well 3 collected near the end of pumping on August 2, 2007, showed a range in contribution of 68 to 97 percent river water. Note that these estimates are semiquantitative because of the analytical error of $\delta^{2} \mathrm{H}$ and $\delta^{18} \mathrm{O}$, the LMWL was interpolated, and the evaporation lines were estimated.

The water-quality and stable-isotope analysis corroborates the stream inflow shown by the streamflow and piezometer data near Well 7; however, the water-quality and stable-isotope analysis contradicts the streamflow and piezometer data near Well 3. It was not possible to determine the reason for this discrepancy within the scope of this project; more stable-isotope samples would be necessary to reach a definitive conclusion of stream inflow at Well 3.

\section{Analysis of Aquifer Tests at Fairfield Hills Well Field}

Prepumping data from observation wells were plotted to establish if corrections to the drawdown data were necessary to account for the effects of natural water-level trends. Water levels from the observation wells near Well 7 fluctuated with the pumping, so it could not be determined whether there was a trend. Well 3 was undergoing adjustments related to recent refurbishing and was not in use prior to the aquifer test. Although water levels in observation wells near Well 3 showed a slight downward trend in the weeks before the aquifer test (fig. 17), the effect of the rain events recorded on July 19, 21, 24, and 29 had a greater effect on the data, so no correction was made for the antecedent water-level trend. The small, regular groundwater-level fluctuations prior to the test are attributed to nearby pumping at a manufacturing facility (Frederick Hurley, Newtown, oral commun., 2007) and were not considered in the analysis because they were relatively consistent. Well 3 was not able to maintain a constant pumping rate; therefore the results of the test are estimates.
The large water level fluctuation on July 19, 2007, was because of a precipitation event. The large fluctuation on July 23,2007 , was because of both the shut down of the production wells and a precipitation event that began on that date. (The precipitation was recorded on the following day, July 24, 2007.)

The distance-drawdown method for calculating transmissivity assumes the aquifer is confined and the observation wells fully penetrate the aquifer. Because the aquifer at Wells 3 and 7 is unconfined, drawdown data collected during the aquifer tests were corrected for partial penetration using the following equation (Cooper and Jacob, 1946; Kruseman and DeRidder, 1990):

$$
\mathrm{s}^{\prime}=\mathrm{s}-\left(\mathrm{s}^{2} / 2 \mathrm{~b}\right)
$$

where

$$
\begin{aligned}
& \mathrm{s}^{\prime} \quad \text { is the corrected drawdown displacement, } \\
& \mathrm{S} \text { is the observed drawdown, and } \\
& \mathrm{b} \text { is the saturated thickness of the aquifer. }
\end{aligned}
$$

The observed and corrected maximum drawdowns are shown in table 6. Table 7 shows transmissivity and hydraulic conductivity values calculated for the aquifer in the vicinity of Wells 3 and 7.

Table 6. Observed and corrected drawdowns in observation wells, Fairfield Hills well field, Pootatuck River Basin, Newtown, Connecticut.

[ft, feet]

\begin{tabular}{ccc}
\hline Well identifier & $\begin{array}{c}\text { Observed drawdown, } \\
\text { in ft }\end{array}$ & $\begin{array}{c}\text { Corrected drawdown', } \\
\text { in ft }\end{array}$ \\
\hline NT-85 & 3.03 & 2.97 \\
NT-86 & 1.86 & 1.77 \\
NT-90 & 3.29 & 3.23 \\
NT-91 & 0.23 & 0.23 \\
NT-94 & 7.74 & 7.02 \\
NT-106 & 1.05 & 1.03 \\
NT-107 & 0.65 & 0.64 \\
NT-108 & 1.41 & 1.39 \\
NT-109 & 1.91 & 1.86 \\
NT-110 & 0.32 & 0.32 \\
\hline
\end{tabular}

${ }^{1}$ Drawdowns corrected for partial penetration using method described by Cooper and Jacob (1946) and Kruseman and DeRidder (1990). 

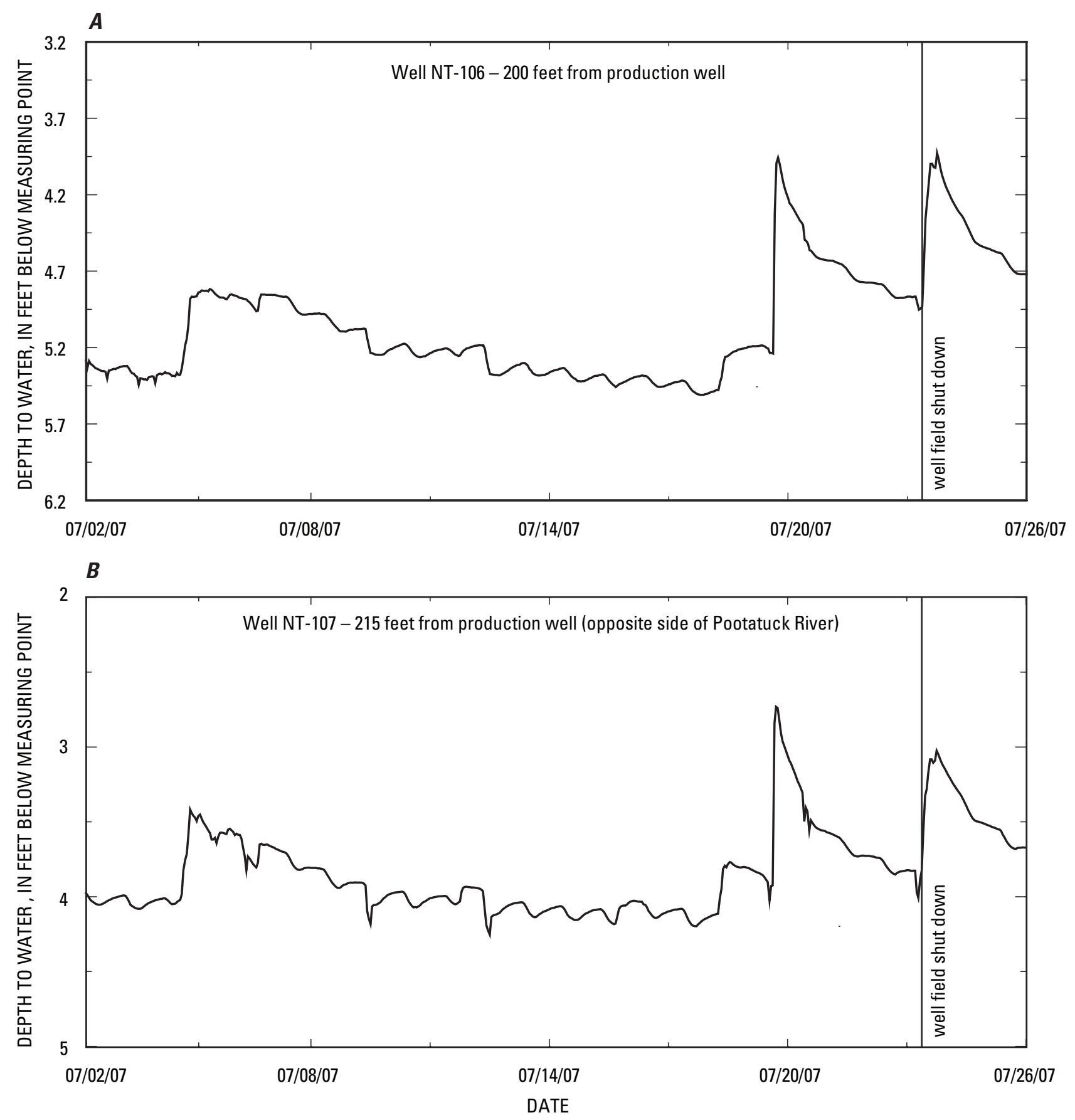

Figure 17. Pretest water levels in observation wells $A$, NT-106 and $B$, NT-107 near Well 3, Fairfield Hills well field, Pootatuck River Basin, Newtown, Connecticut. Location of observation wells NT-106 and NT-107 shown in figure 5. 
Table 7. Transmissivity and hydraulic conductivity calculated from aquifer tests, Pootatuck River Basin, Newtown, Connecticut.

$\left[\mathrm{ft}^{2} / \mathrm{d}\right.$, feet squared per day; $\mathrm{ft} / \mathrm{d}$, feet per day]

\begin{tabular}{cccc}
\hline $\begin{array}{c}\text { Production } \\
\text { well }\end{array}$ & $\begin{array}{c}\text { Saturated } \\
\text { thickness, } \\
\text { in feet }\end{array}$ & $\begin{array}{c}\text { Transmissivity } \\
\text { in } \mathrm{ft}^{2} / \mathrm{d}\end{array}$ & $\begin{array}{c}\text { Hydraulic con- } \\
\text { ductivity, } \\
\text { in } \mathrm{ft} / \mathrm{d}\end{array}$ \\
\hline
\end{tabular}

\begin{tabular}{clrl}
\hline \multicolumn{4}{c}{ Fairfield Hills well field } \\
\hline Well 3 & 55 & 3,200 & 58 \\
Well 7 & 85 & 4,700 & 55 \\
\hline \multicolumn{4}{c}{ United Water well field ${ }^{2}$} \\
\hline Well 2 & 80 & 20,000 & 250 \\
\hline
\end{tabular}

${ }^{1}$ Transmissivity calculated from distance-drawdown method (Cooper and Jacob, 1946).

${ }^{2}$ Data from aquifer test run in June 1981 (Kevin Moran, United Water Company, written commun., 2006).

\section{United Water Well Field}

\section{Site Description}

The United Water well field consists of two wells $245 \mathrm{ft}$ apart in stratified glacial deposits, which are 50 to $85 \mathrm{ft}$ thick. The identification numbers of these wells is confusing because the United Water numbers-Newtown Wells 1 and 2-are the reverse of those in CTDEP records. The United Water numbers will be used in this report (fig. 6). Information on the wells is provided in table 8 .

\section{Pumping Information}

Well 2 is the primary production well with a registered diversion of $1.08 \mathrm{Mgal} / \mathrm{d}$ (750 gal $/ \mathrm{min})$. Well 1 is the reserve well, with a registered diversion of $0.50 \mathrm{Mgal} / \mathrm{d}$ (350 gal $/ \mathrm{min})$, and operates with Well 2 during periods of high water demand. The system operates as an on-demand system. Wells 1 and 2 share a digital meter, which measures total thousands of gallons pumped; this meter is read daily to produce monthly production reports. In addition, the operating hours for each well are tallied. Pumping rates are calculated from average gallons per minute, total gallons pumped, and the production times. The reported range of total monthly volume of groundwater withdrawal for Well 1 for the years 1997 to 2001 was 0 to $1.8 \mathrm{Mgal}$ and for Well 2 was 9.0 to 19.6 Mgal.

\section{Induced Infiltration Test at United Water Well Field}

A short-duration, single production-well recovery test was conducted on Well 2, the primary source of water at the United Water well field, because lack of available storage and the need to provide fire protection and uninterrupted potable water to customers of United Water precluded shutting down the production wells for 3 days to allow groundwater-level recovery. The maximum time the system could be shut down was approximately 9.5 hours during late-night hours when there was minimal demand for water. Thus, it was not possible to run a typical aquifer test on the United Water well field. Because of the system limitations, the CTDEP approved a plan to collect data to verify stream inflow from the Pootatuck River by conducting a short-duration, reverse aquifer test. The aquifer properties were calculated from data collected during historical aquifer tests.

Instead of the required minimum 3-day shutdown of the well field followed by a 5 -day pumping period, the pumping rate of Well 2 was increased on August 27, 2007, to the maximum rate that the system could sustain; prior to August 27, 2007, both Wells 1 and 2 were pumping. The target pumping rate of $750 \mathrm{gal} / \mathrm{min}$, the registered rate, could not be achieved, so the rate was set at approximately $650 \mathrm{gal} / \mathrm{min}$. A hydrograph of pumping rate prior to, during, and after the aquifer test is shown in figure 18. During this period of increased pumping, more water was pumped than was needed to supply the customers of United Water. The excess was discharged from a hydrant to a tributary that joins the Pootatuck River downstream from the well field. This discharge may have caused a backwater condition, which will be discussed later.

After 8 days of pumping at the higher rate, Well 2 was shut down on September 4, 2007, at 10:06 p.m. Monitoring of water-level recovery and stream stage continued until September 5, 2007, at 07:38 a.m. when available system storage was depleted and Well 2 was reactivated.

Table 8. Construction details of production wells, United Water well field, Pootatuck River Basin, Newtown, Connecticut.

[LSD, land-surface datum; Registered pumping rate, maximum permissible pumping rate registered with the Connecticut Department of Environmental Protection; Mgal/d, million gallons per day; gal/min, gallons per minute]

\begin{tabular}{|c|c|c|c|c|c|c|c|}
\hline \multirow{2}{*}{ Well } & \multirow{2}{*}{$\begin{array}{l}\text { Date of con- } \\
\text { struction }\end{array}$} & \multirow{2}{*}{$\begin{array}{l}\text { Reported depth } \\
\text { below LSD, } \\
\text { in feet }\end{array}$} & \multirow{2}{*}{$\begin{array}{l}\text { Casing diameter, } \\
\text { in inches }\end{array}$} & \multirow{2}{*}{$\begin{array}{l}\text { Screen length, } \\
\text { in feet }\end{array}$} & \multicolumn{2}{|c|}{ Registered pumping rate } & \multirow{2}{*}{ Material screened } \\
\hline & & & & & Mgal/d & $\mathrm{gal} / \mathrm{min}$ & \\
\hline 1 & $1980 \mathrm{~s}$ & 50 & 16 & 10 & 0.50 & 350 & Coarse sand and gravel \\
\hline 2 & $1980 \mathrm{~s}$ & 83 & 16 & 20 & 1.08 & 750 & Coarse sand and gravel \\
\hline
\end{tabular}




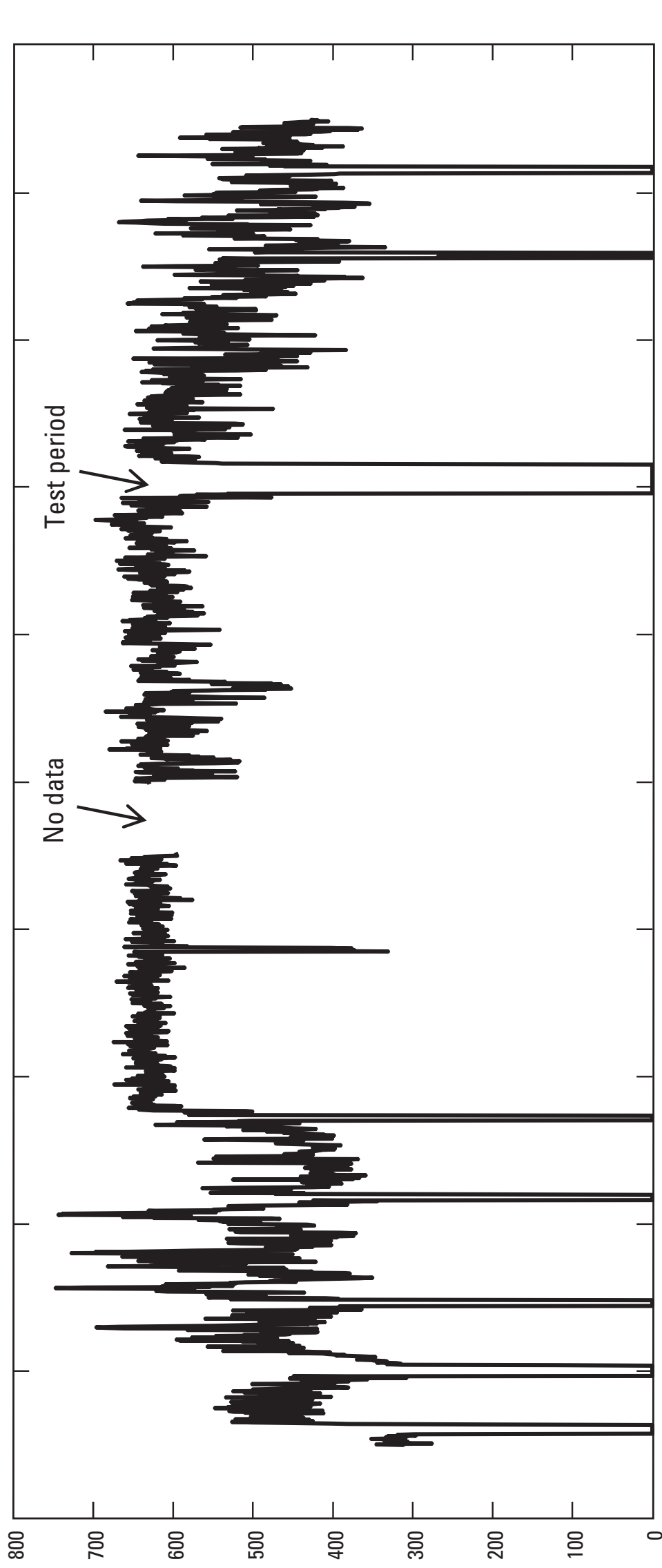

옹

홍

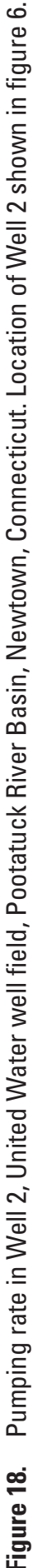

亭 岩

옹

옹
웡
옹
웡

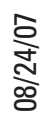

옹

홍

홍 


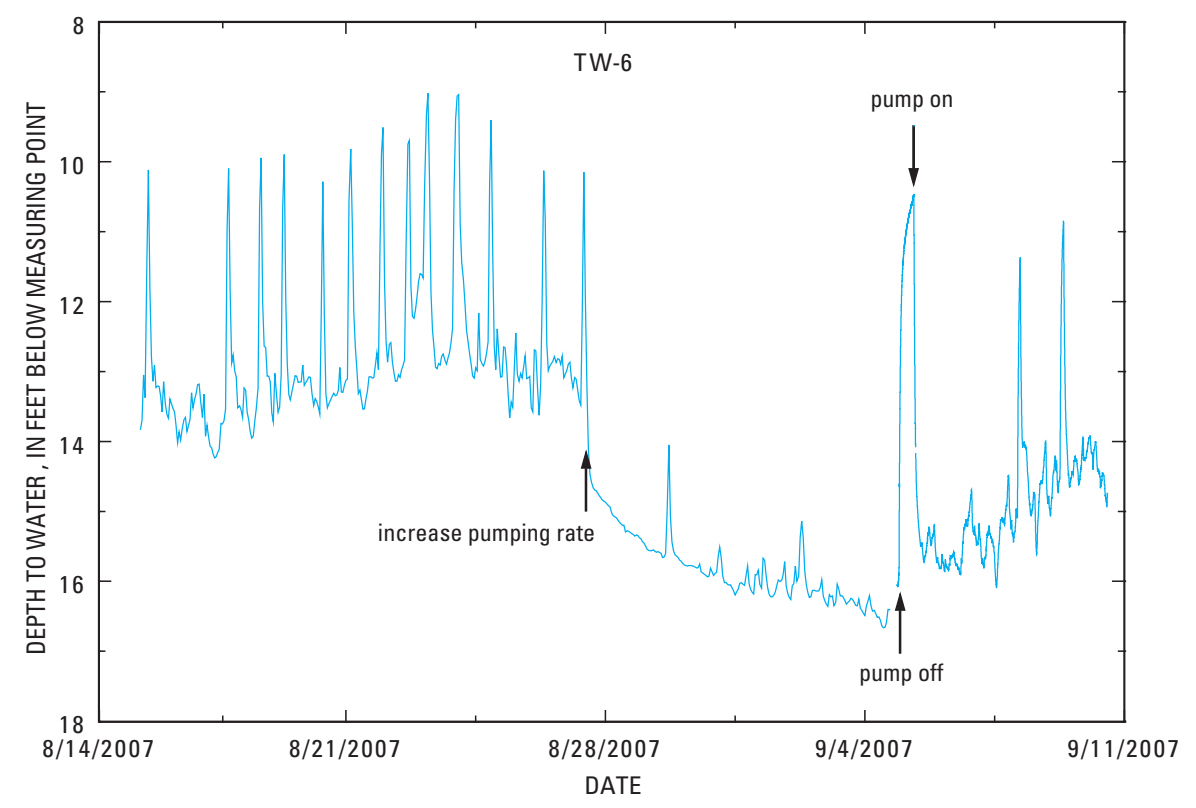

Figure 19. Water levels in observation well TW-6, United Water well field, Pootatuck River Basin, Newtown, Connecticut. Location of observation well TW-6 shown in figure 6.

Groundwater levels in the three available observation wells were monitored during the test. Water levels also were monitored inside and outside the six streambed piezometers installed in the Pootatuck River and at the two staff gages upstream and downstream from the production well (fig. 6). No precipitation was recorded from August 27 to September 5, 2007; 7 days prior to and throughout the test.

\section{Groundwater and Surface-Water-Level Monitoring}

Continuous water levels were recorded in observation wells TW-2, TW-4, and TW-6 as well as streambed piezometer SBP2C (fig. 6). The water levels recorded in observation well TW-6 and piezometer SBP2C are shown in figures 19 and 20, respectively.

Water levels in Well TW-6, located $5 \mathrm{ft}$ from Well 2, clearly shows the effects of pumping on the groundwater system, including (1) normal pumping of Wells 1 and 2 prior to August 27, 2007, (2) the change to pumping only Well 2 at a relatively constant rate, (3) the pump turn off in Well 2 on September 4, 2007, and (4) the return to normal pumping (fig. 19). Groundwater levels and stream stage were measured at the streambed piezometers to determine whether the groundwater was discharging to the stream or the stream water was being infiltrated into the groundwater. The head gradient at each piezometer indicated stream inflow to the groundwater system. The middle piezometer, SBP2C was equipped with a pressure transducer (fig. 20). When Well 2 was turned off, the water level in surface water and groundwater rose, but the infiltration continued, most likely because the recovery period was just 9.5 hours.

Because the infiltration test had to be run after dark, it was not possible to make streamflow measurements during the test; only stage data were recorded. The stage measurements for the Pootatuck River upstream and downstream from the production well are shown in figure 21. During the period of increased pumping, the stage at the upstream and downstream sites steadily decreased with a greater decrease at the downstream site. Immediately before the wells were shut down, measurements made at 3:30 and 7:50 p.m. indicate a drop in the stage at both sites (fig. 21). The discharge line from the hydrant was shut down at 7:45 p.m., and it is possible that the stream stage dropped with the cessation of the backwater condition caused by the discharge from the hydrant. No stage measurements were made immediately after the pumps were turned off, but measurements made between 5:45 and 9:00 a.m. on September 5 indicate a rise in stage at the upstream and downstream sites, presumably a delayed response to cessation of pumping. This confirms that the pumping caused some streamflow depletion within the reach between the streamflow measurement locations. It also indicates that the upstream measuring site was not outside the area of influence of the production well. It was not possible to measure further upstream because of a wetland. 

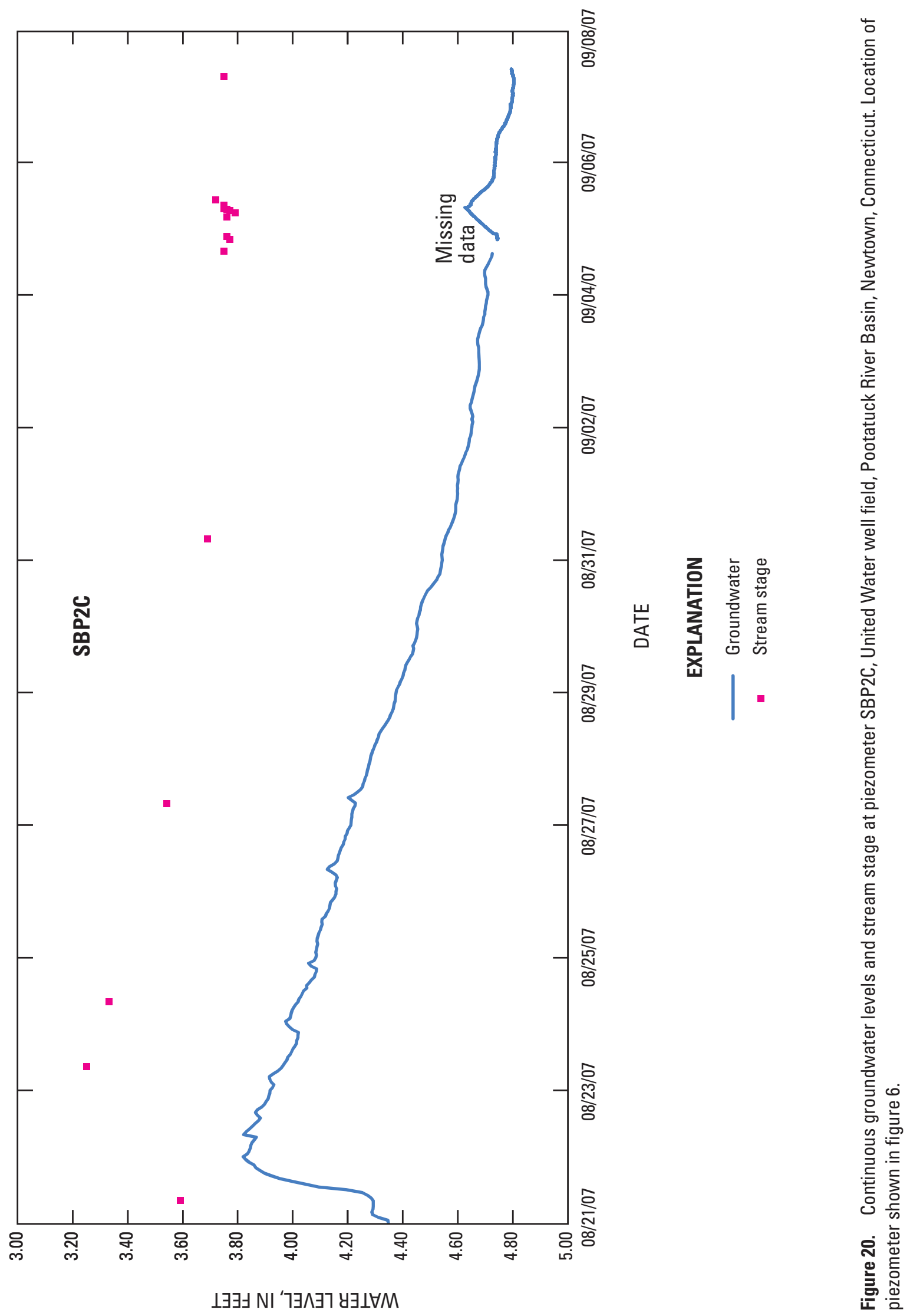


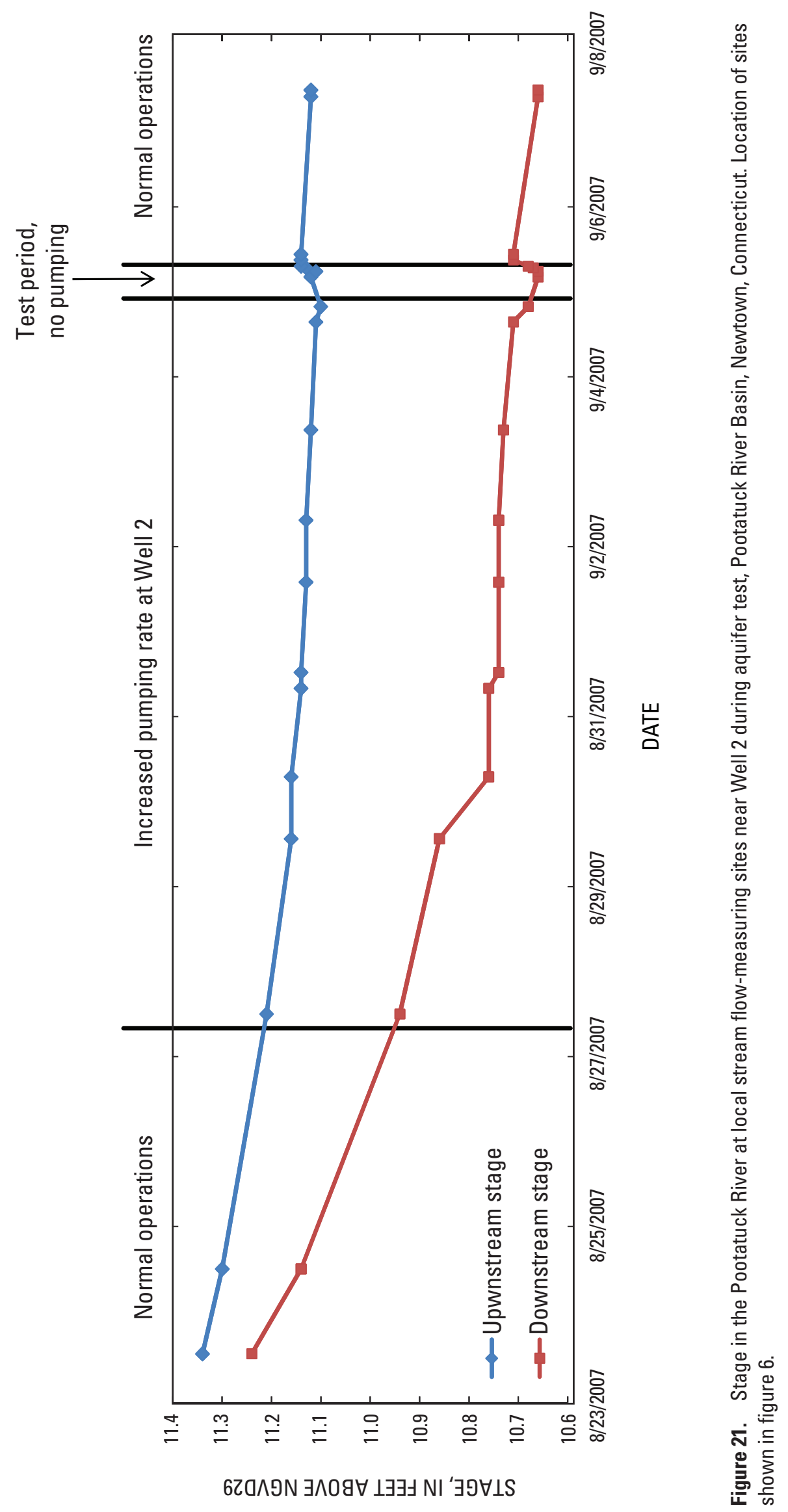




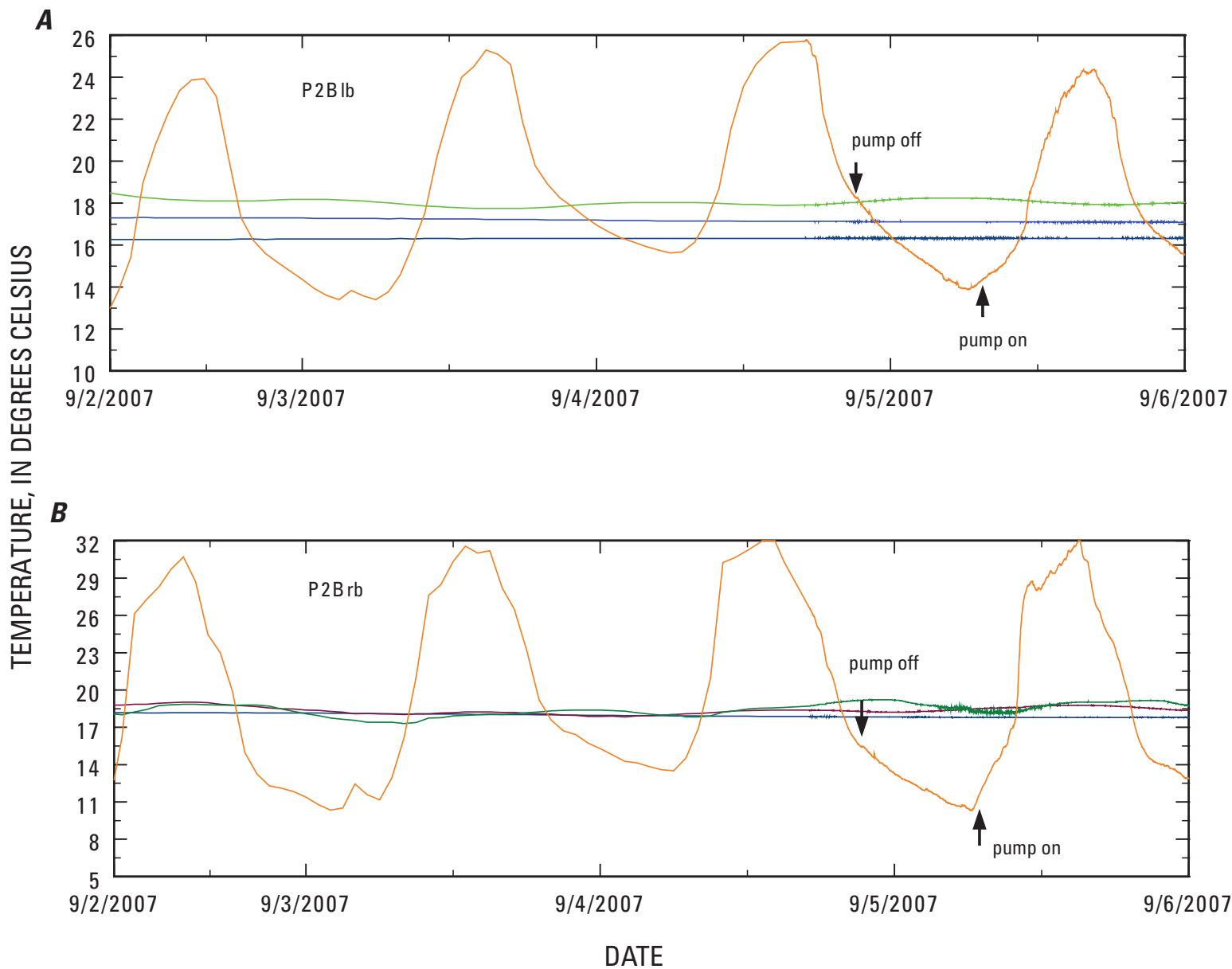

EXPLANATION

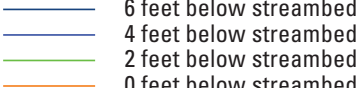

Figure 22. Temperature recorded in streambed piezometers at location B near Well $2 \mathrm{~A}, \mathrm{P} 2 \mathrm{Blb}$ (left bank) and $B$, P2Brb (right bank), Pootatuck River Basin, Newtown, Connecticut. Location of piezometers shown in figure 6.

\section{Temperature Monitoring}

Groundwater temperature was measured in all streambed piezometers at varying intervals prior to the aquifer test and in all piezometers except SBP2C, which was instrumented with a pressure transducer, during the aquifer test. Temperatures recorded in piezometers SBP2Blb, SBP2Brb, SBP2Dlb and SBP2Drb are shown in figures 22 and 23. When Well 2 was pumping, the temperatures of the groundwater at 2, 4, and $6 \mathrm{ft}$ below the streambed were relatively constant and similar to each other and approximately equal to the average temperature of the stream ( $0 \mathrm{ft}$ below streambed). The temperature 2 $\mathrm{ft}$ below the streambed fluctuates with the same period as the stream water indicating stream inflow. The temperature pattern appears to have a delay of almost a day, possibly indicating that the streambed is retarding the flow of water. When Well 2 was turned off, the temperature $2 \mathrm{ft}$ below the streambed in the piezometer near the right (near) bank of the stream at both locations became less similar to the average temperature of the surface water.

\section{Historical Aquifer Tests}

Several aquifer tests have been conducted at the United Water well field in the past (Kevin Moran, United Water 


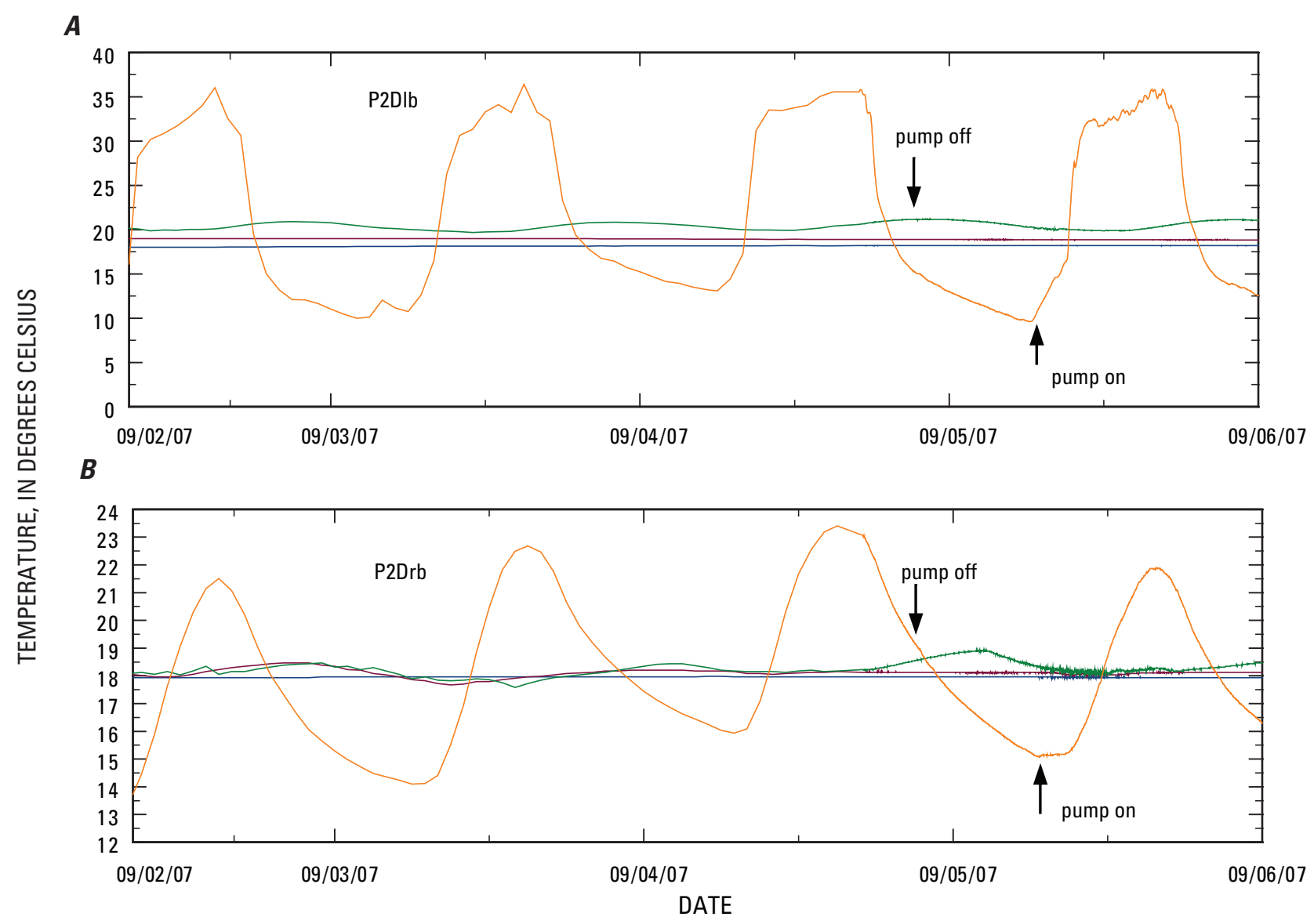

\section{EXPLANATION}

6 feet below streambed

4 feet below streambed

2 feet below streambed

0 feet below streambed

Figure 23. Temperature recorded in streambed piezometers at location D near Well $2 \mathrm{~A}, \mathrm{P} 2 \mathrm{Dlb}$ (left bank) and $B$, P2Drb (right bank), Pootatuck River Basin, Newtown, Connecticut. Location of piezometers shown in figure 6.

Company, written commun., 2006). An aquifer test was conducted on two 10-in. diameter test wells installed at the current locations of production Wells 1 and 2 at the United Water well field in November 1979 by the Stephen B. Church Company to determine the safe yield of the aquifer. Six 2.5-in.-diameter observation wells (TW-1, TW-2, TW-3, TW-4, TW-5, and TW-6, fig. 6) were installed to monitor groundwater levels during the aquifer test. Another aquifer test was conducted at the United Water well field in June 1981 by the Layne New York Company, Inc., for an aquifer mapping study using a new, 16-in.-diameter primary production Well 2 (at the same location as the 10 -in. well 2).

\section{Analysis of Historical Aquifer Test at United Water Well Field}

The short-duration, reverse aquifer test conducted on Well 2 at the United Water well field did not allow for calculation of transmissivity of the aquifer. Therefore, data from the June 1981 test, with Well 2 pumping at an average of $703 \mathrm{gal} / \mathrm{min}$, were used to calculate transmissivity and hydraulic conductivity for use in the groundwater-flow model of the current study (table 7). Data from the test in November 1979 were not used for typical aquifer test analysis because both wells were pumping and there was considerable interference between them. 


\section{Development of the Groundwater-Flow Models}

Numerical models synthesize existing hydrogeologic information into an internally consistent, mathematical representation of a real system or process and thus are useful tools for testing and improving conceptual models or hypotheses of groundwater-flow systems (Konikow and Reilly, 1999). Three-dimensional, numerical groundwater-flow models were developed for the Pootatuck River Basin for the purpose of (1) synthesizing the available hydrogeologic data including aquifer tests conducted in Newtown, Connecticut; (2) determining areas contributing recharge to five simulated production wells in Newtown for steady-state conditions; and (3) assessing the effect of three potential future scenarios on the distribution and amount of recharge available to the groundwater system and the associated effect on base flow in streams.

\section{Development of a Conceptual Model of the Pootatuck River Basin}

The conceptualization of how and where water enters, moves through, and leaves the aquifer is critical to the development of an accurate flow model (Reilly, 2001). Groundwater flow in the Pootatuck River Basin is in an aquifer system that consists of bedrock formations as well as the unconsolidated material that overlies the bedrock. The production wells in Newtown draw water from the productive unconsolidated stratified glacial deposits that lie in the center of the bedrock valley.

Water levels in shallow water-table aquifers often are a subdued replica of the land surface; therefore, the lateral boundaries of the aquifer system can be approximated by the surface-water basin divide of the Pootatuck River (fig. 24). In some basins, differences may exist between the surfacewater and groundwater basin divides, especially where there are large changes in aquifer hydraulic properties or large groundwater withdrawals near an aquifer boundary. However, these effects were assumed not to be significant in the Pootatuck River Basin because the production wells are not near the watershed divide.

The lower boundary of the aquifer system was set as an imaginary surface (at about $80 \mathrm{ft}$ below the bottom of the valley-fill material) that is assumed to separate water that discharges to the Pootatuck River from water that leaves the basin and discharges elsewhere or is stagnant. Under this modeling schematic, the aquifer system includes some water in the bedrock and all water in the overlying glacial deposits. Any further characterization of the deeper, regional flow system can be considered only in a hypothetical sense (Starn and others, 2000). The thickness of this layer in the uplands was varied during the modeling process; however, it is the interface between the bedrock and the overlying sediments that is important and not the thickness of the bedrock layer.
Precipitation is the source of all water in the basin. Some of the precipitation is lost to evaporation and transpiration by plants; the remainder infiltrates the ground and recharges the groundwater system at the water table. There is no lateral inflow to the groundwater system in the basin-scale model because the model boundaries coincide with the basin boundaries; however, only a part of the boundaries of the wellfield-scale models coincides with the basin boundaries. (The boundaries of the well-field-scale models will be discussed later.) The groundwater leaves the basin through groundwater outflow across the downgradient model boundary, groundwater evapotranspiration, groundwater discharge to streams, or by production well withdrawals.

\section{Development of Numerical Models}

The numerical models developed for simulating groundwater flow in the Pootatuck River Basin used the USGS three-dimensional, finite-difference groundwater-flow computer program MODFLOW-2000 (Harbaugh and others, 2000). A USGS particle-tracking program (MODPATH) developed by Pollock (1994) was used with MODFLOW to determine the areas contributing groundwater recharge to the simulated production wells.

Groundwater-flow models for the Pootatuck River Basin were developed at the well-field scale and basin scale (fig. 24). The well-field-scale models, one at each of the Fairfield Hills and United Water well fields, were run in transient mode to simulate the conditions during aquifer tests. These models used data from the aquifer tests to determine hydraulic conductivity values for the aquifer materials in the vicinity of the production wells. All water withdrawn from simulated wells was removed from the groundwater system. This was somewhat different from the conditions of the aquifer tests because some, if not all, well withdrawals were discharged to the river downstream from the well fields.

The well-field-scale models also were run in steady-state mode to determine areas contributing recharge to the production wells. The basin-scale model was run in steady state to determine the effect of future development on the distribution and amount of recharge available to the groundwater system and the associated effect on base flow in streams, that is, the water budget. All simulated well withdrawals were removed from the groundwater system in the steady-state models. This is not representative of long-term average annual conditions because some of the water withdrawn from the production wells is distributed to customers who then discharge it back to the groundwater system through onsite septic systems. Thus, these models represent a condition with less recharge to the groundwater system than may actually occur.

The development of the well-field-scale and basin-scale models was an iterative process: (1) a preliminary basin-scale model was developed using land surface as the starting water levels; (2) the well-field-scale models were developed from the preliminary model and were calibrated using aquifer-test 


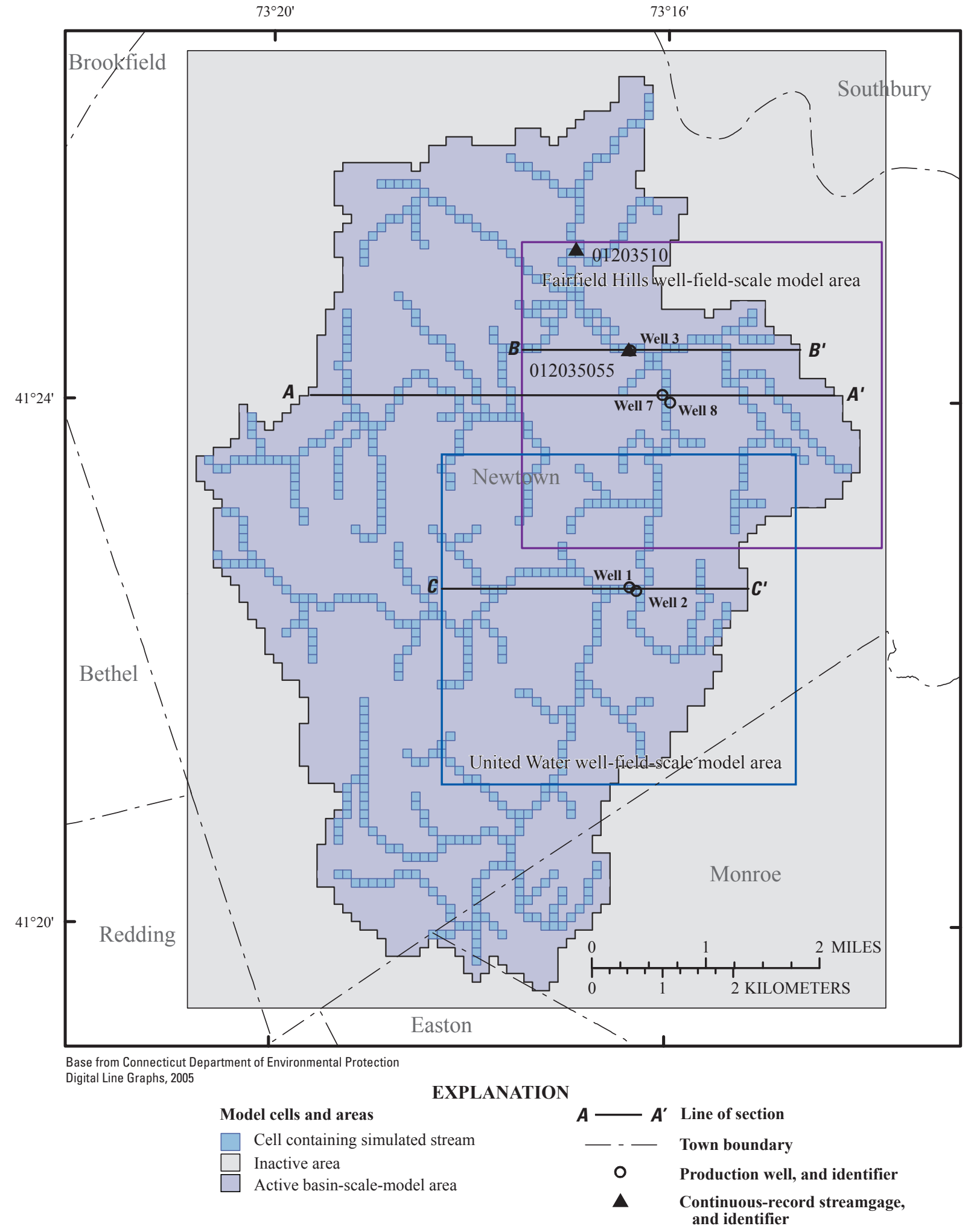

Figure 24. Extent of well-field- and basin-scale models in the Pootatuck River Basin, Newtown, Connecticut. 
data; (3) values from the well-field-scale models were used as input data for the basin-scale model, which was then calibrated; (4) any changes to modeled input values from the basin-scale model were reincorporated into each well-fieldscale model as were the values from the basin-scale model of water level at the boundaries; and (5) the latest results of each well-field-scale model were examined to determine if they were a reasonable representation of the hydrologic conditions. Steps 3 through 5 were repeated until the well-field-scale and basin-scale models were internally consistent and calibrated.

Because the models were developed iteratively, this report discusses the three models together. This first section gives information common to all three models, followed by a discussion of the setup and calibration of each of them. The next major sections give the results of model simulations - the delineation of areas contributing recharge to production wells, the interaction between groundwater and surface water, and the effect of future recharge conditions.

\section{Model Discretization and Boundaries}

A finite-difference model grid consists of a series of orthogonal model cells in which user-specified inputs of hydraulic parameters, model stresses, and boundary conditions are varied spatially. A detailed discussion of grid discretization, boundary conditions, and the use of finite-difference equations to simulate groundwater flow is presented in McDonald and Harbaugh (1988).

The Pootatuck River Basin includes large areas of upland till and bedrock (fig. 4). Modeling investigations in areas that include upland till and bedrock areas surrounding an aquifer comprised of stratified glacial deposits typically focus just on the aquifer materials that fill the valley. These models do not explicitly simulate the upland areas but rather specify the recharge that enters the aquifer from the upland areas as enhanced recharge at the contact of the till and stratified glacial deposits (Dickerman and others, 1997; Barlow and Dickerman, 2001; DeSimone and others 2002; Granato and others, 2003; Friesz, 2004). This approach is used to avoid the numerical instabilities that result from simulating steeply sloping, thinly saturated deposits, such as the upland till and bedrock areas of higher elevation that surround the stratified glacial deposits of the lowland Pootatuck River Basin. The drawback to this approach, however, is that the upland till and bedrock areas are not part of the active modeled area, and application of the recharge areally and throughout the thickness of the aquifer is somewhat arbitrary.

A different approach to model layers was used in an investigation in the Upper San Pedro Basin, Arizona and Mexico (Pool and Dickinson, 2007). It included a spatiallycontinuous active layer that represented both the bedrock that underlies the valley-fill sand and gravel deposits and the bedrock and till of the surrounding upland hillsides. The valley-fill sand and gravel deposits were simulated with overlying model layers that covered a smaller spatial extent. This approach was used in both the basin-scale and well-field-scale models of the Pootatuck River Basin; the stratified glacial deposits were simulated as layers 1 and 2, and both the upland till and bedrock areas and the bedrock beneath layer 2 were simulated as layer 3. The benefit of this approach is it allows for simulation of the upland till and bedrock areas and a more realistic representation of flow from these upland areas to the lowland stratified glacial deposits (fig. 25).

All water enters and leaves the groundwater-flow model through the hydrologic boundaries and the boundary conditions control that flow. Where possible, the lateral boundaries coincide with the basin divide and, therefore, are no-flow boundaries. The upper boundary of the models is the water table, which is a free-surface boundary that receives areally-variable recharge from precipitation. The lower boundary of the model is bedrock that underlies the entire study area. Streams were modeled as "head-dependent flow boundaries" using the Streamflow-Routing Package (Prudic, 1989) of MODFLOW-2000. This package simulates the hydraulic interaction between the aquifer and adjoining streams and tracks the amount of water in each modeled stream reach. Modeled streams were divided into reaches, corresponding to individual model cells and segments, which are groups of reaches that are connected in downstream order (Prudic, 1989).

In the model, water may flow either from the aquifer to the stream (groundwater discharge) or from the stream into the aquifer (stream inflow). The movement of water across the streambed is calculated by multiplying the specified streambed conductance by the difference between the stream stage and the water level in the underlying aquifer. During the simulation, streams may go dry when stream inflow to the aquifer exceeds inflow to the stream reach from upstream reaches. Because the simulation is of groundwater only, flows in modeled streams represent only base flow, the groundwater component of streamflow. The component of streamflow that results from direct or storm runoff is not included in the model simulations.

\section{Model Calibration}

Model calibration is the process by which modifications are made to the initial model-input parameters to make the model output more closely match observed water levels and base flows (Reilly and Harbaugh, 2004). Parameters adjusted during calibration of the models include hydraulic conductivity of the aquifer and of the streambed and specific yield.

The hydraulic property values reported by Haeni (1978) were used as a guide for the initial values used in the groundwater-flow model. These values were for general categories of glacial materials and were not subdivided into the individual geologic units denoted on the surficial materials map (Stone and others, 1992). Therefore, assigning a different hydraulic value to each geologic unit could not be justified. During calibration, simulated water levels were used to combine adjacent individual geologic units of similar description into larger, more generalized areas of uniform 

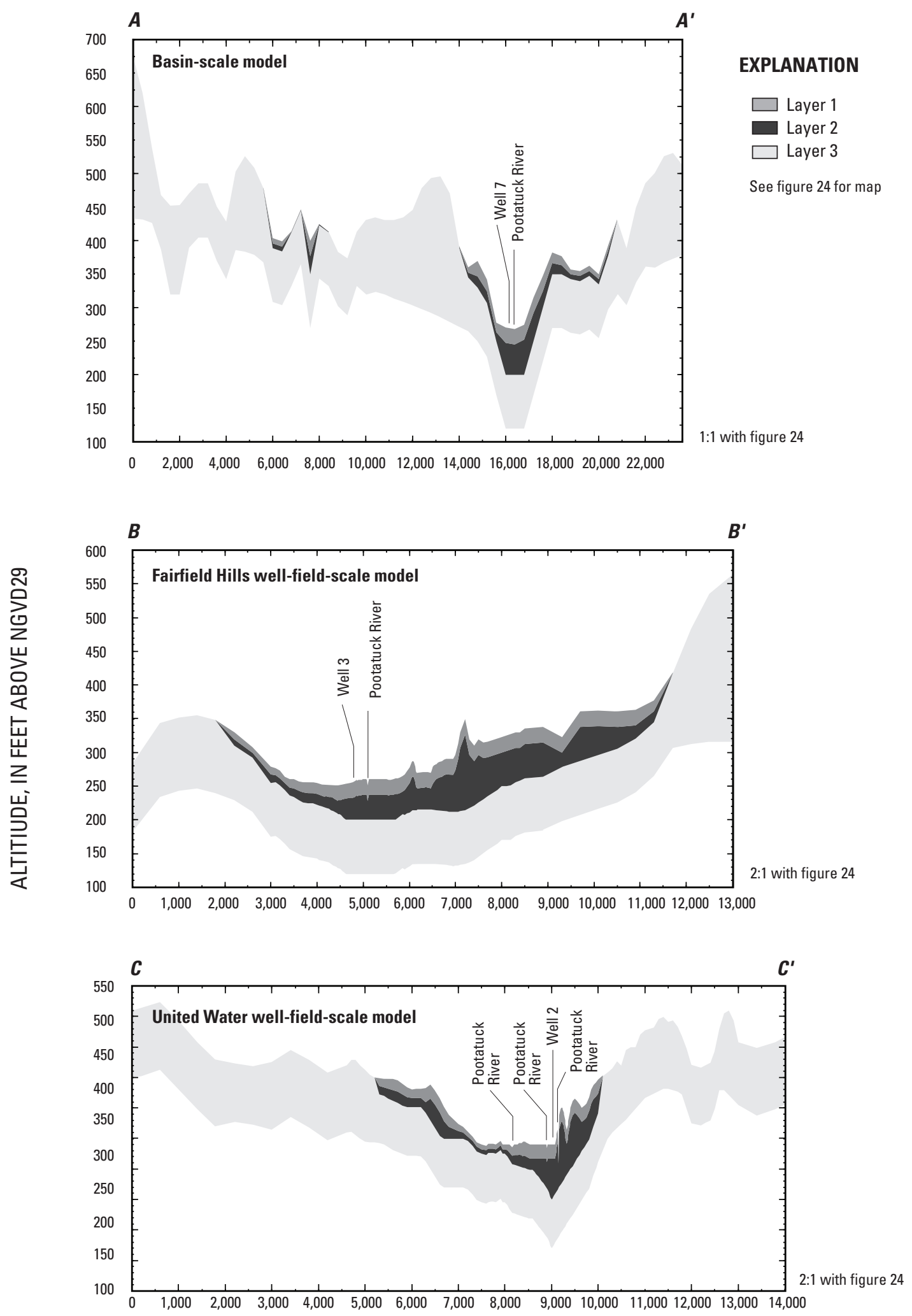

LINEAR DISTANCE, IN FEET

Figure 25. Cross sections showing model layers, Pootatuck River Basin, Newtown, Connecticut. Locations shown in figure 24. 
hydraulic properties to which hydraulic conductivity values could be assigned. This resulted in three principal hydrologic units - coarse-grained glacial deposits, which consist of sands and gravels; fine-grained deposits, which consist of till and fine-grained stratified deposits (silts and clays); and bedrock. The unconsolidated materials were assumed to be consistent from land surface to bedrock, as evidenced by the stacked units mapped by Stone and others (1992). Trial and error adjustments to hydraulic conductivity in these larger areas were made until simulated water levels more closely matched observed water levels. The resulting values of hydraulic conductivity were consistent with values calculated from the aquifer-test data and also with accepted ranges of hydraulic conductivity associated with the type of geologic material present. Although the calibrated groundwater-flow model uses reasonable parameters, it is important to note that groundwater-flow models produce nonunique solutions, such that the same model-calculated response in water levels or base flows might be obtained by using different combinations of hydraulic parameters.

\section{Well-Field-Scale Models}

The purpose of the well-field-scale models was twofold: (1) to determine hydraulic conductivity values for the aquifer materials in the vicinity of the production wells, and (2) to determine areas contributing recharge to simulated wells. The Fairfield Hills and the United Water well-field-scale models (fig. 24) were run in transient mode to simulate the aquifer tests and in steady-state mode to determine recharge areas to the simulated production wells. Features common to both well-field-scale models are summarized first.

Each model grid had a variable cell size that was centered on the production and observation well locations. The grid spacings of the cells were $10,50,100$, and $400 \mathrm{ft}$, increasing in size from the vicinity of the production and observation wells to the model boundary. The well-field-scale models mostly covered the stratified glacial deposits.

In each well-field-scale model, three layers were used to represent the primary hydrogeologic units, based on the surficial materials map (fig. 4) and the bedrock surface map (fig. 3). The stratified glacial deposits were divided into model layers 1 and 2. The minimum thickness for combined layers 1 and 2 was $15 \mathrm{ft}$. Horizontal hydraulic conductivity values varied spatially and reflected the type of material present; vertical hydraulic conductivity was specified at one tenth of the horizontal hydraulic conductivity. Initial hydraulic conductivity values were based on those determined during the aquifer tests, those used in a previous groundwater model of the Pootatuck River Valley (Haeni, 1978), and the surficial materials map (fig. 4). The spatial extent of the active cells in layers 1 and 2 were identical and coincided with the extent of the sand and gravel in the stratified glacial deposits. The active extent of layer 3 was greater than that of layers 1 and 2 and represented the bedrock underlying the valley-fill deposits and the till-covered upland areas (fig. 4) that occur within the Pootatuck River Basin. Layers 1 and 2 were specified as convertible between confined and unconfined groundwater-flow conditions and layer 3 was specified as a confined layer.

The well-field-scale models covered only part of the Pootatuck River Basin. Where possible, the model boundaries were chosen to coincide with the basin boundary and, therefore, were no-flow boundaries. Other boundaries were set far enough away from the production wells so they would not affect the aquifer response to the wells and so the modeled area would include the full extent of the areas contributing recharge to those wells (fig. 24). Water entered the modeled area across these arbitrarily set lateral boundaries and was simulated using the Constant-Head Boundary feature of MODFLOW-2000 (Harbaugh and others, 2000). Initial water levels specified along these boundaries were determined from the preliminary basin-scale model, and final water levels were determined from the basin-scale model as part of the iterative process described above. Recharge, specified as one-half the precipitation, was added at the times it rained during the test.

Values of base flow in the Pootatuck River and its tributaries where they entered the modeled area were estimated using equations developed by Ahearn (2010). These equations calculate a specified duration flow at an ungaged site in separate "bioperiods" that represent the different flow needs of the aquatic ecosystem at certain times of the year. The flow duration for the Rearing and Growth bioperiod (July through October) at the nearby Pomperaug River streamgage was determined for the dates of each of the aquifer tests, and that duration flow was estimated at the points where streams entered the well-field-scale models. Basin characteristics used in the regression equation were total drainage area and the percent of area underlain by coarse stratified deposits.

Initial calibration of the well-field-scale models was accomplished by comparing observed drawdown and baseflow values, measured during the aquifer tests, and the simulated values. Simulated drawdown values were calculated as the difference between the simulated water levels during the aquifer tests and the simulated water levels that represented steady-state conditions just prior to the start of the aquifer test.

\section{Fairfield Hills Well-Field-Scale Model}

The transient well-field-scale model of the Fairfield Hills area is centered on production Wells 3 and 7 in the northern part of Newtown. The total active modeled area is about $6.2 \mathrm{mi}^{2}$ and consists of 222 rows and 234 columns (fig. 26). Thickness of layer 1 ranged from 7.5 to $23 \mathrm{ft}$, thickness of layer 2 ranged from 7.5 to $138 \mathrm{ft}$, and thickness of layer 3 was $80 \mathrm{ft}$ (fig. 25, cross section B-B' shown on fig. 27). Stream reaches in the Fairfield Hills model contained 1,679 model cells grouped into 39 stream segments. In the stratified glacial valley-fill deposits, stream cells were assigned to layer 1 , and in the upland till and bedrock areas, stream cells were assigned to layer 3, the uppermost layer in that area (fig. 27). The area of the streambed in each modeled stream cell (used 


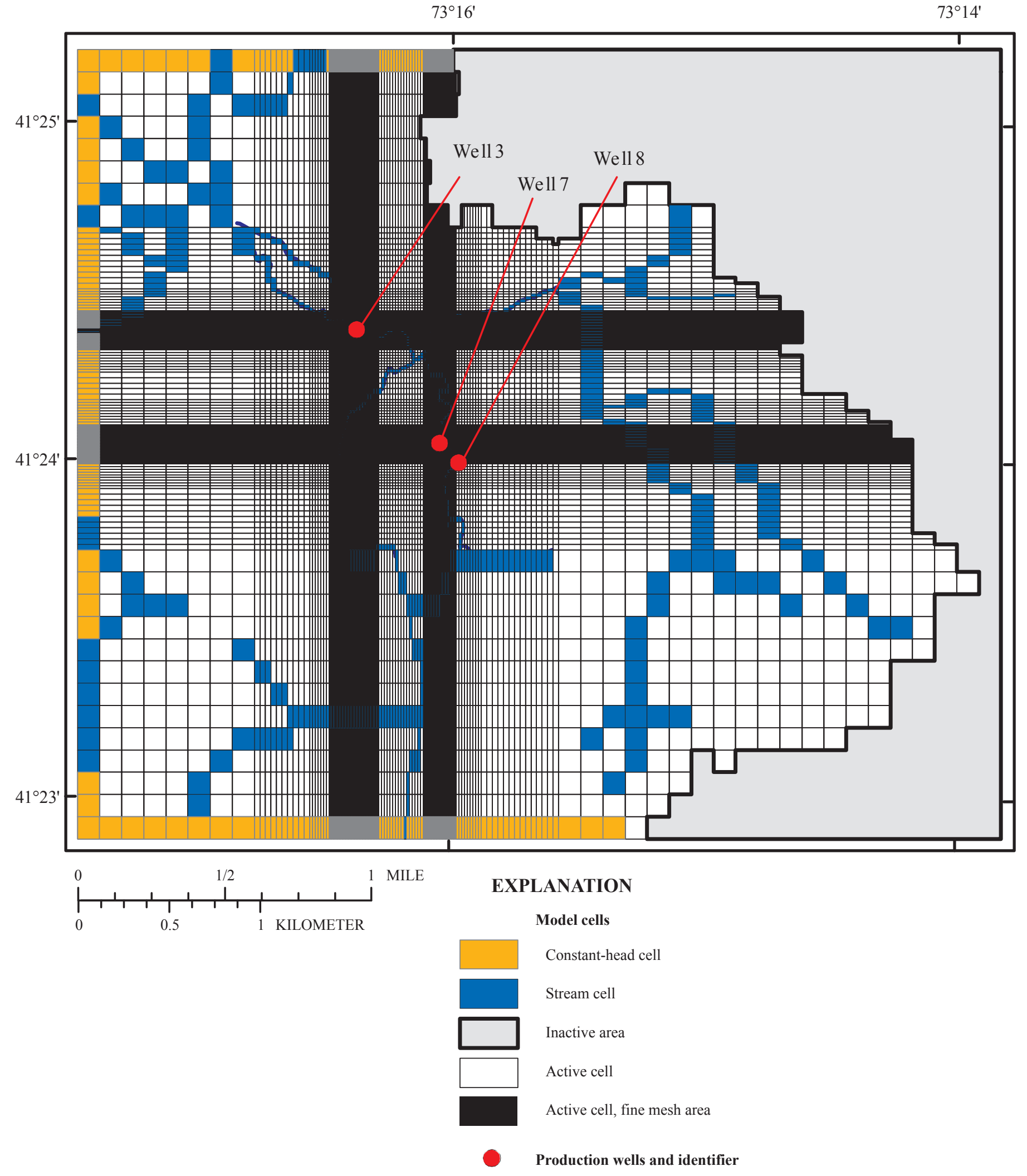

Figure 26. Fairfield Hills well-field-scale model, Pootatuck River Basin, Newtown, Connecticut. 
$73^{\circ} 16^{\prime}$ $73^{\circ} 14^{\prime}$

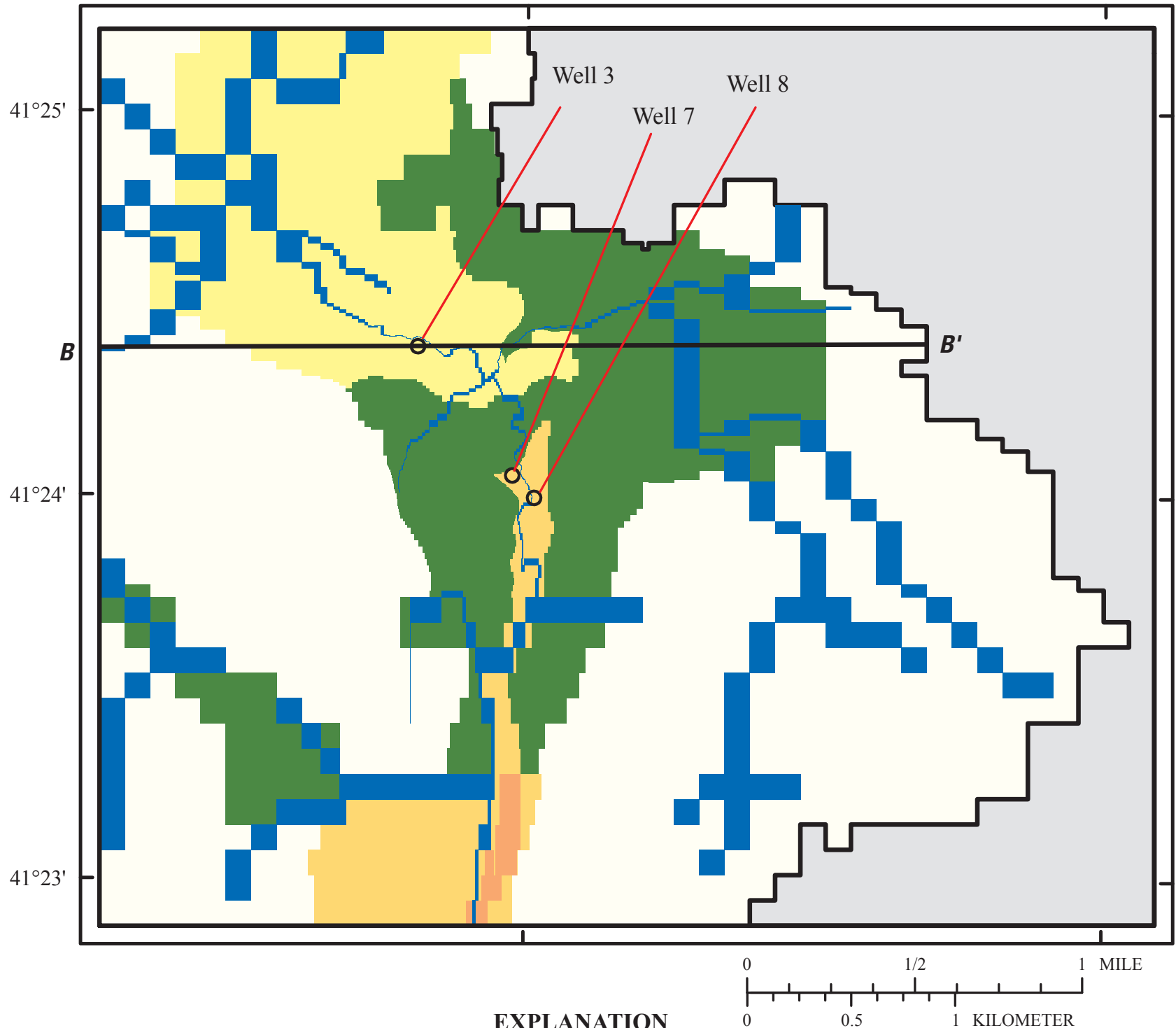

Stream cells, inactive cells

Simulated hydraulic conductivity

Feet per day, layer 1 and layer 2

Stream cell

$$
18,16 \text { (layer 2) }
$$

Line of section $\boldsymbol{B}-\boldsymbol{B}^{\prime}$ (See fig. 25)
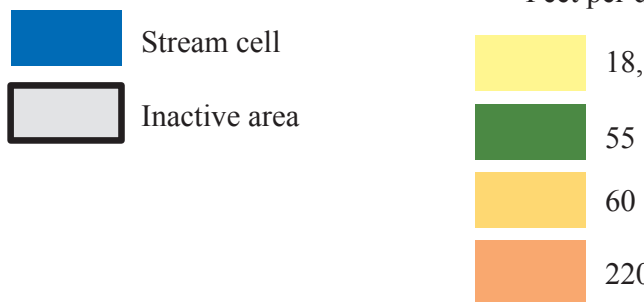

O Production well

55

60

220

Feet per day, layer 3

3

Figure 27. Hydraulic conductivity in the Fairfield Hills well-field-scale model, Pootatuck River Basin, Newtown, Connecticut. 
to calculate streambed conductance) was determined using the length of stream reach in each modeled cell as the cell length in the downstream direction and the width of the stream as a function of the stream order. The streambed was assumed to be $1 \mathrm{ft}$ thick.

\section{Simulation of Aquifer Test}

The transient model of the Fairfield Hills well field used data from the aquifer test conducted from July 23 to August 6, 2007, at production Wells 3 and 7. To simulate the various stages of the aquifer test - shut off, pumping, and recovery - the groundwater model had a total of 145 stress periods and covered the period July 25 through August 6, 2007. The simulation began with a steady-state stress period equilibrating the initial water levels to a steady-state solution, followed by 144 transient stress periods representing the different stresses - pumping rates and recharge - during the aquifer test. Hourly stress periods, each with a single time step, were used to simulate the rapid water-level changes at the beginning and end of the pumping part of the aquifer test. At other times when the water level was more stable, stress periods were 4 or 8 hours in length with an hourly time step.

Simulated production wells were assigned to layer 2, and the pumping rates used in the simulation were those measured at specific times during the aquifer test; each pumping rate in the model was held constant until the time of the next pumping-rate measurement. The pumping rate at Well 3 varied from 100 to $140 \mathrm{gal} / \mathrm{min}$ and at Well 7 from 438 to $465 \mathrm{gal} / \mathrm{min}$. Flow in the Pootatuck River where it crossed the upgradient (southern) boundary of the model was estimated at $4.36 \mathrm{ft}^{3} / \mathrm{s}$, assuming a 50-percent flow duration in the Rearing and Growth Bioperiod (Ahearn, 2010). Flows in Deep Brook, Tom Brook, and an unnamed tributary that enters the Pootatuck River from the east were estimated at 1.20, 0.27 , and $0.11 \mathrm{ft}^{3} / \mathrm{s}$, respectively; each of these tributaries enters the Pootatuck River downstream from the well field and downstream from the Berkshire streamgage (012035055 on fig. 24).

\section{Model Calibration and Hydraulic Properties}

Water levels measured in the production well and in the observations wells during the aquifer test were used for model calibration of the transient model. Figure 5 shows locations of the pumping and observation wells. Because of the limited duration of data available for this one transient event, only streambed conductance, hydraulic conductivity, and storage values were varied during the model calibration process. The water levels specified at the boundaries of the model were not changed during the initial calibration process but later were updated with values from the basin-scale model. The final calibrated value for vertical hydraulic conductivity of the streambed was $2 \mathrm{ft} / \mathrm{d}$, which was used to calculate streambed conductance.

Hydraulic conductivity values were adjusted through trial and error until the simulated water levels at the individual pumping and observation wells matched the observed water levels as closely as possible. The changes were made to groups of cells that corresponded to different geologic materials, as denoted on the surficial materials map (fig. 4). There were four hydraulic conductivity zones in layers 1 and 2 (fig. 27, table 9) and one in layer 3. Calibrated values of specific yield in layers 1 and 2 were 0.15 where hydraulic conductivity was less than $30 \mathrm{ft} / \mathrm{d}$ and 0.25 where hydraulic conductivity was greater than or equal to $30 \mathrm{ft} / \mathrm{d}$. Specific storage was 0.00001 in all layers.

Simulated and observed water levels from the calibrated model at the 10 observation wells and 2 production wells in the Fairfield Hills well field are shown in figures 28 and 29. Visual comparison of simulated and observed water levels shows the initial water-level decline at the start of pumping and the transition period into aquifer-test pumping conditions match reasonably well as do the transition period to nonpumping (recovery) conditions toward the end of the aquifer test. Water levels in Well 7 showed the best match.

Simulated and observed water levels were compared in four ways: (A) the difference at midnight on July 31, 2007 (about half way through the aquifer test); (B) the mean absolute error (the mean of the absolute value of the residuals); (C) the median error of synchronous pairs (simulated and observed water levels with the same date and time) during the period July 26 through August 6, 2007 (table 10); and (D) as plots of simulated residuals (the difference between observed and simulated water levels) compared to simulated water levels and observed compared to simulated water levels (fig. 30).

Simulated and observed water levels at Wells 3 and 7 matched reasonably well with mean absolute errors of 1.3 and $0.4 \mathrm{ft}$ for Wells 3 and 7, respectively (table 10B). Based on median error, the best overall matches between simulated and observed water levels were at Well 3 and its associated observation wells with median errors that ranged from -1.2 to $-0.2 \mathrm{ft}$; median errors for Well 7 and associated observation wells ranged from -1.5 to $+3.4 \mathrm{ft}$ (table $10 \mathrm{C}$ ). Two observation wells (NT-85 and NT-94) associated with Well 7 had the worst median errors, -1.5 and $3.4 \mathrm{ft}$, respectively. Observation well NT-94 was located near a mapped geologic contact and this relatively large median error could be because of differences in aquifer properties between the units; however, data were insufficient to specify more precisely different properties for the various mapped geologic units.

Model calibration included a determination of the mean of the residuals and the mean absolute error. Ideally, the mean of the residuals should be randomly distributed and close to zero, indicating no bias in the results and the mean absolute error should be less than 5 percent of the total range in the water-level measurements used for model calibration (Anderson and Woessner, 1992). Figure 30 shows the residuals of simulated and observed water levels of synchronous pairs at the Fairfield Hills and United Water well fields. The residuals are all less than $5 \mathrm{ft}$ and are distributed about the zero line (fig. 30A) indicating a good fit between the observed and simulated transient water levels. The data all lie about the line of 1:1 slope (fig. 30B), also indicating a good fit between the 
Table 9. Calibrated hydraulic parameters of the Fairfield Hills well-field-scale model, Pootatuck River Basin, Newtown, Connecticut.

$[\mathrm{ft} / \mathrm{d}$, feet per day]

\begin{tabular}{|c|c|c|c|c|c|c|}
\hline \multirow{3}{*}{ Zone } & \multicolumn{6}{|c|}{ Hydraulic conductivity (ft/d) } \\
\hline & \multicolumn{2}{|c|}{ Layer 1} & \multicolumn{2}{|c|}{ Layer 2} & \multicolumn{2}{|c|}{ Layer 3} \\
\hline & Horizontal & Vertical & Horizontal & Vertical & Horizontal & Vertical \\
\hline Valley-fill sediments near Well 7 & 55 & 5.5 & 55 & 5.5 & \multirow{2}{*}{3} & \multirow{2}{*}{3} \\
\hline Alluvium along river near Well 7 & 60 & 6 & 60 & 6 & & \\
\hline
\end{tabular}

observed and simulated transient water levels. All errors were within the requirements established by CTDEP for Level A mapping (State of Connecticut, 1991).

Simulated base flow was compared to the observed base flow at each of the staff gages upstream and downstream from Wells 3 and 7 and at the streamgages at Berkshire (012035055) and Sandy Hook (01203510) (fig. 5) at two times during the aquifer test: on July 28, 2007, when measured flows were at their lowest before a rain event and on August 3, 2007, immediately after the production wells were turned off. The best comparison was near Well 3 on July 28, 2007, when simulated and observed flows were identical. On August 3, 2007, the simulated flows were from 13 to 52 percent greater than the observed flows (table 11).

\section{Steady-State Model}

The well-field-scale model was run in steady state mode to determine areas contributing recharge to the production wells. A steady-state model represents long-term average base flows, which are equivalent to median annual streamflow (State of Connecticut, 1991). Although the two streamgages on the Pootatuck River, at Berkshire and Sandy Hook, were operating during the aquifer tests, data from these streamgages were not sufficient for calibration of a steady-state model. Therefore, median flow in the Pootatuck River at the Berkshire and Sandy Hook streamgages was estimated from data at the streamgage on nearby Pomperaug River (fig. 1, insert), which has operated continuously since 1932 . A relation between the two rivers was developed using concurrent flow data, and the median flow on the Pootatuck River was estimated using the long-term data at the Pomperaug River. Because the estimated flow represented natural conditions, the model was run with no wells pumping. Calibration of the steady-state Fairfield Hills model for nonpumping conditions included a comparison of estimated and simulated flows. The estimated base flow of the Pootatuck River was $20.4 \mathrm{ft}^{3} / \mathrm{s}$ at Berkshire and $28.7 \mathrm{ft}^{3} / \mathrm{s}$ at Sandy Hook. The simulated steady-state, nonpumping streamflows of 19.2 and $28.9 \mathrm{ft}^{3} / \mathrm{s}$ at Berkshire and Sandy Hook differed by 5.9 and 0.7 percent, respectively.
The only natural flow of water to the Pootatuck River Basin aquifer enters the groundwater system as recharge from precipitation. Many groundwater-flow models use a constant rate of recharge over the entire modeled area. However, the amount of recharge at a given location is a function of the physical and land-use conditions in that area. An important feature of this study was to develop a map of areallydistributed recharge representing steady-state conditions based on the surface and land-cover conditions in the basin. The distribution of recharge was based on a statistical relation between various basin characteristics and recharge that was developed for the nearby Pomperaug River Basin (Bjerklie and others, in press). The relation was developed using a precipitation runoff modeling system (PRMS) basin model, developed by the USGS (Leavesley and others, 1996; Mastin and Vaccaro, 2002). A description of the method is provided in the appendix. Using areally-distributed recharge to a groundwater-flow model allows for analysis of changes to the groundwater system caused by changing land use or climate change. The approach used in this study could be used in other basins in western Connecticut and a similar approach could be developed for any basin.

\section{United Water Well-Field-Scale Model}

The transient well-field-scale model of the United Water area is centered on production Wells 1 and 2 in the southern part of Newtown. The total active modeled area is about $7.3 \mathrm{mi}^{2}$ (fig. 31) and consists of 222 rows and 224 columns. Thickness of layer 1 ranged from 7.5 to $23 \mathrm{ft}$ and layer 2 ranged from 7.5 to $142 \mathrm{ft}$. Thickness of layer 3 was $80 \mathrm{ft}$ (fig. 25, cross section C-C' shown on fig. 32). Stream reaches in the United Water well-field-scale model contained 1,725 model cells grouped into 34 stream segments. The layering approach for active cells, stream-cell assignment, and determination of streambed area and thickness was the same as that used in the Fairfield Hills model. 

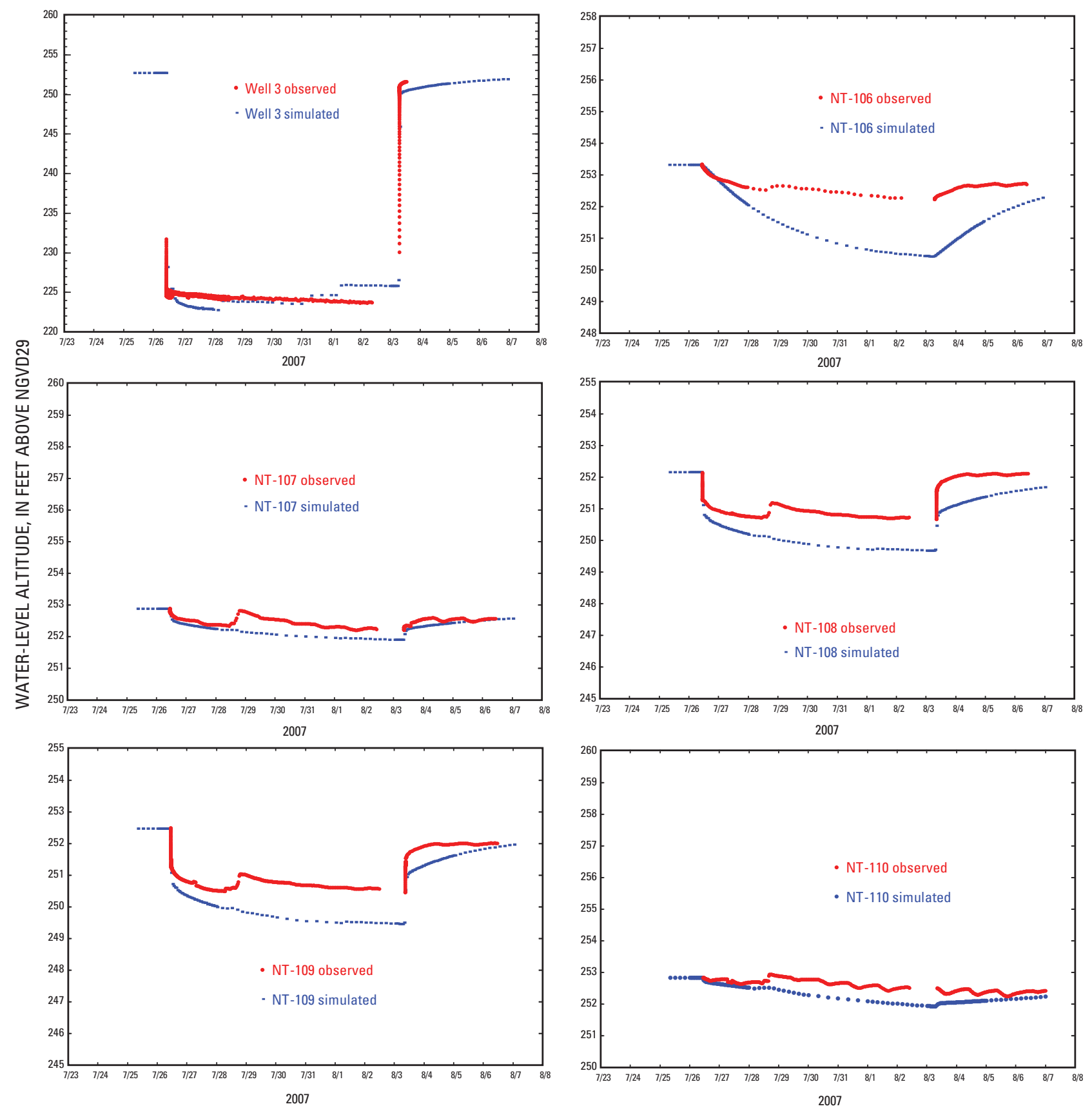

DATE

Figure 28. Simulated and observed water levels during Fairfield Hills aquifer test at Well 3, Pootatuck River Basin, Newtown, Connecticut. 

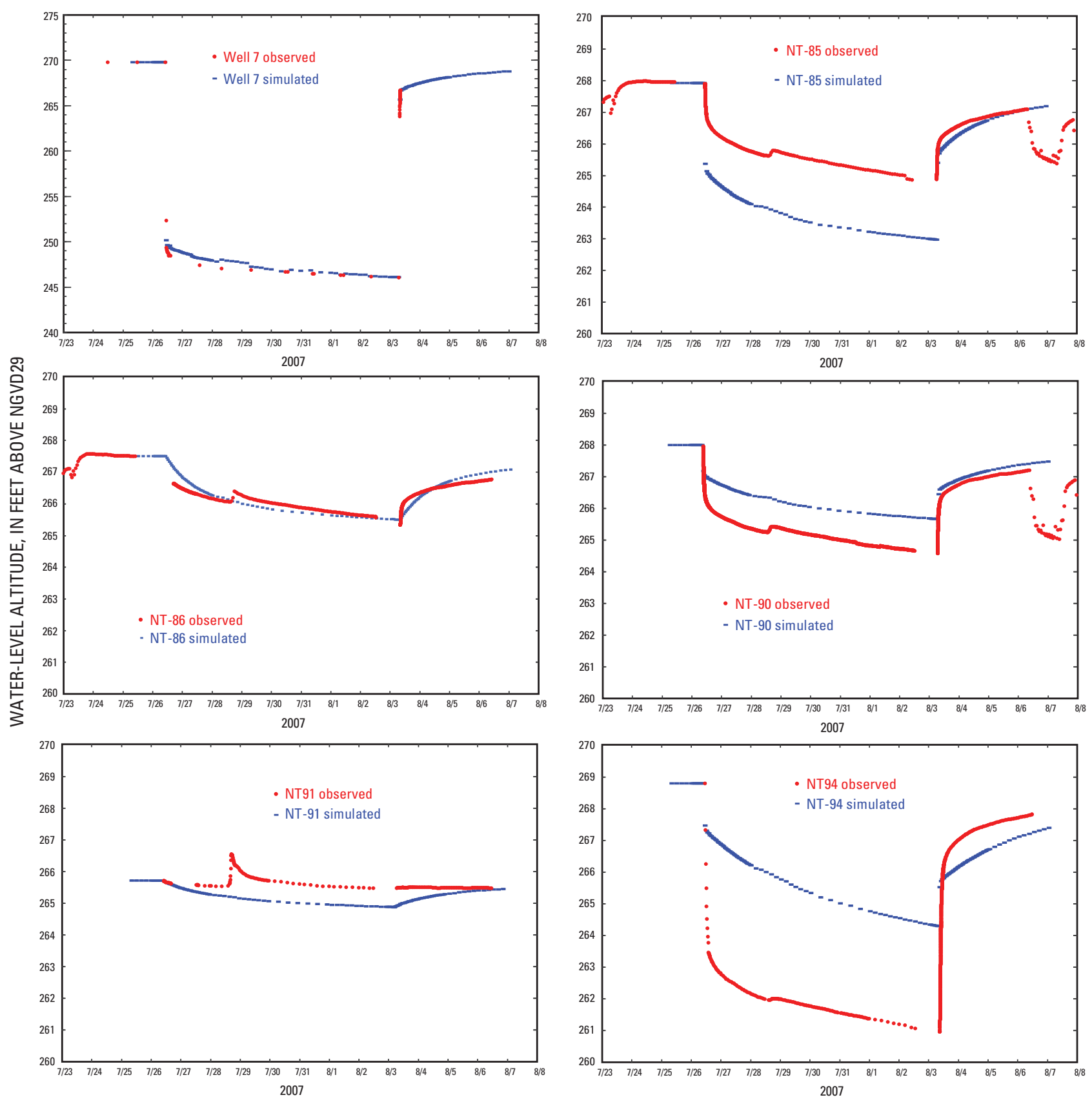

DATE

Figure 29. Simulated and observed water levels during Fairfield Hills aquifer test at Well 7, Pootatuck River Basin, Newtown, Connecticut. 


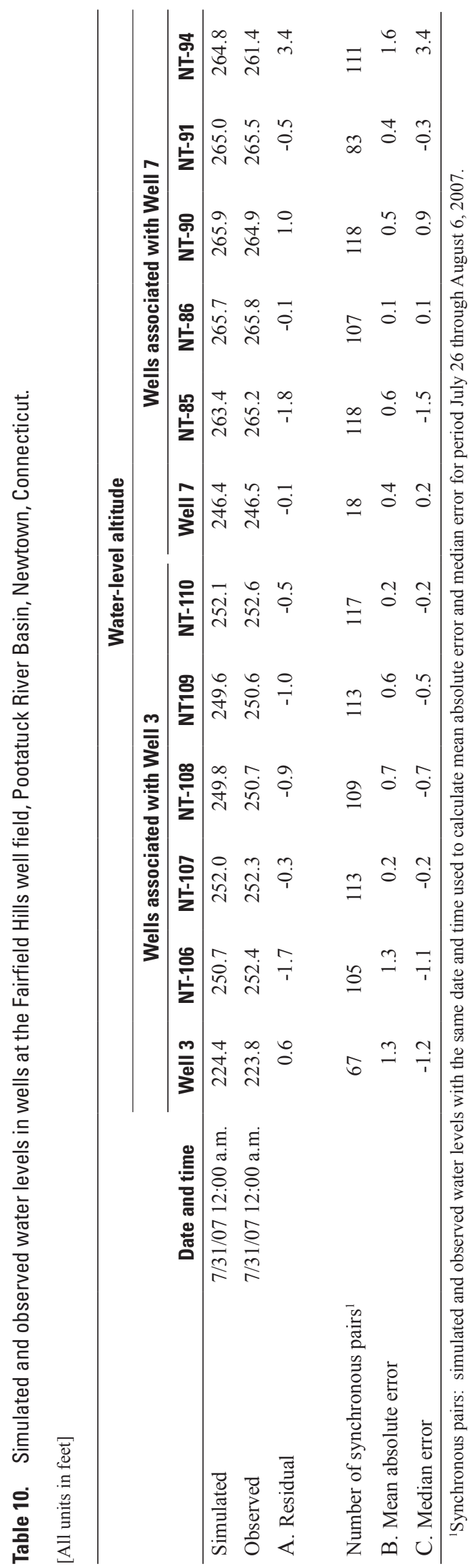




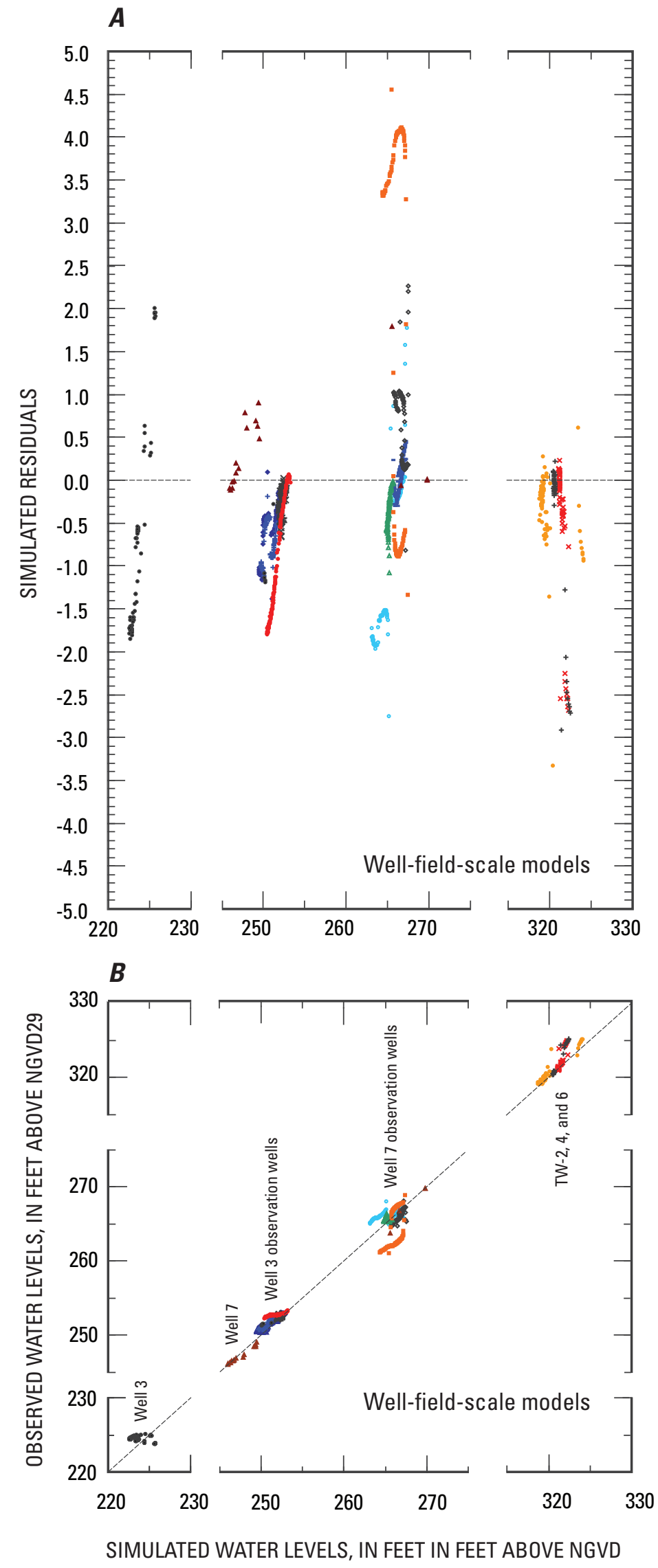

Figure 30. Comparison of simulated and observed water levels at Fairfield Hills and United Water well fields, Pootatuck River Basin, Newtown, Connecticut; $A$, simulated residuals compared to simulated water levels, and $B$, observed water levels compared to simulated water levels. Different colors represent data from different wells. 
Table 11. Simulated and observed base flow, Fairfield Hills well field, Pootatuck River Basin, Newtown, Connecticut.

[ $\mathrm{ft}^{3} / \mathrm{s}$, cubic feet per second; USGS, U.S. Geological Survey]

\begin{tabular}{|c|c|c|c|}
\hline \multirow{2}{*}{ Site } & \multicolumn{3}{|c|}{ Base flow, in $\mathrm{ft}^{3} / \mathrm{s}$} \\
\hline & Simulated & Observed & Difference \\
\hline \multicolumn{4}{|c|}{ July 28, 2007} \\
\hline Well 3 upstream & 5.69 & 5.71 & 0.02 \\
\hline Well 3 downstream & 5.66 & 5.66 & -0.00 \\
\hline Well 7 upstream & 5.31 & 4.65 & -0.66 \\
\hline Well 7 downstream & 5.20 & 4.70 & -0.50 \\
\hline Berkshire streamgage $^{1}$ & 5.66 & 5.60 & -0.06 \\
\hline Sandy Hook streamgage ${ }^{2}$ & 8.78 & 9.20 & 0.42 \\
\hline \multicolumn{4}{|c|}{ August 3, 2007} \\
\hline Well 3 upstream & 5.45 & 4.66 & -0.79 \\
\hline Well 3 downstream & 5.40 & 4.79 & -0.61 \\
\hline Well 7 upstream & 5.20 & 3.43 & -1.77 \\
\hline Well 7 downstream & 5.05 & 3.79 & -1.26 \\
\hline Berkshire streamgage $^{1}$ & 5.40 & 4.70 & -0.70 \\
\hline Sandy Hook streamgage ${ }^{2}$ & 8.50 & 6.90 & -1.60 \\
\hline
\end{tabular}

${ }^{1}$ USGS streamgage number 012035055 .

${ }^{2}$ USGS streamgage number 01203510.

\section{Simulation of Reverse Aquifer Test}

The transient model of the United Water well field used data from the reverse aquifer test conducted from September 4 to 5, 2007, at Well 2. To simulate the various stages of the aquifer test-increased pumping of Well 2, shut off, and return to regular pumping - the groundwater model had a total of 162 stress periods and covered the period August 25 through September 5, 2007. The initial steadystate stress period was followed by transient stress periods starting about 10 days before the aquifer test so that effects of any initial conditions of starting water level and continued pumping would be minimal by the time of the aquifer test. Stress periods that covered August 25 through 31 were 4 hours long, with hourly time steps; stress periods after September 1 were hourly, each with a single time step.

The simulated production well was assigned to layer 2 and the pumping rates used in the simulation were those measured before and after the 9.5-hour reverse aquifer test when the pump was turned off. The pumping rate for the initial steady-state stress period was set at $650 \mathrm{gal} / \mathrm{min}$, the average of the pumping rates recorded from August 25 to September 4,2007 . Flow in the main stem and in the North Branch of the Pootatuck River was estimated at 0.70 and $0.30 \mathrm{ft}^{3} / \mathrm{s}$, respectively, assuming a 75-percent flow duration in the Rearing and Growth bioperiod (Ahearn, 2010).

\section{Model Calibration and Hydraulic Properties}

Water levels recorded throughout the 11-day period in the three observation wells (Wells TW-2, TW-4, and TW-6, fig. 6) were used for calibration. It was not possible to record water levels in Well 2. Hydraulic conductivity of the aquifer and of the streambed and specific yield values were varied during the model calibration process. The initial water levels specified at the boundaries of the model, based on the topographic map, were not changed during the initial calibration, but were updated with values from the basin-scale model as part of the iterative model development described earlier in this report. The final calibrated value for vertical hydraulic conductivity of the streambed was $2 \mathrm{ft} / \mathrm{d}$, which was used to calculate streambed conductance.

Hydraulic conductivity values were adjusted until the simulated water levels at the individual observation wells matched the observed water levels as closely as possible. The changes were made to groups of cells that corresponded to different geologic materials as denoted on the surficial materials map (fig. 4). There were two hydraulic conductivity zones in layers 1 and 2 and one in layer 3 (fig. 32, table 12). Calibrated value of specific yield was 0.25 in layers 1 and 2 , and specific storage was 0.00001 in all layers.

Simulated and observed water levels from the calibrated model are shown in figure 33. Visual comparison of simulated and observed water levels shows the initial water-level increase when the pump was first turned off and during the transition period into the aquifer-test nonpumping conditions match reasonably well, as do those in the transition period to pumping conditions at the end of the aquifer test. Observed and simulated water levels were compared in six ways: (A) the difference at 2 a.m. on September 5, 2007 (about halfway through the shut off portion of the aquifer test); (B) the mean absolute error and (C) median error of synchronous simulated and observed pairs of water levels during the period September 3 through September 6, 2007; (D) the mean absolute error and (E) median error of synchronous simulated and observed pairs of water levels during the period September 4, at 10 p.m. through September 5, 2007 at 8 a.m.- the part of the aquifer test when the well was shut off (table 13); and $(\mathrm{F})$ as plots of simulated residuals compared to simulated water levels and observed compared to simulated water levels (fig. 30). For the overall time period of September 3 through September 6, 2007, the mean absolute error ranged from +0.4 to $+0.5 \mathrm{ft}$ (table 13B), and the median error for the observation wells ranged from -0.2 to $-0.1 \mathrm{ft}$ (table $13 \mathrm{C}$ ). For the period September 4, at 10 p.m. through September 5, 2007 at 8 a.m., during shut off, the mean absolute error ranged from +0.9 to $+2.2 \mathrm{ft}$ (table 13D) and the median error ranged from -2.6 to $-0.8 \mathrm{ft}$ (table 13E). Figure 30 shows a good fit between simulated and observed water-level values and their residuals (see discussion earlier in this report). These differences are within the CTDEP requirements for Level A mapping (State of Connecticut, 1991). 


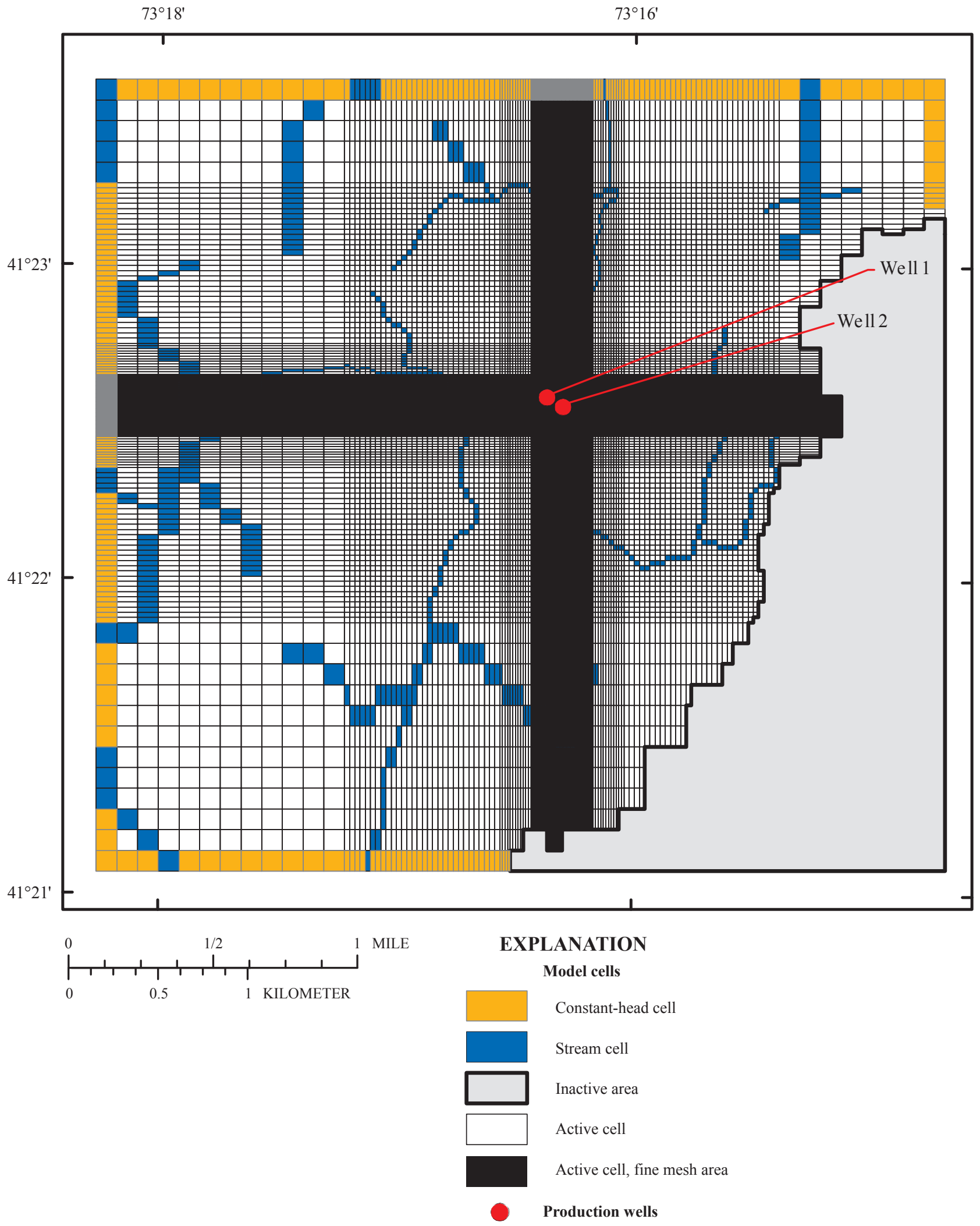

Figure 31. United Water well-field-scale model, Pootatuck River Basin, Newtown, Connecticut. 


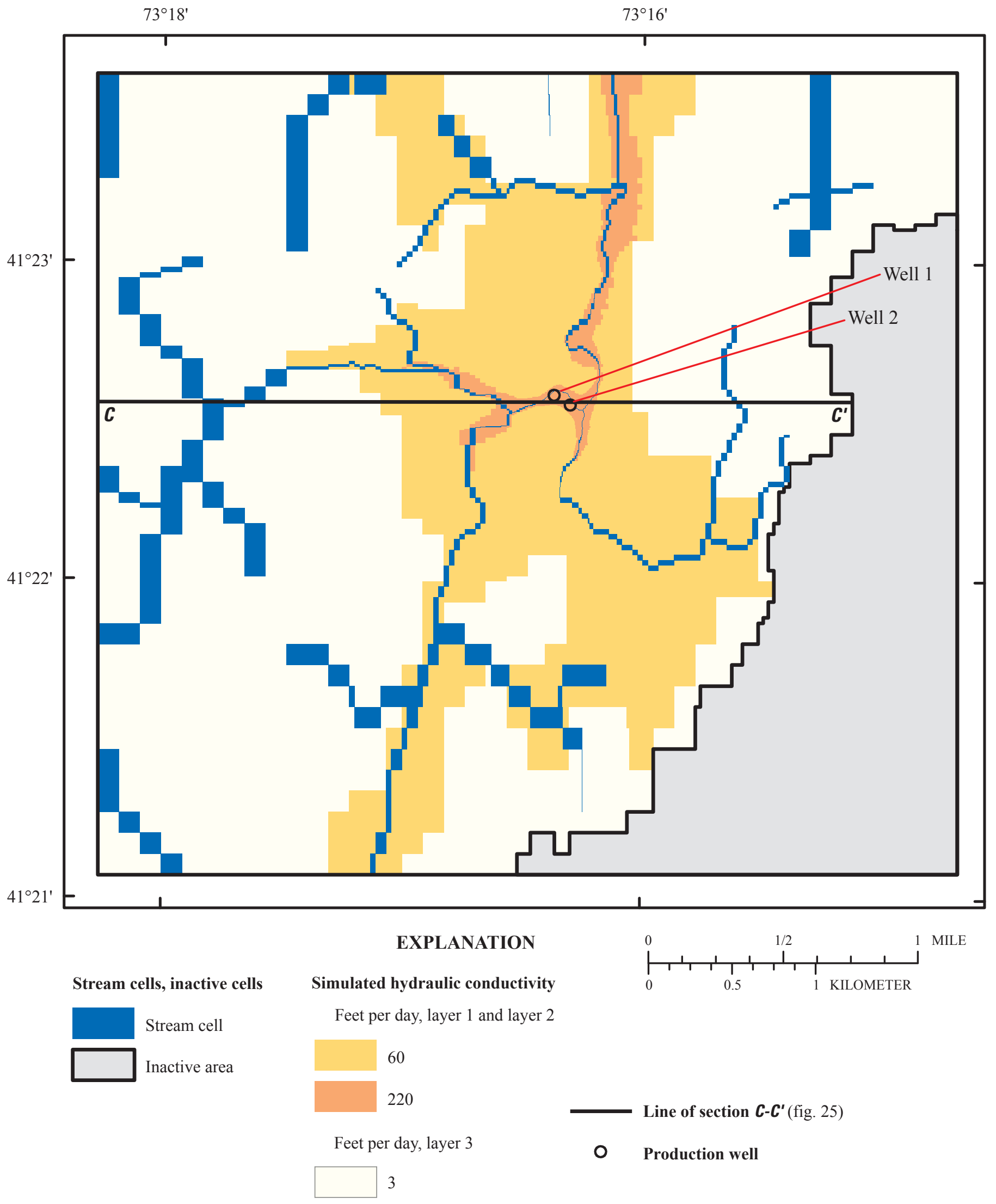

Figure 32. Hydraulic conductivity in the United Water well-field-scale model, Pootatuck River Basin, Newtown, Connecticut. 
Table 12. Calibrated hydraulic parameters of the United Water well-field-scale model, Pootatuck River Basin, Newtown, Connecticut.

$[\mathrm{ft} / \mathrm{d}$, feet per day]

\begin{tabular}{|c|c|c|c|c|c|c|}
\hline \multirow{3}{*}{ Zone } & \multicolumn{6}{|c|}{ Hydraulic conductivity (ft/d) } \\
\hline & \multicolumn{2}{|c|}{ Layer 1} & \multicolumn{2}{|c|}{ Layer 2} & \multicolumn{2}{|c|}{ Layer 3} \\
\hline & Horizontal & Vertical & Horizontal & Vertical & Horizontal & Vertical \\
\hline Valley-fill sediments near Well 2 & 60 & 6 & 60 & 6 & \multirow{2}{*}{3} & \multirow{2}{*}{3} \\
\hline Alluvium along river near Well 2 & 220 & 22 & 220 & 22 & & \\
\hline
\end{tabular}
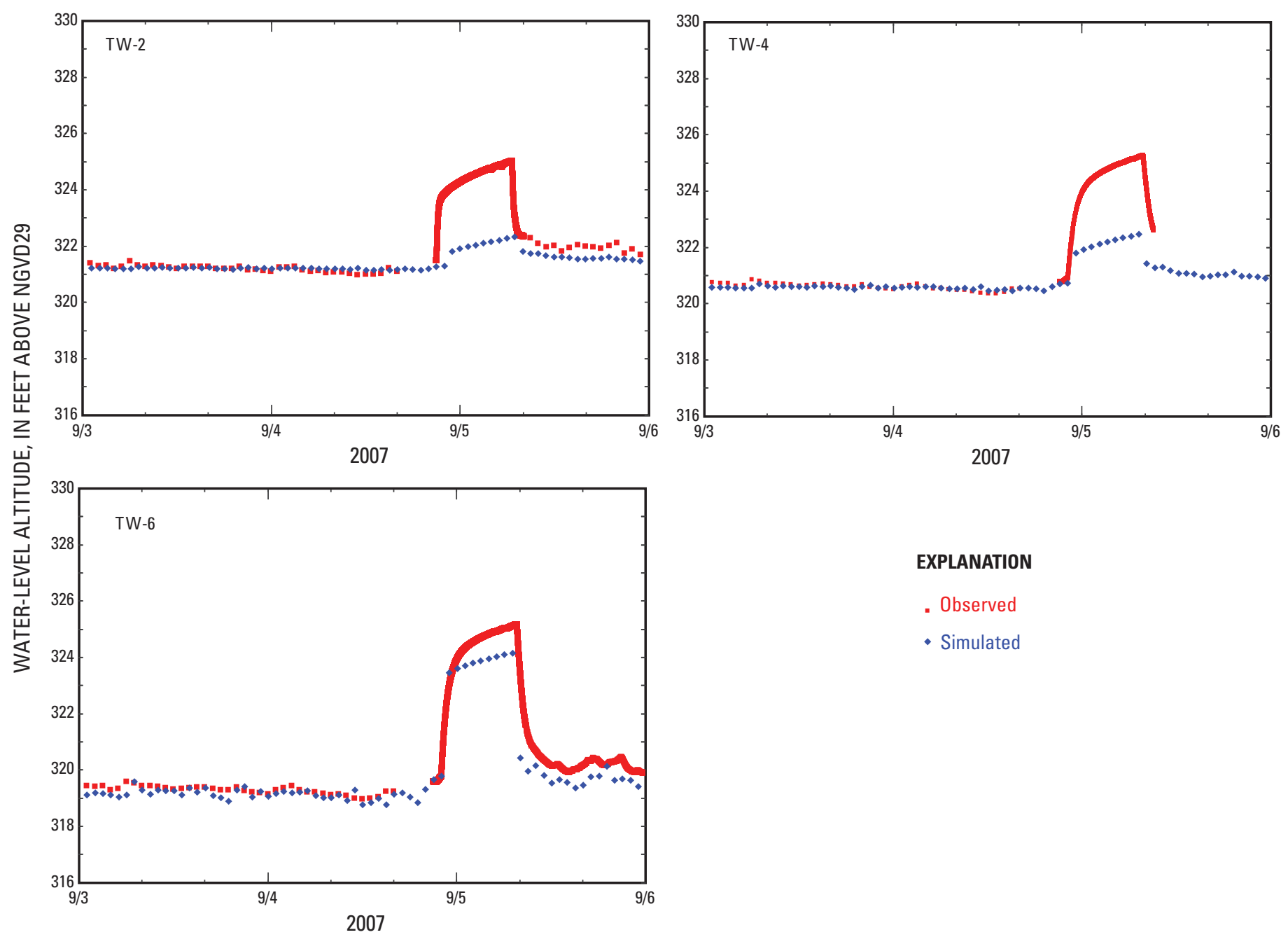

Figure 33. Simulated and observed water levels during United Water aquifer test, Pootatuck River Basin, Newtown, Connecticut. Location of wells shown in figure 6. 
Table 13. Simulated and observed water levels in wells at the United Water well field, Pootatuck River Basin, Newtown, Connecticut.

[All units in feet]

\begin{tabular}{|c|c|c|c|c|}
\hline & \multirow{2}{*}{ Date and time } & \multicolumn{3}{|c|}{ Water-level altitude } \\
\hline & & TW-2 & TW-4 & TW-6 \\
\hline Simulated & 9/05/2007 2:00 a.m. & 322.0 & 322.1 & 323.8 \\
\hline Observed & 9/05/2007 2:00 a.m. & 324.5 & 324.6 & 324.5 \\
\hline \multirow[t]{2}{*}{ A. Residual } & & -2.5 & -2.5 & -0.7 \\
\hline & \multicolumn{4}{|c|}{ September 3 through September 6, 2007} \\
\hline Number of synchronous pairs ${ }^{1}$ & & 68 & 53 & 68 \\
\hline B. Mean absolute error & & 0.5 & 0.5 & 0.4 \\
\hline \multirow[t]{2}{*}{ C. Median error } & & -0.1 & -0.1 & -0.2 \\
\hline & \multicolumn{4}{|c|}{ September 4, 10 p.m. through September 5, 8 a.m. } \\
\hline Number of synchronous pairs ${ }^{1}$ & & 11 & 11 & 11 \\
\hline D. Mean absolute error & & 2.2 & 2.2 & 0.9 \\
\hline E. Median error & & -2.5 & -2.6 & -0.8 \\
\hline
\end{tabular}

${ }^{1}$ Synchronous pairs: simulated and observed water levels with the same date and time used to calculate mean absolute error and median error for a specified period.

No direct model calibration to streamflow was possible in the United Water model because no streamgages were located within the United Water modeled area, and there were no streamflow measurements made during the reverse aquifer test. The simulated flows appear reasonable; simulated flows were 1.51 and $0.62 \mathrm{ft}^{3} / \mathrm{s}$ at the upstream and downstream measuring sites, respectively. The piezometer data, discussed earlier, showed a substantial downward gradient between the surface water and the groundwater (fig. 19), which corroborates the simulated loss of streamflow near the production well.

\section{Limitations of Well-Field-Scale Models}

The Fairfield Hills and United Water well-field-scale models were calibrated to a limited set of field data and to a short time period. Field conditions precluded accurate streamflow measurements in the vicinity of the production wells and streamflow into each model area was estimated. In addition, there was a small number of data points to use for calibration of water levels, especially for the United Water model. For the transient models, the initial steady-state stress period was calibrated to water levels measured before the aquifer tests that did not represent long-term average conditions, both because the field conditions were much drier than average and, in the United Water model, the water levels in the aquifer had not recovered to a static level. In the steady-state models, water levels at the boundaries were based on those simulated in the basin-scale model and not on actual field conditions.
The transient and steady-state models simulated all water withdrawn by the production wells as removed from the system. However, during the aquifer tests, some, if not all from the water was returned to the Pootatuck River downstream from the well fields. In addition, some of the water delivered to residents in Newtown is returned to the groundwater through septic systems.

\section{Basin-Scale Model}

The total active modeled area of the Pootatuck River basin-scale model was about $26 \mathrm{mi}^{2}$ (fig. 24). The finitedifference grid representing this area consisted of 111 rows and 81 columns of uniformly spaced model cells that were $400 \mathrm{ft}$ on a side. This cell size represented the hydrogeologic features of the Pootatuck River Basin as accurately as possible while balancing the size of the numerical model in terms of the complexity of data storage and computer solution time. The Pootatuck River Basin was subdivided vertically into three layers of variable thickness that extended from the water table into the bedrock using the same procedure as for the well-field-scale models.

\section{Layer Distribution}

The three model layers represented the primary hydrogeologic units based on the surficial materials map (fig. 4) and bedrock surface map (fig. 3). Cross-section A-A' 
(fig. 25) shows the modeled layers (cross-section location shown on fig. 24). As with the well-field-scale models, the spatial extent of the active cells in layers 1 and 2 were identical and coincide with the extent of the stratified glacial deposits that consist of areas of differing proportions of sand and gravel in the center of the valley (fig. 4). Two layers were used in order to locate the production wells in the lower part of the aquifer and to differentiate minor differences in hydraulic conductivity (fig. 34). Layer 3 represents (1) bedrock underlying the stratified glacial deposits and (2) the combined till and bedrock areas of the uplands; the active area of layer 3 was larger than the active area of layers 1 and 2 and is the entire watershed area shown in figure 34. Layers 1 and 2 were specified as convertible between confined and unconfined groundwater-flow conditions and layer 3 was specified as a confined layer.

The top of the model in the area of stratified glacial deposits was specified as land surface, derived from digital elevation data of 10-ft contour lines (Scott Sharlow, Newtown, written commun., 2007). Total thickness of the stratified glacial deposits in layers 1 and 2 ranged from 15 to $133 \mathrm{ft}$ with a median value of $30 \mathrm{ft}$. The thickness of layer 1 ranged from 7.5 to $23 \mathrm{ft}$ and the thickness of layer 2 ranged from 7.5 to $110 \mathrm{ft}$. The bottom of layer 2 represented the bedrock surface. During model calibration, a thickness of $80 \mathrm{ft}$ for layer 3 was found to be a reasonable value for most model cells. However, in the upland areas where layer 3 was the uppermost active layer, the thickness of layer 3 was increased in approximately 40 percent of the active model cells to smooth out the lower surface and avoid numerical instabilities in the model. The thickness of layer 3 in areas representing till and bedrock ranged from 80 to $413 \mathrm{ft}$.

\section{Hydrologic Boundaries}

The bedrock was modeled explicitly because it was assumed that water flows across the boundary between the upper part of bedrock and the surficial materials, especially beneath the upland areas where thin till deposits overlie bedrock. The lateral boundaries of the model, set at the basin boundary of the Pootatuck River Basin, were assumed to be no-flow boundaries. The stream reaches in the model consisted of 681 model cells grouped into 117 stream segments (fig. 24). In the area of stratified glacial deposits, the stream cells were assigned to layer 1, and in the upland bedrock and till areas the stream cells were assigned to layer 3 .

\section{Hydrologic Stresses}

There were two hydrologic stresses simulated in the basin-scale model. Precipitation recharged the groundwater at the water table and pumping from the production wells removed groundwater from the model.

\section{Recharge}

A map of areally-distributed recharge, similar to that used in the well-field-scale models, was developed for the basinscale model based on the surface and land-cover conditions in the basin. A description of the method is provided in the appendix. Using areally-distributed recharge was important because the basin-scale model was used to estimate changes in future recharge due to potential land-use changes.

The regression equation was used to compute a recharge estimate for each cell in the basin-scale model (fig. 35). The estimated recharge averaged $16 \mathrm{in} / \mathrm{yr}$ for the entire basin with a maximum of $28 \mathrm{in} / \mathrm{yr}$ for grid cells composed entirely of coarse stratified glacial deposits. These values are reasonable because average annual precipitation is about $48 \mathrm{in} / \mathrm{yr}$ (Miller and others, 2002). The recharge estimates were constrained by setting the minimum possible value to $1 \mathrm{in} / \mathrm{yr}$ to prevent unrealistic negative values. Initially, the high end value was constrained to $24 \mathrm{in} / \mathrm{yr}$ based on previous estimates of recharge in coarse stratified glacial deposits in western Connecticut (Mazzaferro, 1986). However, recent work done in the nearby Pomperaug Basin (Bjerklie and others, in press) suggests the recharge used by Mazzaferro (1986) underestimated base-flow percentages. Thus, the high-end constraint was removed to provide the best simulation results in the basin-scale model.

\section{Pumping}

Production wells were assigned to layer 2 and the simulated pumping rates were those registered for each well. Although only Wells 2, 3, and 7 were pumped during the aquifer tests conducted for this study, in order to simulate the maximum possible effect of pumping, all the wells were included in the basin-scale model. Therefore, Well 1 in the United Water well field, which is used in periods of high demand, and Well 8 in the Fairfield Hills well field, which is a backup well (and never pumped at the same time as Well 7), also were simulated in the basin-scale steady-state model. The total pumping simulated in the model was about $3.41 \mathrm{Mgal} / \mathrm{d}$, which is the sum of the registered rates for the production wells shown in table 14 .

\section{Hydraulic Properties}

The values and distribution of horizontal and vertical hydraulic conductivity for different geologic deposits were determined from the calibrated well-field-scale models. These values were applied to areas of similar deposits generalized from the surficial materials map (fig. 4). The values of hydraulic conductivity for most of the area ranged from 3 to $220 \mathrm{ft} / \mathrm{d}$ (fig. 34); the value for all of layer 3-both beneath the stratified glacial deposits and in the upland till and bedrock areaswas $3 \mathrm{ft} / \mathrm{d}$. It was assumed that wetlands in the upland areas functioned as open water bodies with less resistance to flow than the surrounding aquifer; therefore, they were assigned a horizontal and vertical hydraulic conductivity of 5,000 ft/d. 


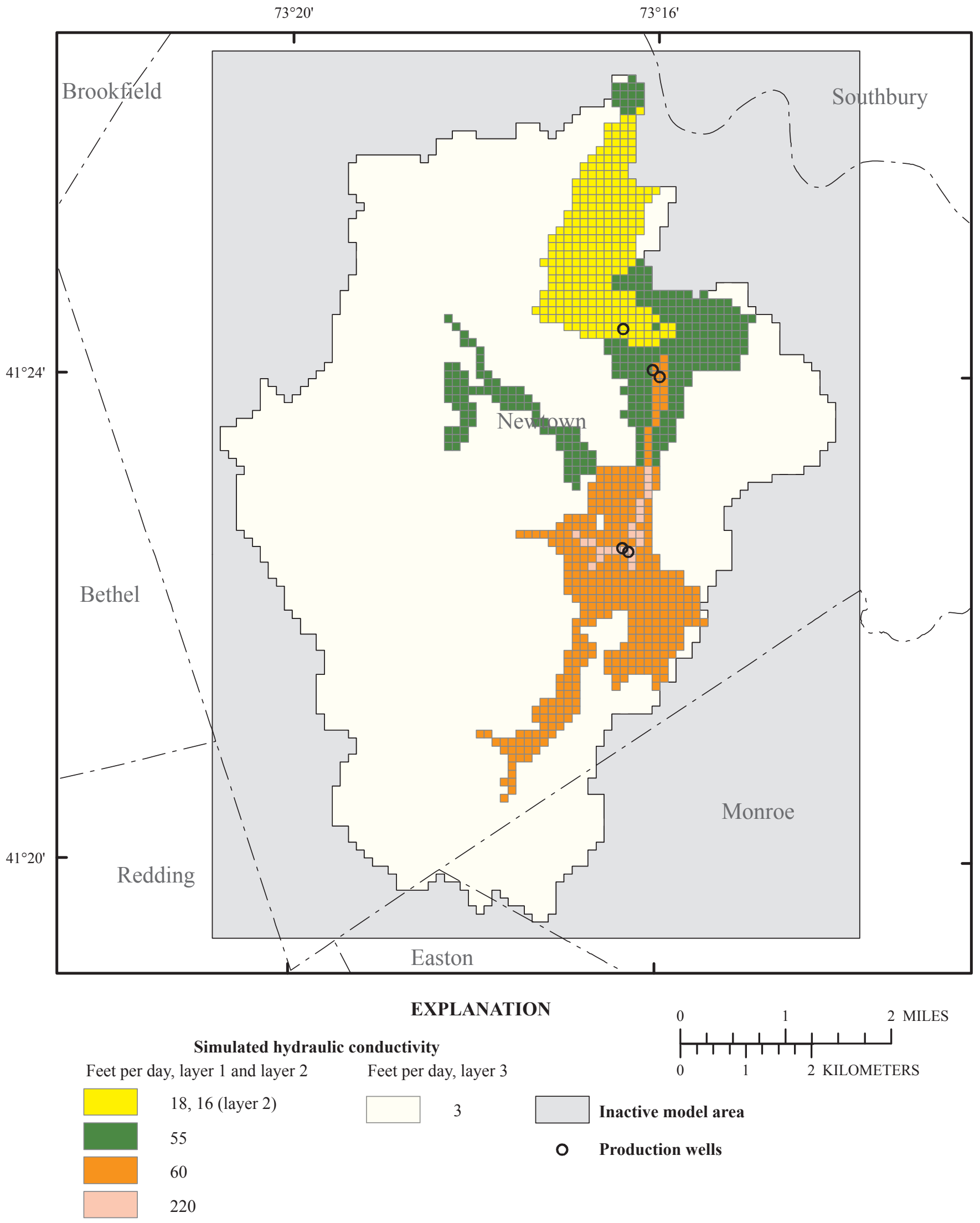

Figure 34. Simulated hydraulic conductivity of the basin-scale model, Pootatuck River Basin, Newtown, Connecticut. 


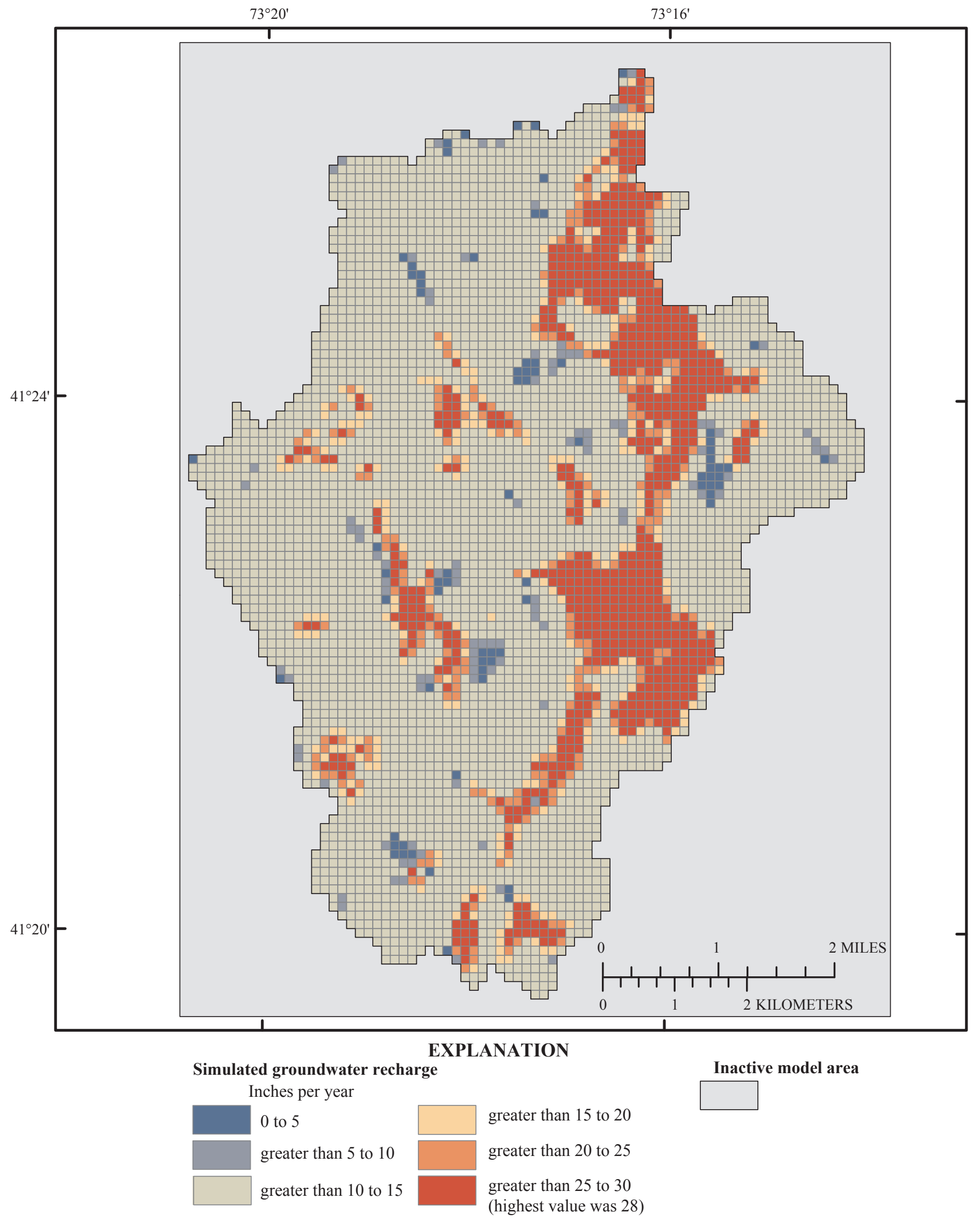

Figure 35. Areal distribution of recharge used in the basin-scale groundwater-flow model, Pootatuck River Basin, Newtown, Connecticut. 
Table 14. Registered pumping rates and distance from stream for all production wells in the basin-scale model, Pootatuck River Basin, Newtown, Connecticut.

[Registered pumping rate, maximum permissible pumping rate registered with the Connecticut Department of Environmental Protection; $\mathrm{ft}^{3} / \mathrm{d}$, cubic feet per day; Mgal/d, million gallons per day; gal/min, gallons per minute; $<$, less than]

\begin{tabular}{|c|c|c|c|c|}
\hline \multirow{2}{*}{$\begin{array}{l}\text { Production } \\
\text { well }\end{array}$} & \multicolumn{3}{|c|}{ Registered pumping rate } & \multirow{2}{*}{$\begin{array}{c}\text { Distance } \\
\text { from stream, } \\
\text { in feet }\end{array}$} \\
\hline & $\mathrm{ft}^{3} / \mathrm{d}$ & Mgal/d & $\mathrm{gal} / \mathrm{min}$ & \\
\hline Well 1 & 66,841 & 0.50 & 350 & 60 \\
\hline Well 2 & 144,376 & 1.08 & 750 & $<50$ \\
\hline Well 3 & 51,868 & 0.39 & 270 & 140 \\
\hline Well 7 & 89,967 & 0.67 & 467 & 130 \\
\hline Well 8 & 102,600 & 0.77 & 533 & $<50$ \\
\hline
\end{tabular}

\section{Basin-Scale, Steady-State Model Calibration}

Ideally, data that represent average conditions would be used to calibrate a steady-state model. In this investigation, available data included water levels measured as part of the aquifer tests, water levels of unknown quality from various other periods, and streamflow data recorded at two streamgages that include the periods of the aquifer tests. Calibration of this steady-state simulation was based mainly on estimated streamflow data at the two streamgages, and water levels measured in observation wells before the aquifer tests. Because the estimates of streamflow assumed natural, nonpumping conditions, none of the simulated wells were pumped during calibration. Hydraulic-conductivity values of the aquifer were not changed during calibration of the basinscale model; however, streambed conductance was varied.

\section{Water-Level Data}

In addition to water-level data measured in observation wells for the aquifer tests, water-level measurements made since 1967 by the USGS at a long-term observation well (NT-15) were used for model calibration. Well NT-15 is located about 2,100 ft west-northwest of Well 3 (fig. 4). The water level in Well NT-15 was $8.26 \mathrm{ft}$ below land surface on July 28, 2007, during the Fairfield Hills aquifer test and $9.38 \mathrm{ft}$ below land surface on August 28, 2007, during the United Water aquifer test. These water levels were substantially below the long-term median water level of $5.72 \mathrm{ft}$ below land surface; therefore, the simulation represents a steady-state condition that is drier than what may be expected in the area.

All the wells with reliable data are located in the valleyfill sediments and, because the model cells in the basin-scale model are $400 \mathrm{ft}$ on a side, some cells contain multiple observation wells; the five observation wells near each of the production wells in the Fairfield Hills well field were in only two model cells at each production well location. These cells were the calibration locations. The distances from observation wells to production wells ranged from 5 to $280 \mathrm{ft}$. The three observation wells in the United Water well field were located in two model cells, which were the calibration locations. These six calibration locations and Well NT-15 produced a total of seven well calibration points for the basin-scale model.

Single groundwater-level measurements were available at many domestic wells in other parts of the study area, usually measured at the time the well was drilled (fig. 1). The data from these single measurements do not necessarily represent long-term average conditions in the aquifer. Furthermore, errors in measurement-point altitudes of these wells may be more than $5 \mathrm{ft}$ in areas of high topographic relief, such as in the upland tills. Water levels in the wells in these areas were not used for model calibration but were used to assess qualitatively if the simulated water levels were reasonable.

Water levels measured in Wells 3 and 7 and in the 10 observation wells (fig. 5) immediately prior to the start of pumping at the Fairfield Hills well field were assumed to represent steady-state conditions and were used to calibrate the basin-scale model. In addition, because it was not possible to measure nonpumping water levels in the area of Well 2, the water levels measured in Wells TW-2, TW-4, and TW-6 (fig. 6) most likely do not represent steady-state conditions and may not be appropriate for comparison to simulated steadystate water levels. Using all seven calibration points, the mean of the residuals was $+1.1 \mathrm{ft}$ and the mean absolute error was $+2.0 \mathrm{ft}$, less than 2.5 percent of the total range $(78 \mathrm{ft}$ ) in water levels. Excluding the two observation points associated with Well 2 because they may not represent steady-state conditions, the mean of the residuals was $-0.5 \mathrm{ft}$, and the mean absolute error was $+0.7 \mathrm{ft}$; however, because the range was less ( $14 \mathrm{ft}$ ), this represented approximately 4.7 percent of the total range.

Figure 36 compares the simulated and observed water levels in all the wells for which data exist. The data at the seven calibration points are shown with black dots; all the residuals plot close to zero (fig. 36A), and the observed and simulated pairs plot near the 1:1 line (fig. 36B) indicating a good fit between the observed and simulated values. The many water levels from wells of uncertain altitude and location in other parts of the study area are shown with gray dots, indicating less emphasis was placed on these data. These data are more randomly distributed - some show a good fit between observed and simulated values and many others show simulated water levels below the observed value (this may indicate that some geologic feature is not represented in the model). 

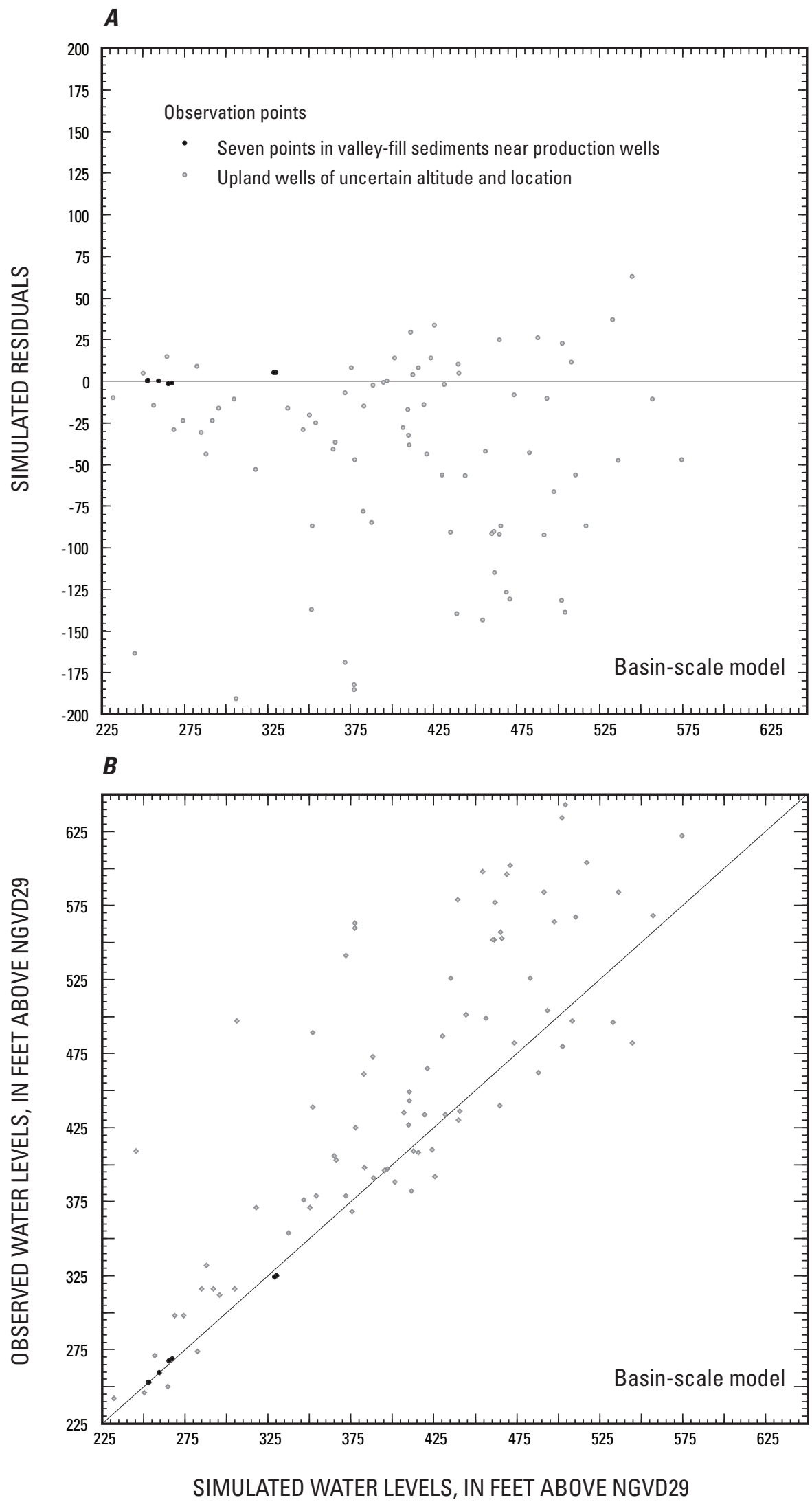

Figure 36. Comparison of simulated and observed water levels in the basin-scale model $A$, simulated residuals compared to simulated water levels and $B$, observed compared to simulated water levels, Pootatuck River Basin, Newtown, Connecticut. 


\section{Streamflow Data}

The basin-scale groundwater-flow model was run under steady-state conditions that represent long-term averages. As mentioned earlier in this report, natural (nonpumping) base flow was estimated from long-term data from the streamgage on the nearby Pomperaug River. Estimated flow data at the two streamgages on the Pootatuck River were compared to simulated flow data from the calibrated model with no wells pumping. The estimated base flow was $20.4 \mathrm{ft}^{3} / \mathrm{s}$ at Berkshire (012035055) and $28.7 \mathrm{ft}^{3} / \mathrm{s}$ at Sandy Hook (01203510). The simulated steady-state, nonpumping streamflow was 19.1 and $28.4 \mathrm{ft}^{3} / \mathrm{s}$ at Berkshire and Sandy Hook, respectively, and differed from the estimated values by 6.4 and 1.0 percent, respectively.

Simulated streamflows where four upland streams crossed onto the stratified glacial deposits were similar to estimates of mean base flow at those locations made using a technique developed by Mazzaferro and others (1979). The calibrated value for vertical hydraulic conductivity of the streambed was $2 \mathrm{ft} / \mathrm{d}$. This value falls in the range of laboratory determined vertical hydraulic conductivities of streambed samples of 1.3 to $3.9 \mathrm{ft} / \mathrm{d}$ reported by Haeni (1978).

\section{Model Limitations}

The steady-state, basin-scale groundwater-flow model of the Pootatuck River Basin has a large modeled area compared to the number and location of available calibration points. Ideally, data from calibration locations scattered throughout the modeled area, in the valley-fill sediments and till uplands, would be used for model calibration. In addition, very few data were available that represented steady-state conditions. As previously mentioned, median streamflow had to be estimated from the data in the nearby Pomperaug River Basin, and water levels measured just before pumping began in the aquifer tests were assumed to represent steady-state even though they were substantially lower than long-term average conditions. The model simulated all groundwater withdrawn by the production wells as removed from the system; however, as with the well-field-scale models, some of the water delivered to the residents of Newtown is returned to the groundwater through septic systems.

The basin-scale groundwater-flow model of the Pootatuck River Basin was calibrated to only seven well locations and two streamgage locations and estimates of base flow. Model calibration comparisons show a good match between simulated and observed steady-state water levels in the vicinity of the production wells during the periods of the aquifer tests, but the simulated water levels in the till uplands cannot be verified. Because of the size of each model cell and the distances between wells and the Pootatuck River, each simulated production well occurs within the same cell location as a stream reach, although the stream is simulated in layer 1 and the well in layer 2. This may cause the simulated contribution of stream water to the well to be greater than it actually is.

\section{Sensitivity Analysis of Groundwater-Flow Models}

A sensitivity analysis was conducted to determine how the results of the basin-scale and well-field-scale models may change if the parameters of streambed conductance, aquifer hydraulic conductivity, and recharge to the water table are altered. The values of streambed conductance were increased and decreased by a factor of 5 , and most of the other parameters were changed by 50 percent; however, hydraulic conductivity was decreased by 30 percent for the well-field-scale models because those models would not solve with a larger decrease in hydraulic conductivity. The results of each sensitivity analysis were compared to those of the calibrated model.

\section{Streambed Conductance}

The values for streambed conductance in the calibrated steady-state basin-scale and well-field-scale models were based on a vertical hydraulic conductivity of the streambed of $2 \mathrm{ft} / \mathrm{d}$. Streambed conductance in the basin-scale model ranged from 4,000 to $32,000 \mathrm{ft}^{2} / \mathrm{d}$, depending on stream order and in the well-field-scale models ranged from 100 to $32,000 \mathrm{ft}^{2} / \mathrm{d}$, depending on stream order and cell size.

To check the sensitivity of models to changes in streambed conductance, the values were increased and decreased by a factor of 5 . The large range of values affected the performance of the numerical model; the closure criteria specified in the MODFLOW solver had to be increased for the simulation to solve, and the budget error ranged from 0 to -0.64 percent. In the Fairfield Hills well-field-scale model, a different MODFLOW solver was used. Also, the simulated water level in the cell containing Well 1 was below the bottom of the cell; the simulated well "went dry" in the basin-scale model, most likely because the recharge area for Well 2, with a pumping rate much larger than Well 1 , now included the location of Well 1.

\section{Hydraulic Conductivity}

To determine the sensitivity of the models to changes in aquifer properties, all horizontal and vertical hydraulic conductivity values were increased by 50 percent from the calibrated values. In the basin-scale model, the horizontal and vertical hydraulic conductivity values were decreased by 50 percent and, as mentioned above, in the well-field-scale models, horizontal and vertical hydraulic conductivity values were decreased by 30 percent. When horizontal and vertical hydraulic conductivity values were decreased by 50 percent in the basin-scale model, the closure criteria specified in the MODFLOW solver had to be increased in order for the simulation to solve (budget error was 0.06 percent instead of -0.01 percent in the calibrated solution), thus increasing the model error and decreasing the reliability of the model results. In the well-field-scale models when hydraulic 
conductivity was decreased by 30 percent Well 3 went dry. The MODLFOW solver used the same values as in the calibrated simulation and the budget error was -0.01 percent for the Fairfield Hills model and -0.3 percent for the United Water model.

\section{Recharge}

Steady-state recharge rates to the aquifer were increased and decreased by 50 percent from the calibrated rates. Groundwater-recharge values, estimated from 1960 to 2008 as part of a regional model, ranged from an increase of 40 percent to a decrease of 40 percent from the long-term average (David Bjerklie, U.S. Geological Survey, written commun., 2010); therefore, this range of values assumes a somewhat more extreme range is possible. When recharge rates were increased by 50 percent in the basin-scale model, the closure criteria specified in the MODFLOW solver had to be increased in order for the simulation to solve-increasing the model error; however, the budget error was -0.01 percent, the same as in the calibrated solution. In the well-field-scale models, the MODFLOW solver values were unchanged from those in the calibrated solution.

\section{Delineation of Areas Contributing Recharge to Production Wells}

Groundwater-model simulations of the Pootatuck River Basin show that the source of water pumped from each production well is a combination of water that recharged the groundwater in the contributing area and water from stream inflow. The calibrated well-field-scale groundwater-flow models were used to determine the drawdown in water levels caused by the five simulated production wells in Newtown under steady-state conditions and to define the areas contributing recharge to those wells. The size and shape of the drawdown areas and the simulated areas contributing recharge are controlled by the hydraulic properties of the aquifer, the boundary conditions of the flow system, and the changes in aquifer stresses such as pumping and recharge rates. Analytical methods can be used to delineate the areas contributing recharge to production wells for simple flow conditions; however, accurate delineation of areas contributing recharge to production wells in systems affected by nearby streams and spatially variable recharge rates, such as in the Pootatuck River Basin, is facilitated by the use of a numerical model with particle tracking.

\section{Simulated Groundwater Levels and Drawdown}

The calibrated well-field-scale models simulated the steady-state groundwater system with all five production wells pumping. In addition, the well-field-scale models were used to define the nonpumping water table. In each modeled cell, the drawdown caused by the simulated production wells was calculated as the difference between the nonpumping and the pumping water levels from the steady-state simulations (fig. 37). The drawdown occurred only near the simulated production wells. The greatest drawdown was about $9 \mathrm{ft}$ for the Fairfield Hills model and about $5 \mathrm{ft}$ for the United Water model. As can be observed in figure 37, the largest areas of drawdown were near Wells 7 and 8. Pumping affects the water levels near the wells, but the groundwater does not necessarily flow to the production well (Reilly and Pollock, 1993; and Franke and others, 1998). Thus, the areas of drawdown cannot be assumed to be the same as the recharge areas discussed in the following section.

\section{Delineation of Groundwater-Recharge Areas}

Land-use decisions can affect the water quantity and quality of an aquifer and thus affect of the water pumped for public supply. Local planners need information on the source of the groundwater to wells in order to make wise land-use decisions. In addition, protection of water quality in production wells is a major concern of the CTDEP, and the Level A mapping regulations require delineation of areas contributing recharge to wells under the maximum stress possible (State of Connecticut, 1991). To simulate the maximum extent of recharge areas to production wells, the well-field-scale models were run with all potential wells pumping at their registered (maximum allowable) rates, even though this is not the normal operation of the Fairfield Hills or United Water systems.

In the well-field-scale models, the USGS particletracking program MODPATH (Pollock, 1994) was used in conjunction with MODFLOW (Harbaugh and others, 2000) to determine the areas contributing recharge to production wells in the Pootatuck River Basin. In the particle-tracking analysis, the top face of each active model cell at the water table was "seeded" with 16 particles in a $4 \times 4$ array. These particles were tracked forward through the simulated flow system until they reached the production wells. The recharge area to a well was the starting location of the particles captured by that well.

The Fairfield Hills well-field-scale model simulated pumping from Wells 3, 7, and 8. However, when simulated pumping in Well 3 was greater than $25,000 \mathrm{ft}^{3} / \mathrm{d}(0.19 \mathrm{Mgal} / \mathrm{d})$, the simulated water level in the well cell dropped below the bottom of the cell - it went dry; therefore, only Wells 7 and 8 were pumped at their registered rates, 0.67 and $0.77 \mathrm{Mgal} / \mathrm{d}$, respectively. Even though simulated pumping in Well 3 was less than the registered rate $(0.39 \mathrm{Mgal} / \mathrm{d})$, it was higher than the maximum rate that could be maintained during the aquifer test $(0.16 \mathrm{Mgal} / \mathrm{d})$. However, the inability of the model to simulate the maximum pumping rate of Well 3 is an additional limitation of the model and could indicate that an unknown geologic feature is not included in the groundwater model. The United Water well-field-scale model was run with 


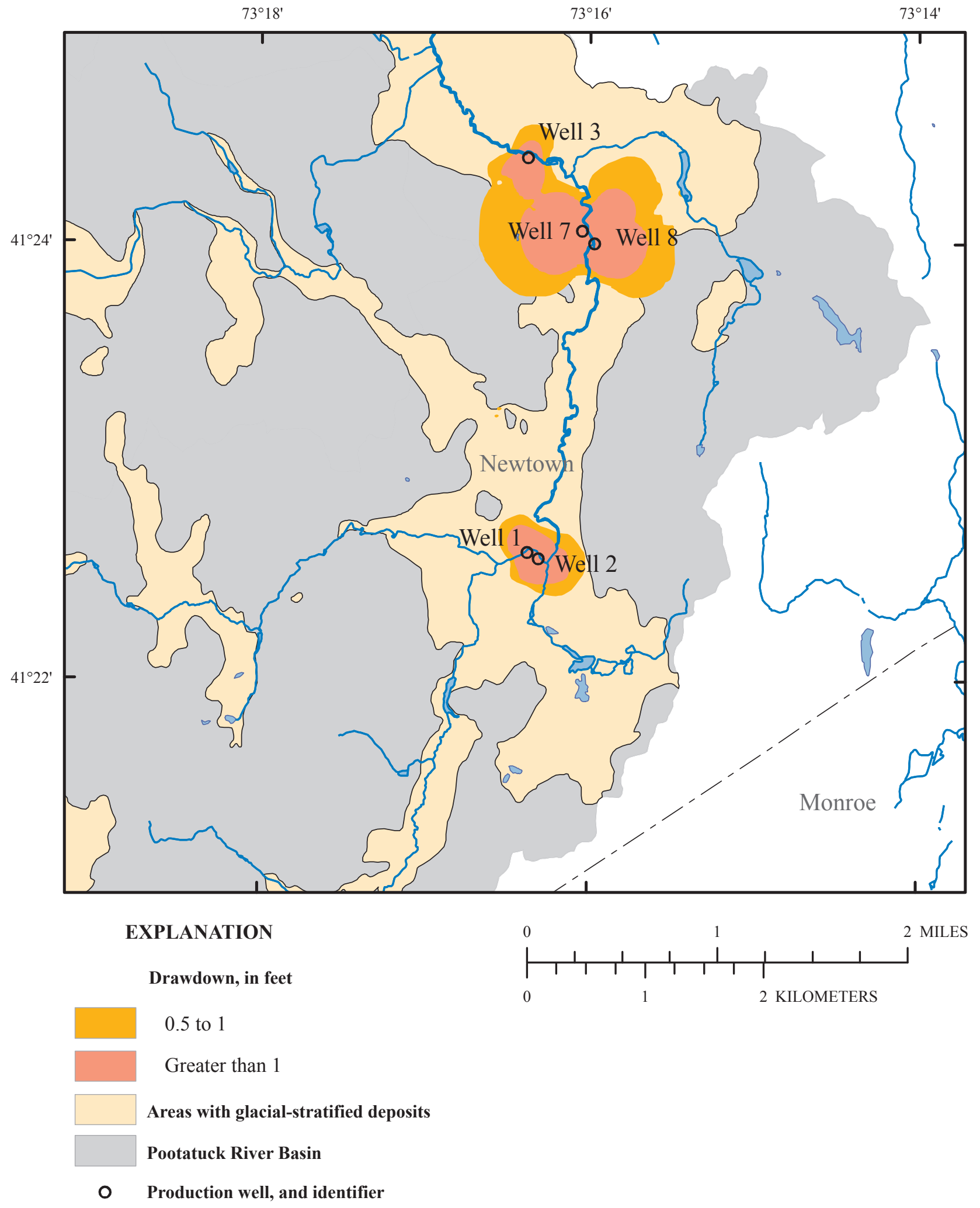

Figure 37. Drawdown caused by simulated production wells in the Pootatuck River Basin, Newtown, Connecticut. 
Wells 1 and 2 pumping at their registered rates, 0.50 and $1.08 \mathrm{Mgal} / \mathrm{d}$, respectively.

Areas contributing recharge for conditions represented by the calibrated well-field-scale, steady-state groundwater-flow models of the Pootatuck River Basin are shown in figure 38. The area contributing recharge in the Fairfield Hills model (northern box on figure 38) included narrow parts of the aquifer that extended beyond the immediate upgradient areas, probably because of deeper groundwater-flow paths. The ends of these "tails" are close to the boundary at the southwestern corner of the model. However, this is a very small part of the recharge area with little flow from the boundary.

As mentioned previously, the groundwater-flow models described in this report include the upland till areas; therefore, parts of the recharge areas shown in figure 38 are in the uplands. Because data from this study will be used to fulfill the Level A mapping regulations, a second figure is provided to be consistent with the guidelines for that program (State of Connecticut, 1991). Figure 39 shows the areas contributing recharge in the stratified glacial deposits and the upland area from which surface water would flow to those areas.

Recharge to each model cell varied depending on the physical and land-use conditions at that location. Water coming from the recharge area to each well in the well-fieldscale models was determined using a Geographic Information System processing technique to assign the cell-specific recharge rate to each cell or portion of a cell in the total recharge area. (Each of the 16 particles in each cell occupied a portion of the cell area, and in some cells not all of the particles tracked to the production well.) That recharge rate was then multiplied by the corresponding area to determine the volume of water originating in each cell; the volumes were then summed for all the cells that comprise the area contributing recharge for each production well. Because of the numerical problem with simulation of Well 3, results from that well are shown in the table but are not included in the following discussion.

The volume of water pumped from each well derived from only the area contributing recharge ranged from 20 to 62 percent (table 15); because areal recharge and stream inflow are the only sources of water to the wells in this model, the volume from stream inflow ranged from 38 to 80 percent. These results show that stream inflow to the groundwater system can be a substantial part of the water from a production well in the Pootatuck River Basin. Many production wells near streams induce stream inflow and production, wells are often sited near streams to capture this source of water.

\section{Sensitivity Analysis of Groundwater Recharge Areas}

The recharge areas resulting from each sensitivity analysis were compared to those of the calibrated model in each of the two well-field-scale models. Table 16, Parts A through
Table 15. Source of water to production wells, Pootatuck River Basin, Newtown, Connecticut.

[ns, not simulated; italics, results for Well 3 presented in table but are not discussed]

\begin{tabular}{|c|c|c|c|c|c|}
\hline \multirow{3}{*}{ Source } & \multicolumn{5}{|c|}{$\begin{array}{l}\text { Percent of volume pumped from each well } \\
\text { derived from stream inflow and from the } \\
\text { contributing area }\end{array}$} \\
\hline & Well 1 & Well 2 & Well $3^{1}$ & Well 7 & Well 8 \\
\hline & \multicolumn{5}{|c|}{ Calibrated result for well-field-scale models } \\
\hline Stream inflow & 80 & 38 & $n s$ & 49 & 46 \\
\hline Recharge area & 20 & 62 & 100 & 51 & 54 \\
\hline Total & 100 & 100 & 100 & 100 & 100 \\
\hline
\end{tabular}

${ }^{1}$ Pumping rate at Well 3 set to 25,000 cubic feet per day. Well 3 went dry above that rate, perhaps because of an unknown geologic feature not simulated in the groundwater model.

$\mathrm{C}$, shows the size of the contributing area and the amount of recharge from the contributing area as well as the percent change from the calibrated results. Part D shows the volume of water from the contributing area for the well-field-scale models and the percent change from the calibrated results.

\section{Streambed Conductance}

When streambed conductance was decreased by a factor of 5, less stream inflow was available to the production well and the size of the recharge areas and the volumes of water derived from the recharge areas increased. The recharge areas increased by 40 to 273 percent and the recharge volumes by 34 to 250 percent (table 16A). The results also show that the percentage of the total volume of pumped water derived from only the recharge areas increased to 69 to 83 percent (table 16D). Well 3, pumping at 25,000 $\mathrm{ft}^{3} / \mathrm{d}$ was less sensitive to a change in streambed conductance than the other wells and Well 1 was the most sensitive.

When streambed conductance was increased by a factor of 5, more water was available from stream inflow and the recharge areas and the volumes of water derived from these recharge areas decreased by 0 to 20 percent. The results show that the total volume of water to each production well derived from only the recharge area ranged from 16 to 63 percent; the remainder of the volume was derived from stream inflow (tables 16A and D). 


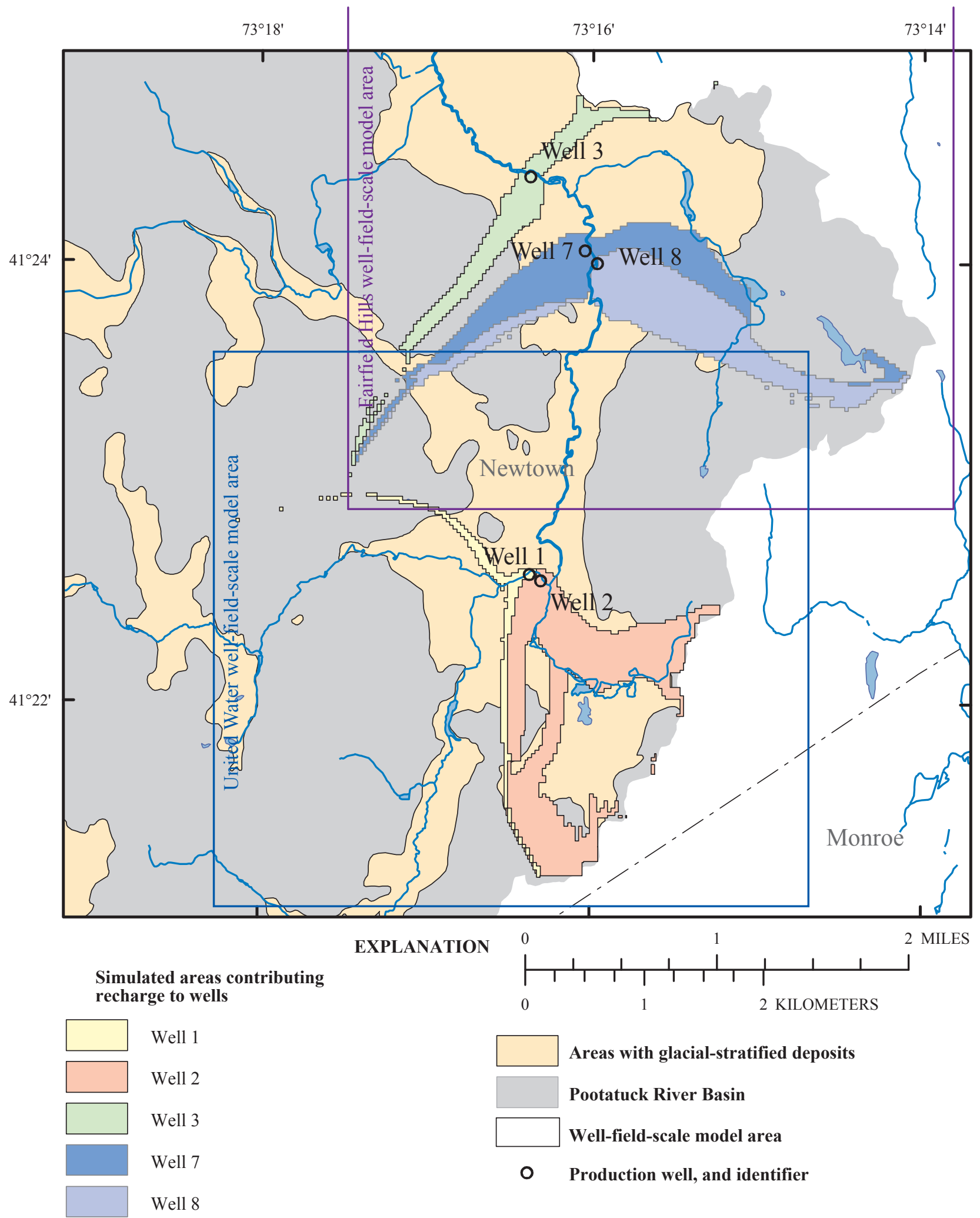

Figure 38. Simulated areas contributing recharge to production wells in the well-field-scale models, Pootatuck River Basin, Newtown, Connecticut. 


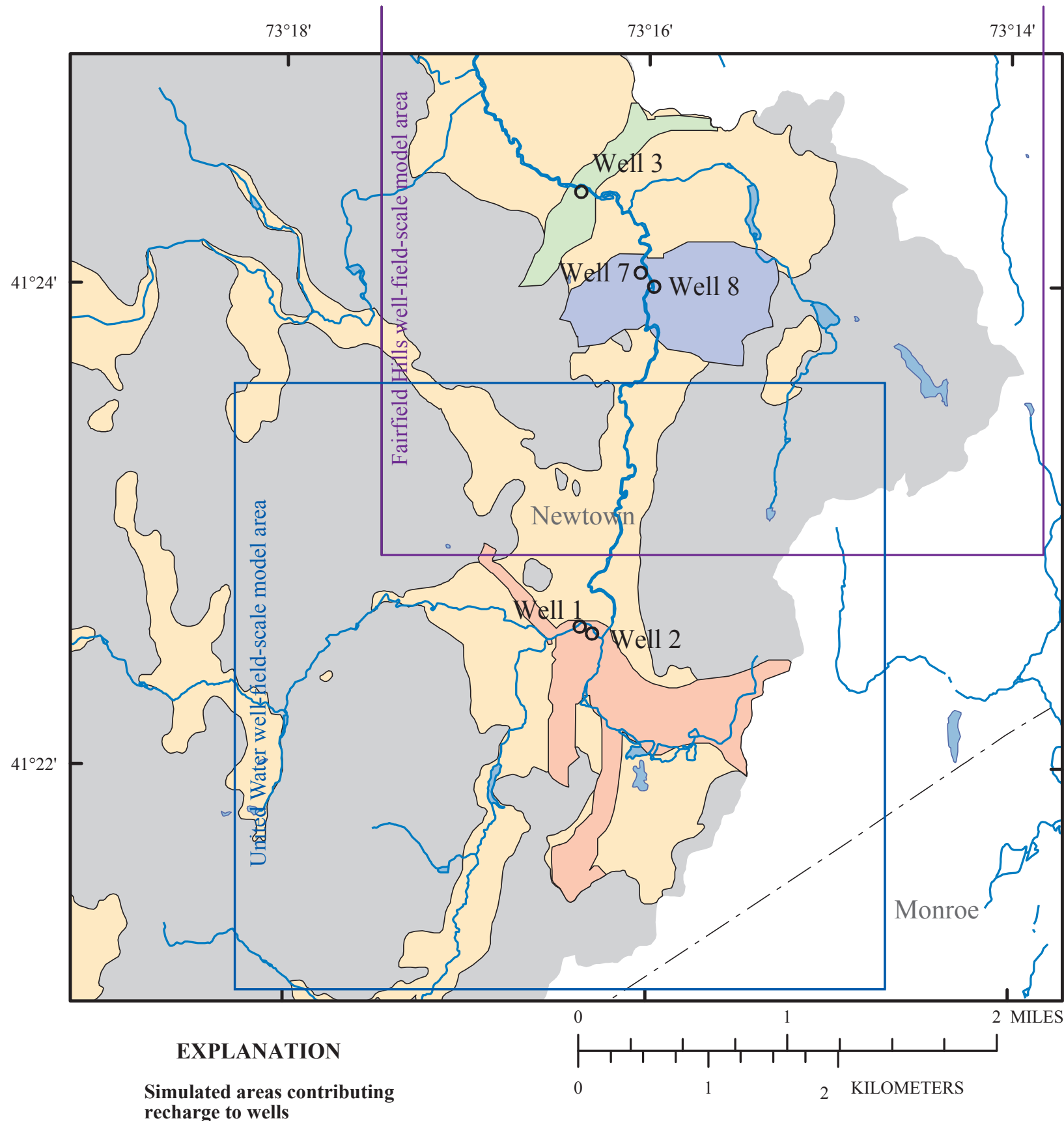
recharge to wells

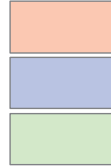

Wells 1 and 2 combined

Wells 7 and 8 combined

Well 3

Areas with glacial-stratified deposits

Pootatuck River Basin

O Production well, and identifier

Figure 39. Simulated areas contributing recharge to production wells using Level A mapping regulations in the well-field-scale models, Pootatuck River Basin, Newtown, Connecticut. 


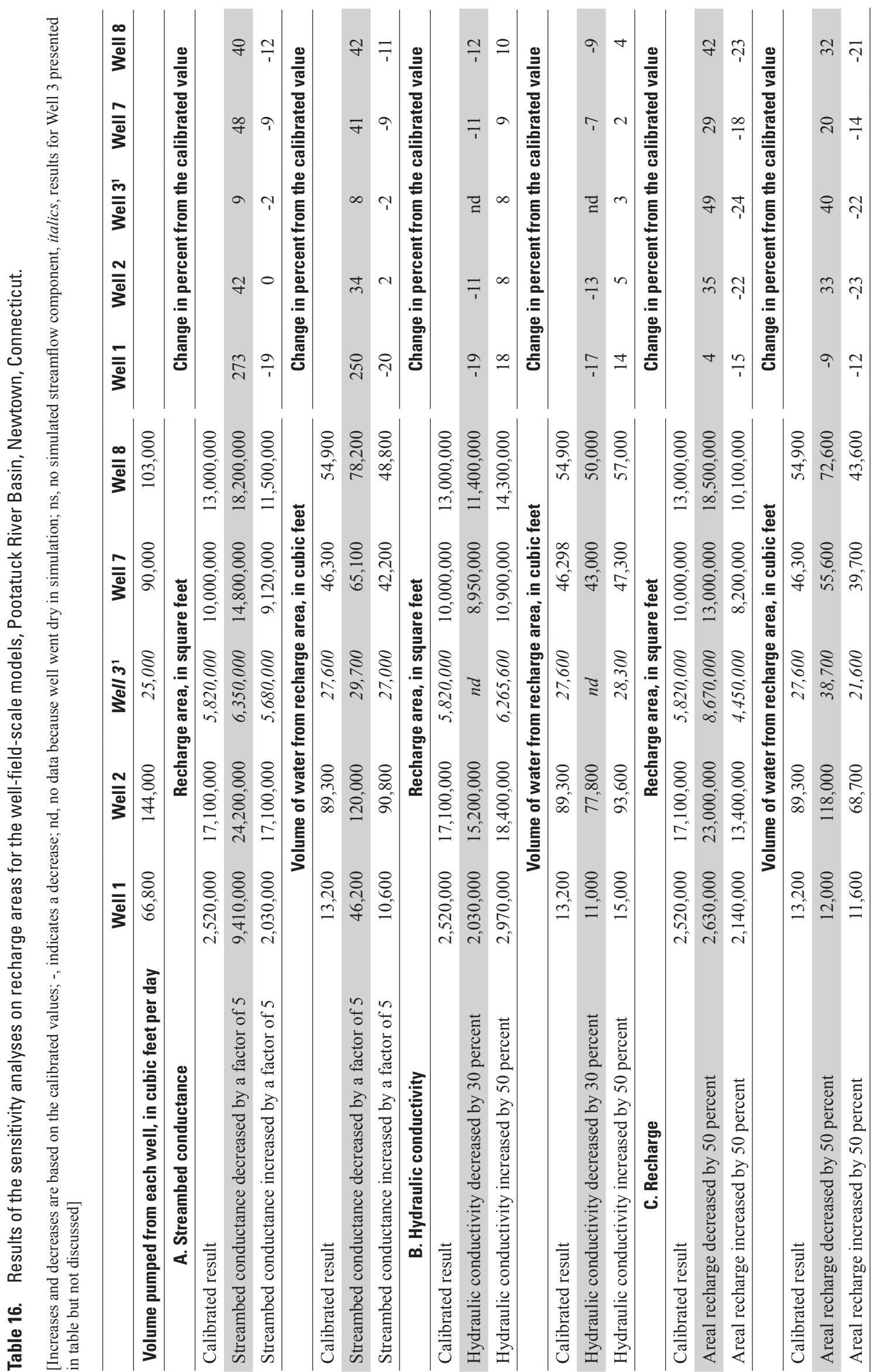


Table 16. Results of the sensitivity analyses on recharge areas for the well-field-scale models, Pootatuck River Basin, Newtown, Connecticut.-Continued

[Increases and decreases are based on the calibrated values; -, indicates a decrease; nd, no data because well went dry in simulation; ns, no simulated streamflow component, italics, results for Well 3 presented in table but not discussed]

\begin{tabular}{|c|c|c|c|c|c|}
\hline \multicolumn{6}{|c|}{ D. Percent of volume pumped from each well derived from stream inflow and from the contributing area } \\
\hline & Well 1 & Well 2 & Well $3^{1}$ & Well 7 & Well 8 \\
\hline Source & \multicolumn{5}{|c|}{ Calibrated result ${ }^{2}$} \\
\hline Stream inflow & 80 & 38 & $n s$ & 49 & 46 \\
\hline Recharge area & 20 & 62 & 100 & 51 & 54 \\
\hline \multirow[t]{2}{*}{ Total: } & 100 & 100 & 100 & 100 & 100 \\
\hline & \multicolumn{5}{|c|}{ Streambed conductance decreased by a factor of 5} \\
\hline Stream inflow & 31 & 17 & 19 & 28 & 24 \\
\hline Recharge area & 69 & 83 & 81 & 72 & 76 \\
\hline \multirow[t]{2}{*}{ Total: } & 100 & 100 & 100 & 100 & 100 \\
\hline & \multicolumn{5}{|c|}{ Streambed conductance increased by a factor of 5} \\
\hline Stream inflow & 84 & 37 & 8 & 53 & 52 \\
\hline Recharge area & 16 & 63 & 92 & 47 & 48 \\
\hline \multirow[t]{2}{*}{ Total: } & 100 & 100 & 100 & 100 & 100 \\
\hline & \multicolumn{5}{|c|}{ Hydraulic conductivity decreased by 30 percent } \\
\hline Stream inflow & 83 & 46 & nd & 52 & 51 \\
\hline Recharge area & 17 & 54 & $n d$ & 48 & 49 \\
\hline \multirow[t]{2}{*}{ Total: } & 100 & 100 & nd & 100 & 100 \\
\hline & \multicolumn{5}{|c|}{ Hydraulic conductivity increased by 50 percent } \\
\hline Stream inflow & 78 & 35 & $n s$ & 47 & 44 \\
\hline Recharge area & 22 & 65 & 100 & 53 & 56 \\
\hline \multirow[t]{2}{*}{ Total: } & 100 & 100 & 100 & 100 & 100 \\
\hline & \multicolumn{5}{|c|}{ Areal recharge decreased by 50 percent } \\
\hline Stream inflow & 82 & 18 & $n s$ & 38 & 29 \\
\hline Recharge area & 18 & 82 & 100 & 62 & 71 \\
\hline \multirow[t]{2}{*}{ Total: } & 100 & 100 & 100 & 100 & 100 \\
\hline & \multicolumn{5}{|c|}{ Areal recharge increased by 50 percent } \\
\hline Stream inflow & 83 & 52 & 14 & 56 & 58 \\
\hline Recharge area & 17 & 48 & 86 & 44 & 42 \\
\hline Total: & 100 & 100 & 100 & 100 & 100 \\
\hline
\end{tabular}

${ }^{1}$ Pumping rate at Well 3 set to 25,000 cubic feet per day. Well 3 went dry above that rate, perhaps because of an unknown geologic feature not simulated in the groundwater model.

${ }^{2}$ Data presented in table 15. 


\section{Hydraulic Conductivity}

When the horizontal and vertical hydraulic conductivity values were decreased by 30 percent, recharge areas decreased by 11 to 19 percent and the volume of water derived from these recharge areas decreased by 7 to 17 percent (table 16B). The results show that the percentage of the total volume of water to each production well derived only from the recharge area ranged from 17 to 54 percent for the well-field-scale models; the remainder of the volume was derived from stream inflow (table 16D).

When horizontal and vertical hydraulic conductivity values were increased by 50 percent from the calibrated values, the recharge areas for the production wells and the volumes derived from those recharge areas increased by 8 to 18 percent and 2 to 14 percent, respectively (table 16B). The results show that the percent of the total volume of water to each production well derived only from the recharge area ranged from 22 to 65 percent; the remainder of the volume was derived from stream inflow (table 16D). The differences in these percentages were attributed to the areally-variable recharge rate as well as the large influence of the stream on the hydrologic system as described above. The areas contributing recharge to Wells 1,3 , and 8 were sensitive to a decrease in hydraulic conductivity (Well 3 went dry in the well-field-scale model) and the area contributing recharge to Well 1 was most sensitive to an increase in hydraulic conductivity (table 16B).

\section{Recharge}

When recharge rates were decreased by 50 percent, the recharge areas that resulted were 4 to 42 percent larger and the volumes of water derived from these recharge areas ranged from 9 percent smaller to 33 percent larger (table 16C). The results show that the percent of the total volume of water to each production well derived only from the recharge area was 18 to 82 percent in the well-field-scale models; the remainder of the volume was derived from stream inflow (table 16D).

When the recharge rates were increased by 50 percent, the recharge areas that resulted decreased by 15 to 23 percent and the change in volumes of water derived from these recharge areas decreased from 12 to 23 percent (table 16C). The results show that the percentage of the total volume of water to each production well derived only from the recharge area was 17 to 48 percent in the well-field-scale models (table 16D); the remainder of the volume was derived from stream inflow. The differences in these percentages were attributed to the areally-variable recharge rate and to the influence of the stream on the hydrologic system. Wells 2 and 8 were the most sensitive to an increase and decrease in recharge.

The spatial extents of the recharge areas determined during the sensitivity analyses were stacked on top of each other to show the maximum possible extent or possible change in geographic position of simulated recharge areas. This ensures that if one of the instances described in a sensitivity simulation were to be true in the Pootatuck River Basin, the resulting recharge area has been identified - these areas would be analogous to maximum "error bars" for the recharge areas and are shown in figure 40 . The maximum extent of the simulated recharge areas intersects the boundaries of the models, particularly the contributing area to Well 3 . Therefore, the arbitrary constant-head boundary is supplying water to the pumped wells. If the model were extended, the simulated recharge area in the till and bedrock uplands would be larger than that shown on the map.

The results of the sensitivity simulations varied by production well and simulation; there was no apparent overall pattern that would indicate the calibrated values were incorrect. In terms of overall change from the calibrated model, a few results stand out:

1. The sensitivity analyses where values of the parameters were decreased showed larger changes in recharge areas than those simulations in which parameter values were increased;

2. A decrease by a factor of 5 in streambed conductivity had the greatest effect of all of the sensitivity analyses and increased the areal extent of the recharge areas, thereby decreasing the percent of pumped water derived from stream inflow and increasing the percent of water derived from the areal recharge; and

3. A decrease of 50 percent in areal recharge had the second greatest effect, also increasing the areal extent of the recharge areas.

Decreases in both streambed conductance and areal recharge decrease the amount of water available to satisfy the demand for water at the production wells.

\section{Simulation of the Interaction between Groundwater and Surface Water}

The basin-scale model was used to assess the effects of the production wells on the groundwater levels and base flow in the Pootatuck River. In addition, it was used to determine the water budget - the relative amounts of water coming from the recharge area and from stream inflow.

\section{Sensitivity Analysis of Simulated Groundwater Levels}

The basin-scale groundwater-flow model was used to define the steady-state water table with all the wells pumping. The discussion focuses on the center of the valley because all the calibration points in the model are in the stratified glacial deposits. 


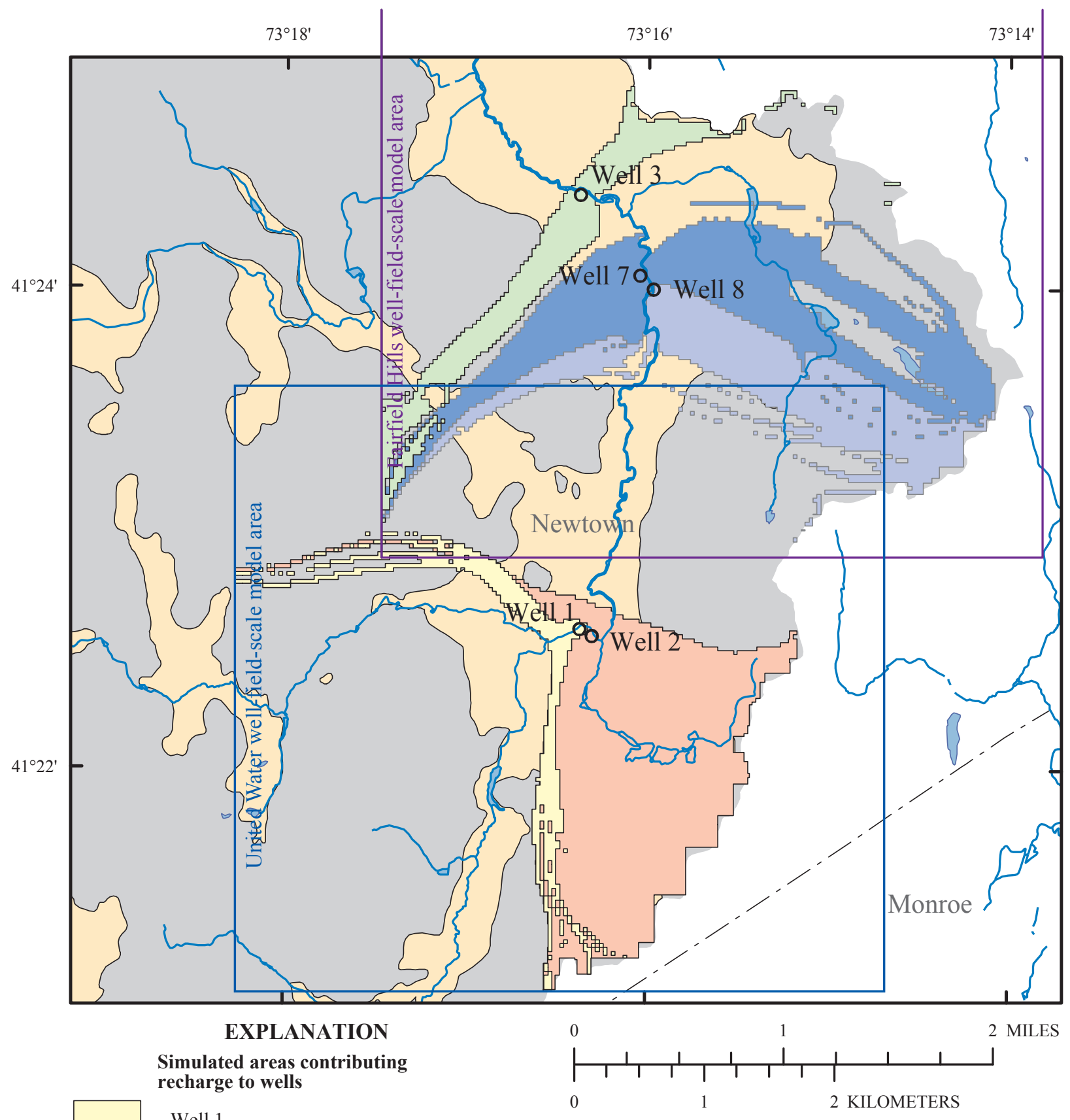

Well 1

Well 2

Well 3

Well 7

Well 8

\begin{tabular}{|l}
\hline Areas with glacial stratified deposits \\
\hline
\end{tabular}

Pootatuck River Basin

○ Production well, and identifier

Figure 40. Combination of simulated recharge areas resulting from the sensitivity simulations, Pootatuck River Basin, Newtown, Connecticut. 
The sensitivity simulations done on the basin-scale model were the same as those done on the well-field-scale models except the hydraulic conductivity was reduced by 50 percent. As discussed in the "Model Limitations" section of this report, there were only seven calibration points (cells) for groundwater levels because of the coarse discretization (cells were $400 \times 400 \mathrm{ft}$ ). Observation wells NT-85, NT-86, NT-90, and NT-91 near Well 3 were in a single cell; observation wells NT-106, NT-107, NT-108, and NT-109 near Well 7 also were in a single cell. Therefore, the average of the observed water levels in these wells was compared to the simulated water level in the observation cell. In addition, because it was not possible to measure water levels near Wells 1 and 2 in nonpumping conditions, the model may not represent steady-state conditions in this area.

The mean of the residuals for each of the sensitivity simulations at each of the calibration points is shown in table 17 . The sensitivity model with lowered recharge had the lowest mean residual, $0.05 \mathrm{ft}$, less than that in the calibrated model $(1.10 \mathrm{ft})$, but there was a greater range of values - the positive residuals balanced out the negative ones; also, one of the observation wells went dry, as might be expected because there was less water available to the groundwater system. The calibrated model had the lowest mean absolute error $(1.95 \mathrm{ft})$; the lowered recharge model was $2.33 \mathrm{ft}$. If the two calibration points near Wells 1 and 2 are excluded from the analysis, the mean of the residuals for the calibrated model was -0.49 . The sensitivity model with lowered streambed conductance had the greatest residual. The connection between the aquifer and the stream is an important component of the hydrologic system; a reduction of stream inflow near the production wells would cause water levels in the aquifer to be lower, and lower streambed conductance in other areas could prevent aquifer discharge to the stream, thereby causing higher water levels. Figure 41 shows a comparison of the groundwater levels in the calibrated model and in each of the sensitivity models. The simulated water levels near the United Water well field are consistently higher than the observed water levels; this supports the assumption that the observed water levels were affected by the production wells and did not represent steadystate conditions. Although the points on figure 41 representing calibrated model of the United Water well field do not plot near the 1:1 line, they are in the middle of the data points from the sensitivity simulations.

In several of the sensitivity simulations, some of the calibration cells went dry. One or more wells went dry in all but the calibrated model and the simulation with increased recharge; Well NT-94, the background well, went dry in four of the sensitivity simulations. The model was most sensitive to reduction in streambed conductance - the mean of the residuals was $-5.35 \mathrm{ft}$, and the mean absolute error was $+4.51 \mathrm{ft}$.

\section{Sensitivity Analysis of Stream Base Flow in the Pootatuck River}

The calibrated basin-scale model was used to simulate base flow along the main stem Pootatuck River (fig. 42). Because figure 42 shows cumulative flow, the sharp increases on the graph represent inflow from tributary streams, and the decreases represent reduction in base flow downstream from the production wells. The sensitivity of the base flow to changes in model parameters also is shown in figure 42. Changing the streambed and conductivity parameters had little effect on the base flow; the simulated base flow is not sensitive to these parameters. Changes in the recharge, however, have a substantial effect on the streamflow. Future development in the basin will increase the impervious surface area, thereby changing the amount of recharge that reaches the groundwater system and affecting the base flow in the Pootatuck River. Simulation of future scenarios is described later in this report.

\section{Simulated Water Budgets}

Simulated average annual water budgets for the nonpumping and pumping scenarios in the basin-scale-model were summarized for 26 subbasins of the Pootatuck River Basin ranging in size from less than 0.1 to $3.9 \mathrm{mi}^{2}$ (fig. 43). Geographic and hydrologic position, as well as the rate of recharge to each subbasin, determined what component of the water budget was the greatest source of water to that subbasin. For subbasins located in upland, headwater areas (subbasins 1-15 and 26), recharge from precipitation was the greatest source of water, whereas in subbasins located further downstream (subbasins 16-25), stream inflow was the greatest source of water. When comparing pumping and nonpumping conditions in the calibrated model, the steady-state simulations show that streamflows downstream from the production well are generally decreased by the amount of pumping; streamflow in subbasin 16, near the outlet of the Pootatuck River Basin, was decreased by about $5.3 \mathrm{ft}^{3} / \mathrm{s}$, the total amount of pumping in the basin. 
Table 17. Results of sensitivity analysis on water levels in the basin-scale model, Pootatuck River Basin, Newtown, Connecticut.

[Residual, difference between simulated and observed water levels]

\begin{tabular}{lcccc}
\hline \multicolumn{1}{c}{ Simulation } & $\begin{array}{c}\text { Range of residuals, } \\
\text { in feet }\end{array}$ & $\begin{array}{c}\text { Mean } \\
\text { residual, } \\
\text { in feet }\end{array}$ & $\begin{array}{c}\text { Mean } \\
\text { absolute error, } \\
\text { in feet }\end{array}$ & $\begin{array}{c}\text { Number of dry } \\
\text { well cells }\end{array}$ \\
\hline Calibrated model & -1.72 to 5.12 & 1.10 & 1.95 & 0 \\
Streambed divided by 5 & -13.82 to 1.62 & -5.35 & 4.51 & 3 \\
Streambed times 5 & -1.88 to 6.00 & 1.32 & 2.19 & 1 \\
Conductivity minus 50 percent & -4.30 to 4.10 & 1.09 & 2.01 & 2 \\
Conductivity plus 50 percent & -2.27 to 4.94 & 0.87 & 2.09 & 1 \\
Recharge minus 50 percent & -3.31 to 4.53 & 0.05 & 2.33 & 1 \\
Recharge plus 50 percent & -2.35 to 4.84 & 1.08 & 2.34 & 0 \\
\hline
\end{tabular}

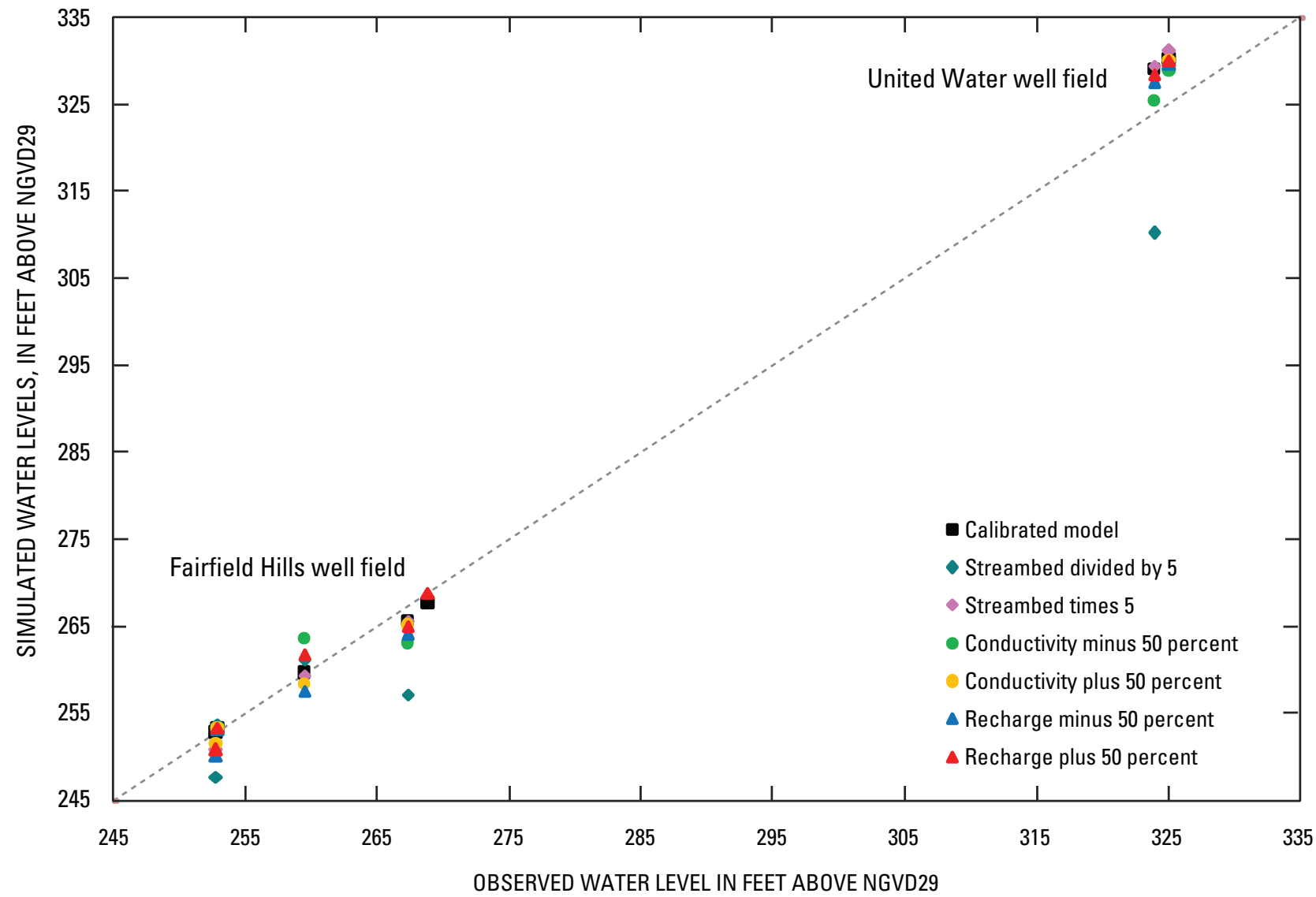

Figure 41. Comparison of simulated and observed water levels in the basin-scale model sensitivity analysis, Pootatuck River Basin, Newtown, Connecticut. 


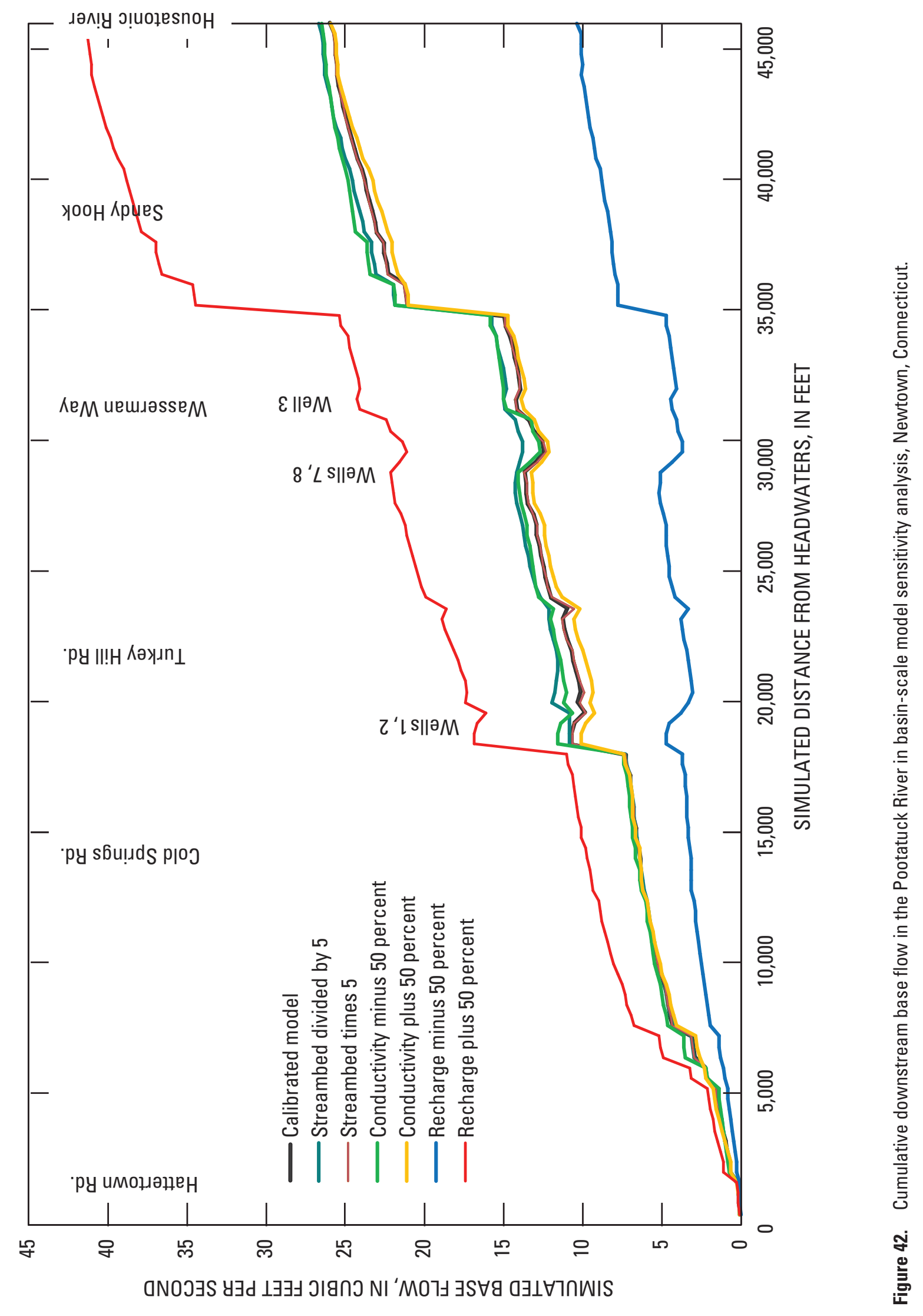




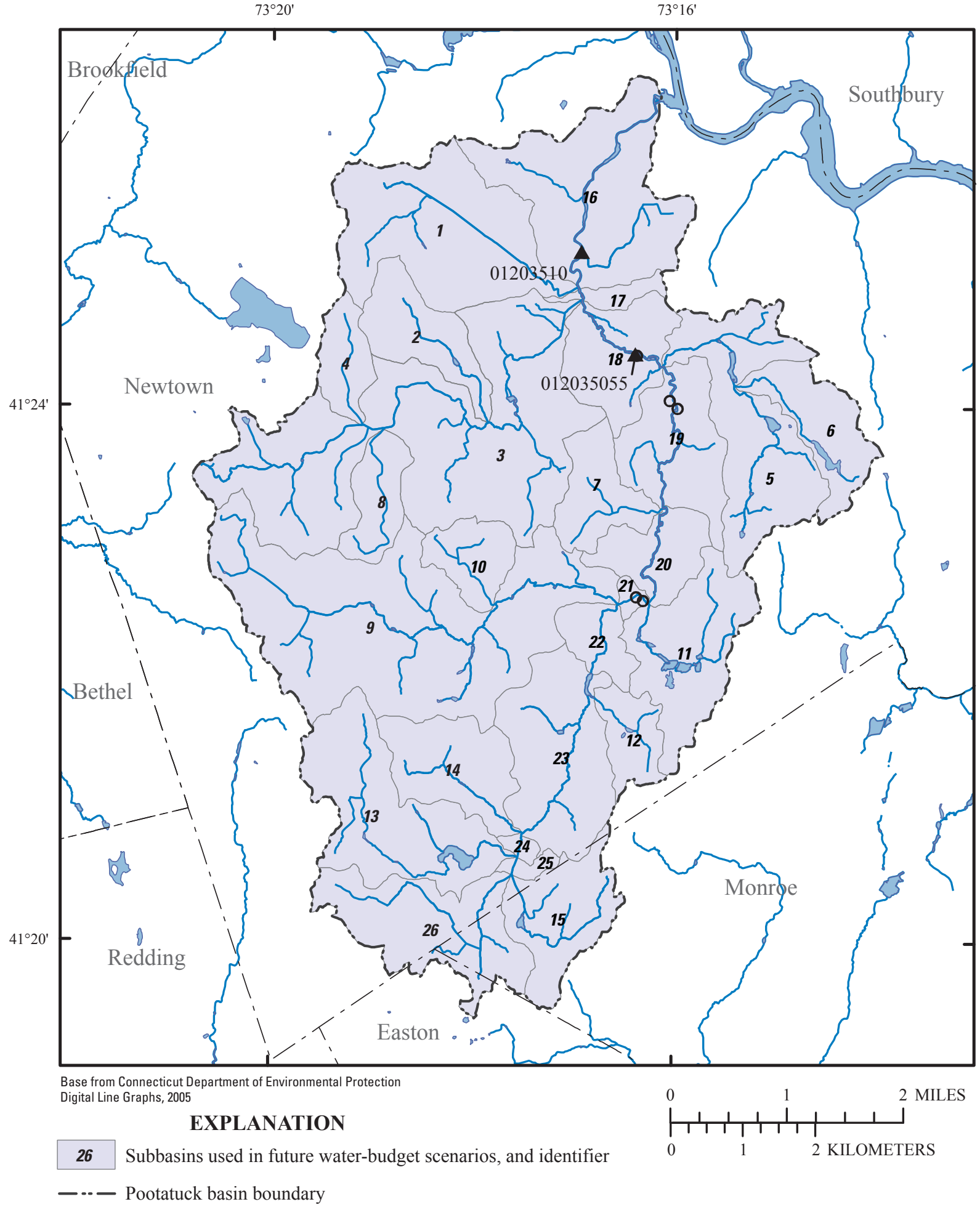

- Continuous-record streamgage, and identifier

○ Production well

Figure 43. Model subbasins in the basin-scale model, Pootatuck River Basin, Newtown, Connecticut. 


\section{Simulated Effect of Future Recharge Conditions}

Future development in the Pootatuck River Basin will affect the amount of recharge to the groundwater system and the areal distribution of that recharge because the percentage of effective impervious cover will change when agricultural and forested land is converted to residential or commercial land uses. The basin-scale, steady-state, groundwater-flow model was used to simulate how these potential changes may affect base flows in the main stem of the Pootatuck River and base flows and water budgets in each of the 26 subbasins of the Pootatuck River Basin.

Three development scenarios were simulated to evaluate the potential effect of future development on recharge, and therefore, on base flow in the Pootatuck River. In each of these scenarios, only the spatially-variable rates of recharge were altered in those areas that could be developed, based on the potential change in effective impervious area. An areally-distributed recharge map was developed for each scenario using the regression equation discussed in an earlier section and in the appendix of this report. No attempt was made to account for potential increasing water needs in the future scenarios because the simulated pumping rates were the registered rates (except for Well 3, which was pumped at 25,000 ft $3 / \mathrm{d}$, still higher than what it was able to pump during the aquifer test).

The town of Newtown provided maps, developed by H.C. Planning Consultants, Inc. (2008), that identified areas that could be developed. It was assumed that future commercial development would have 85 percent effective impervious area (EIA), residential development would have 35 percent EIA, and mixed use development would have 50 percent EIA. Therefore, each of the three development scenarioscommercial, residential, and mixed land-use scenariosaltered recharge in the areas to be developed to account for the increase in impervious area. The commercial land-use scenario simulates the greatest change in recharge (fig. 44). In the discussion that follows, results of each scenario are compared to the calibrated basin-scale, steady-state, groundwater-flow model and changes are noted.

\section{Base Flows in the Main Stem Pootatuck River- Future Scenarios}

The basin-scale model was used to determine changes in the cumulative downstream base flow in the main stem of the Pootatuck River. Simulated base flow under nonpumping and pumping conditions is shown in figure 45 . Changes in base flow caused by pumping become apparent near Wells 1 and
2, the furthest upstream, and increase near Wells 7 and 8 , and again at Well 3.

Changes in the cumulative downstream base flow under potential future recharge scenarios also are shown in figure 45 . The base flow is reduced in each scenario because there is less recharge; the commercial land-use scenario, which represents the greatest increase in impervious area, shows the greatest change. Changes in base flow become apparent very near the headwaters of the Pootatuck River and the hydrographs continue to diverge downstream, although the general shape of the cumulative base flow shown in the figure remains the same.

\section{Water Budgets in Subbasins of Pootatuck River-Future Scenarios}

The simulations of potential future recharge showed variation in the cumulative downstream base flow, flow from individual subbasins, and water budgets in each of 26 subbasins in the Pootatuck River Basin. Base flow decreased in all subbasins because of decreased areal recharge. Most changes because of pumping occurred in subbasins with, and downstream from, production wells (table 18). Subbasin 6, in the headwaters, was the only subbasin with no outflow in any simulation; the stream draining this subbasin crosses from the till uplands onto the more transmissive stratified glacial deposits and loses water to the underlying aquifer.

Change in base flow was the greatest in the commercial land-use scenario because it had the greatest reduction in recharge. Cumulative downstream flow and flow from individual subbasins decreased by more than 20 percent in several subbasins (table 19). Most of these subbasins were located in upland headwater areas and the simulated flow was less than $1 \mathrm{ft}^{3} / \mathrm{s}$. These small changes may be within the expected error of the model. In other, downstream subbasins (16-25), cumulative downstream flow decreased from 10 to 20 percent (table 19) and flow from individual subbasins decreased from 0 to 30 percent (table 20). In the mixed-use and residential land-use scenarios, cumulative downstream flow and flow from individual subbasins decreased by less than $1 \mathrm{ft}^{3} / \mathrm{s}$ (most less than $0.1 \mathrm{ft}^{3} / \mathrm{s}$ ) for most subbasins, with the exception of cumulative base flow in subbasins 16 through 18 in the mixeduse scenario where flows decreased by as much as $1.46 \mathrm{ft}^{3} / \mathrm{s}$ (table 19). Wells 1 and 2 were located in subbasin $21-$ one of the smallest subbasins with an area of $0.1 \mathrm{mi}^{2}$. Stream base flow from subbasin 21 showed a loss and a substantial percent change in flow as compared to the nonpumping simulation (table 20) because of the relatively large amount of pumping at Wells 1 and 2 and the small amount of areal recharge. 


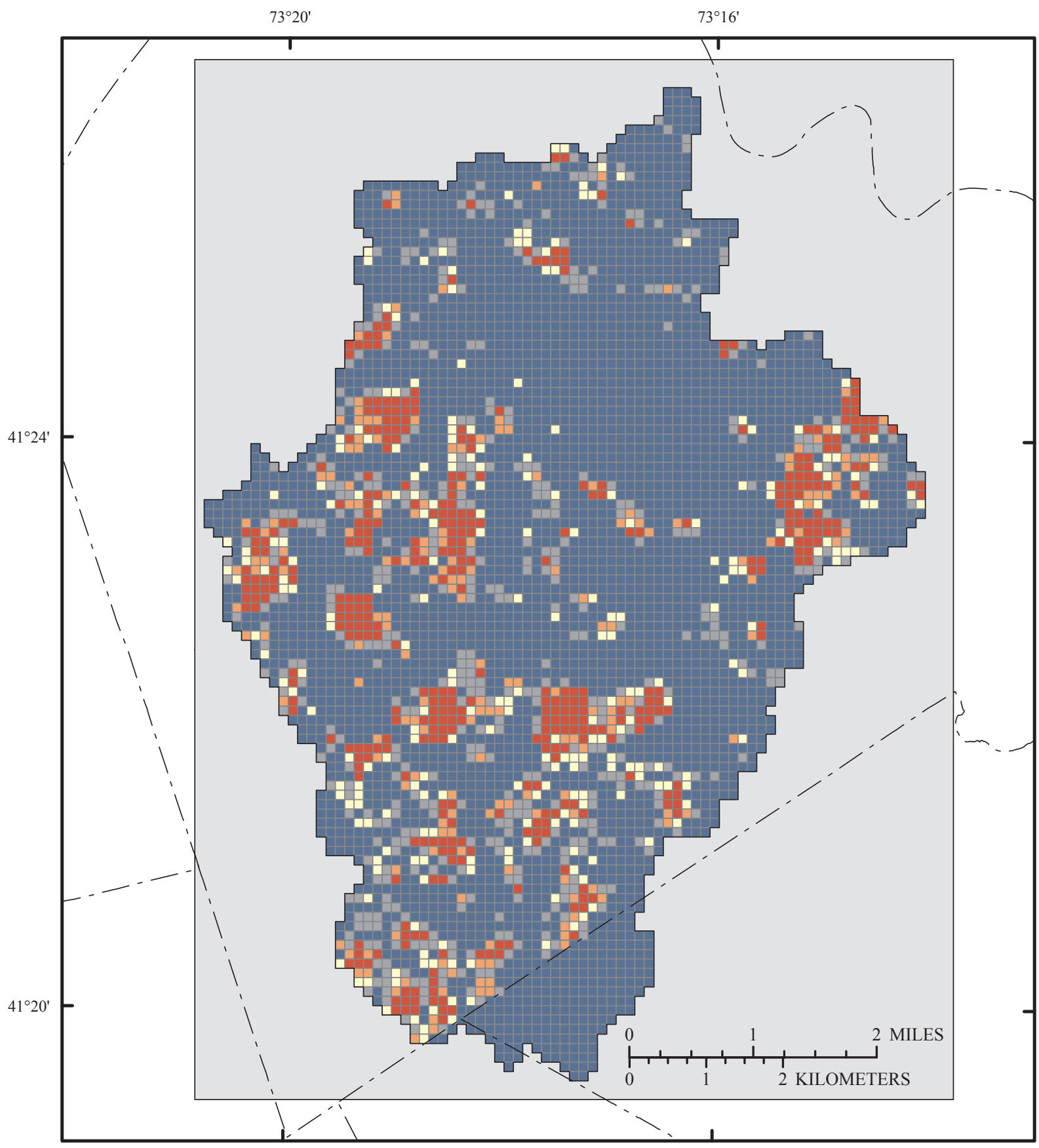

EXPLANATION

Change (reduction) in recharge, in inches per year

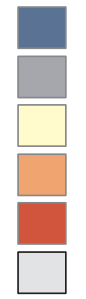

0 to 1

greater than 1 to 3.5

greater than 3.5 to 7

greater than 7 to 11

greater than 11

Inactive model area

- - - Town boundary

Figure 44. Difference in recharge in commercial land-use scenario as compared to the calibrated model, Pootatuck River Basin, Newtown, Connecticut. 


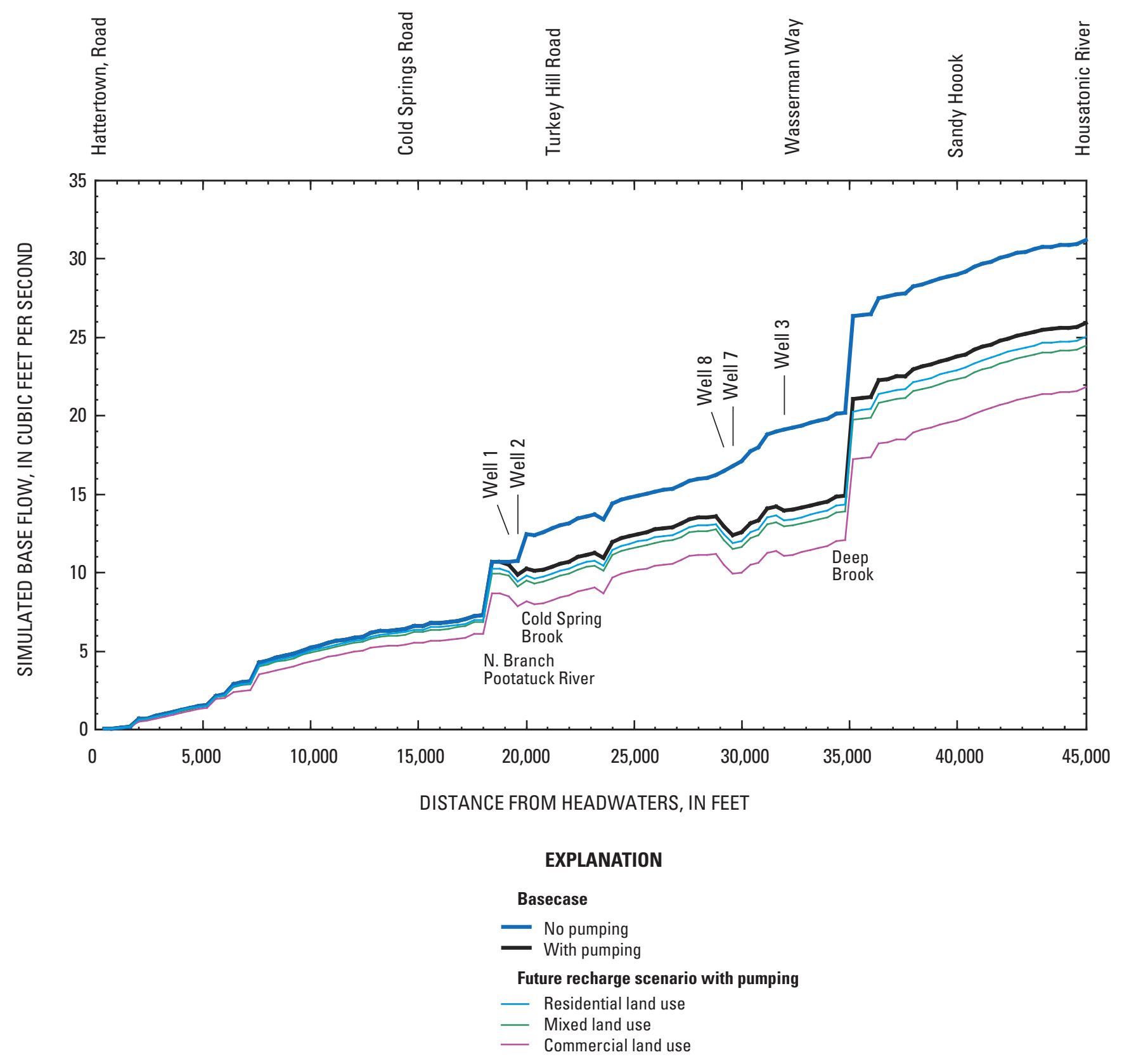

Figure 45. Cumulative downstream base flow in the Pootatuck River for the basin-scale model future-recharge analysis, Newtown, Connecticut. 


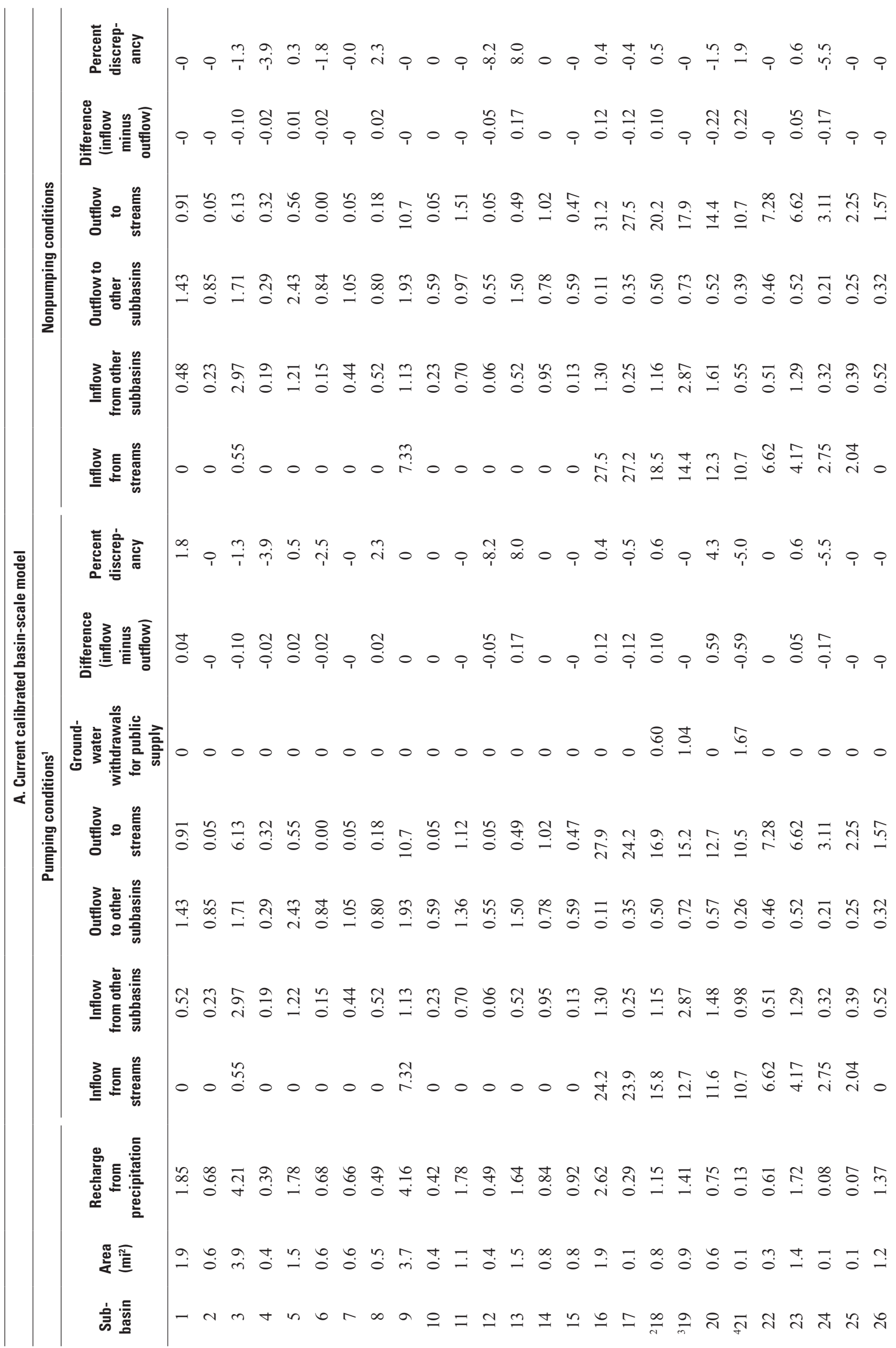




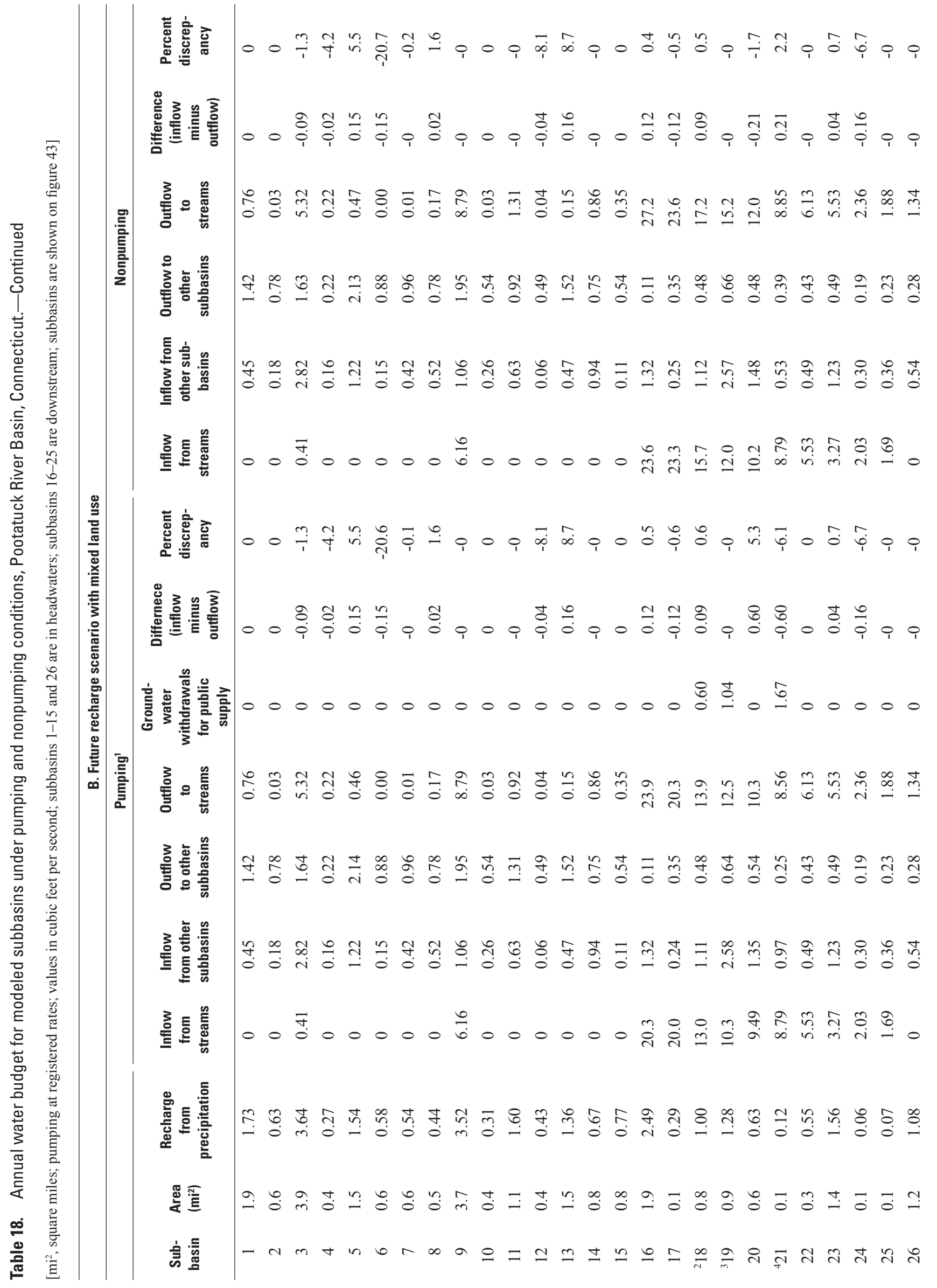




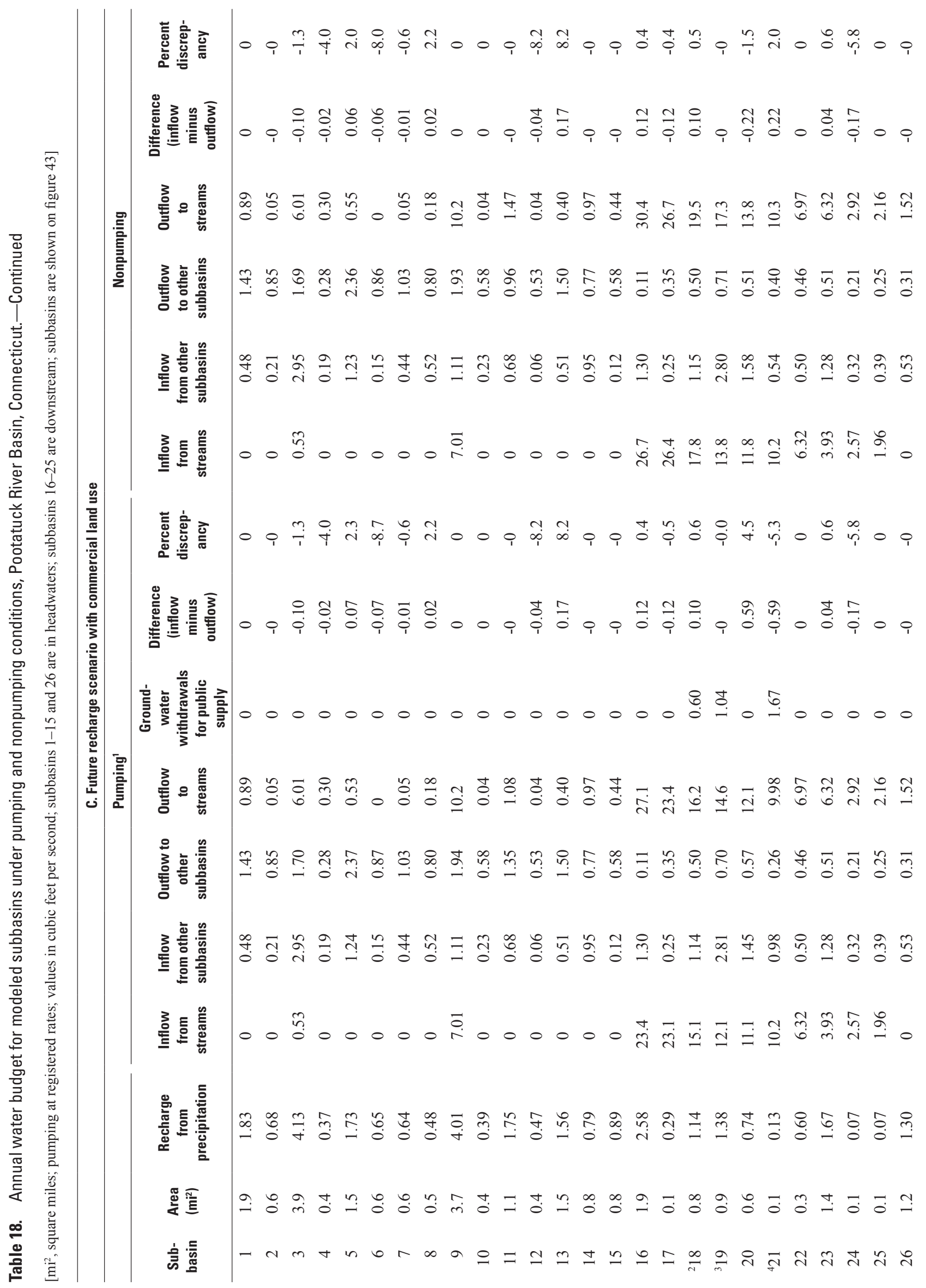




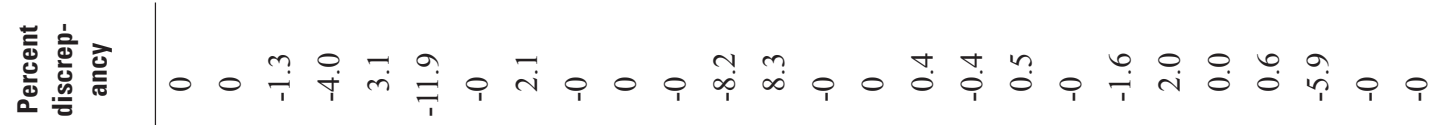

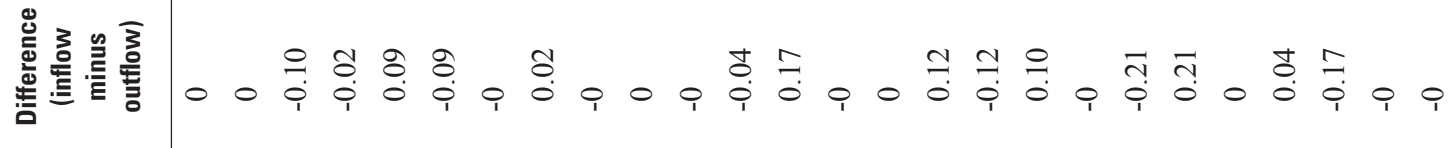

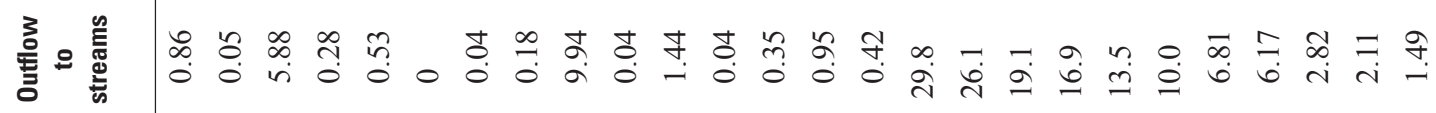

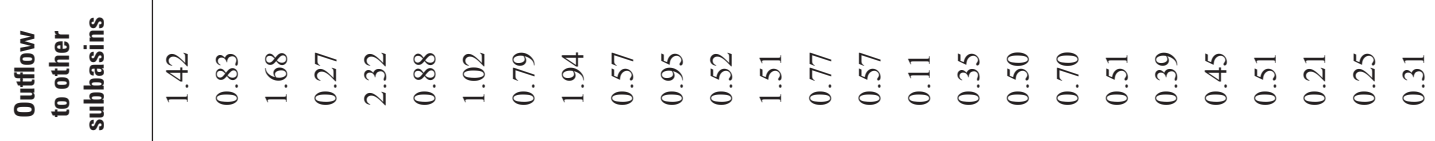

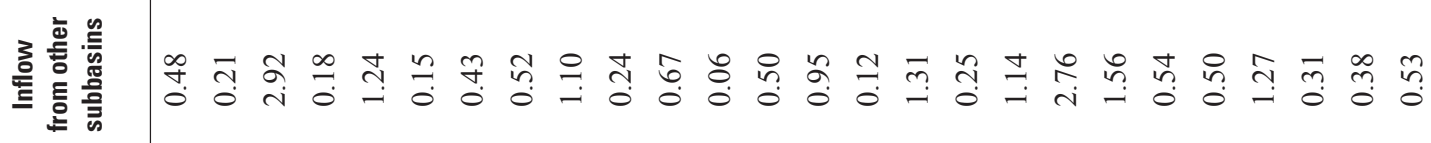

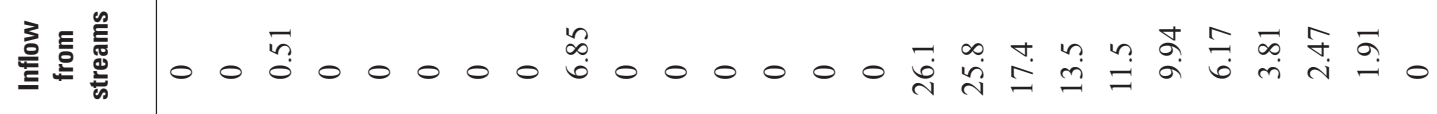

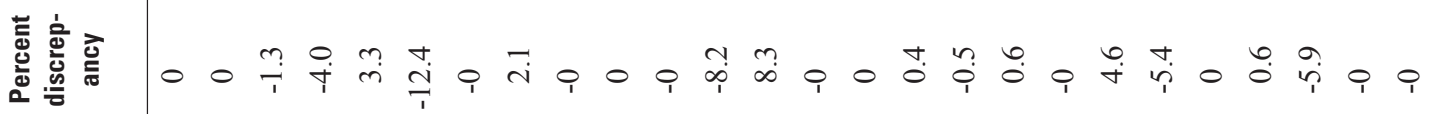

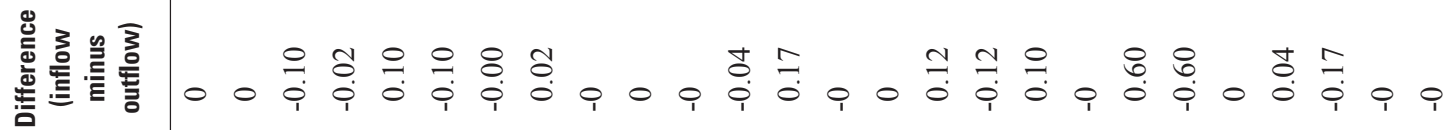

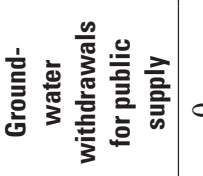

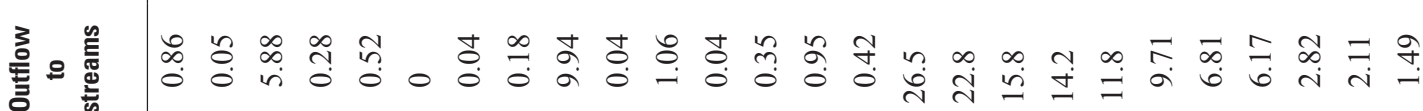

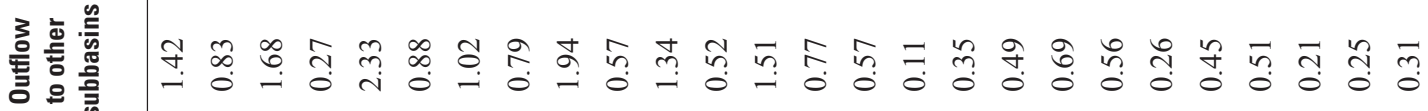

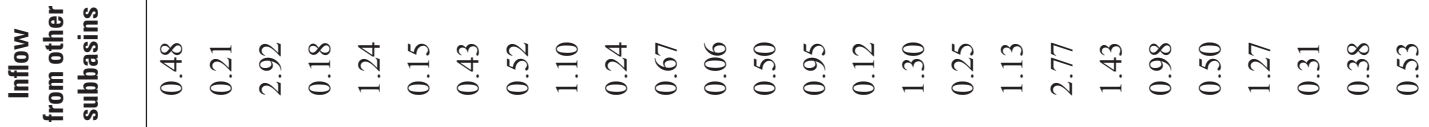
旁至部

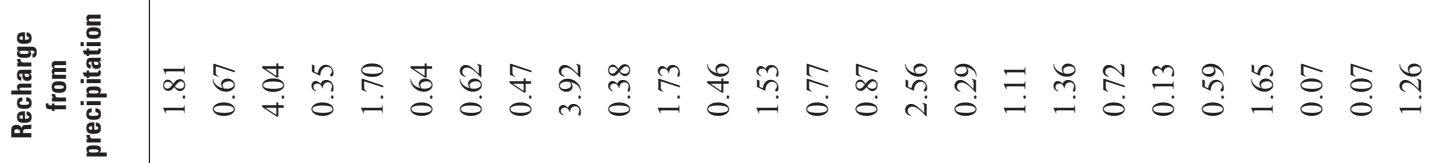
造

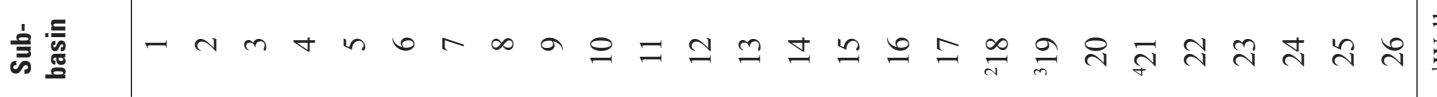




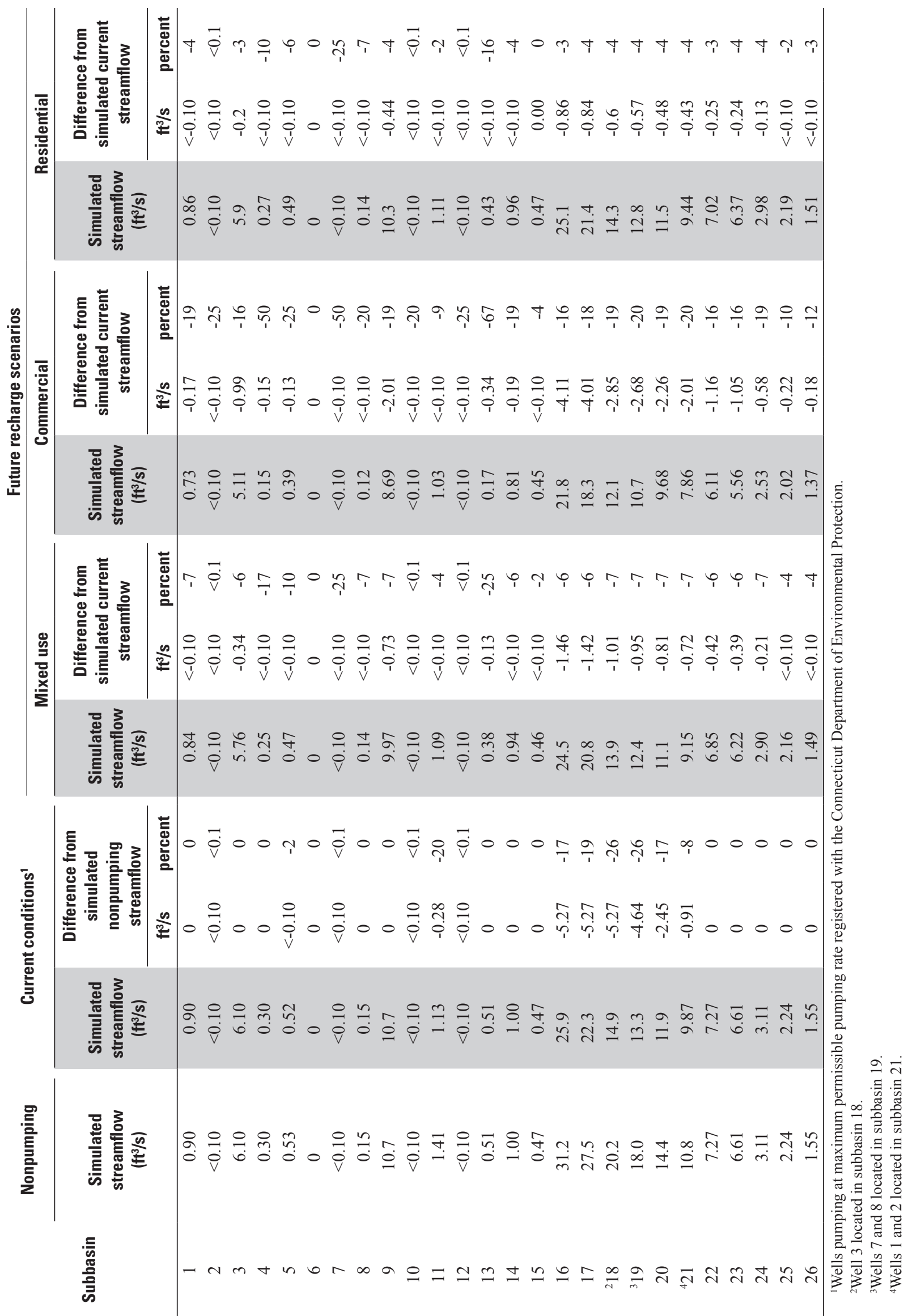




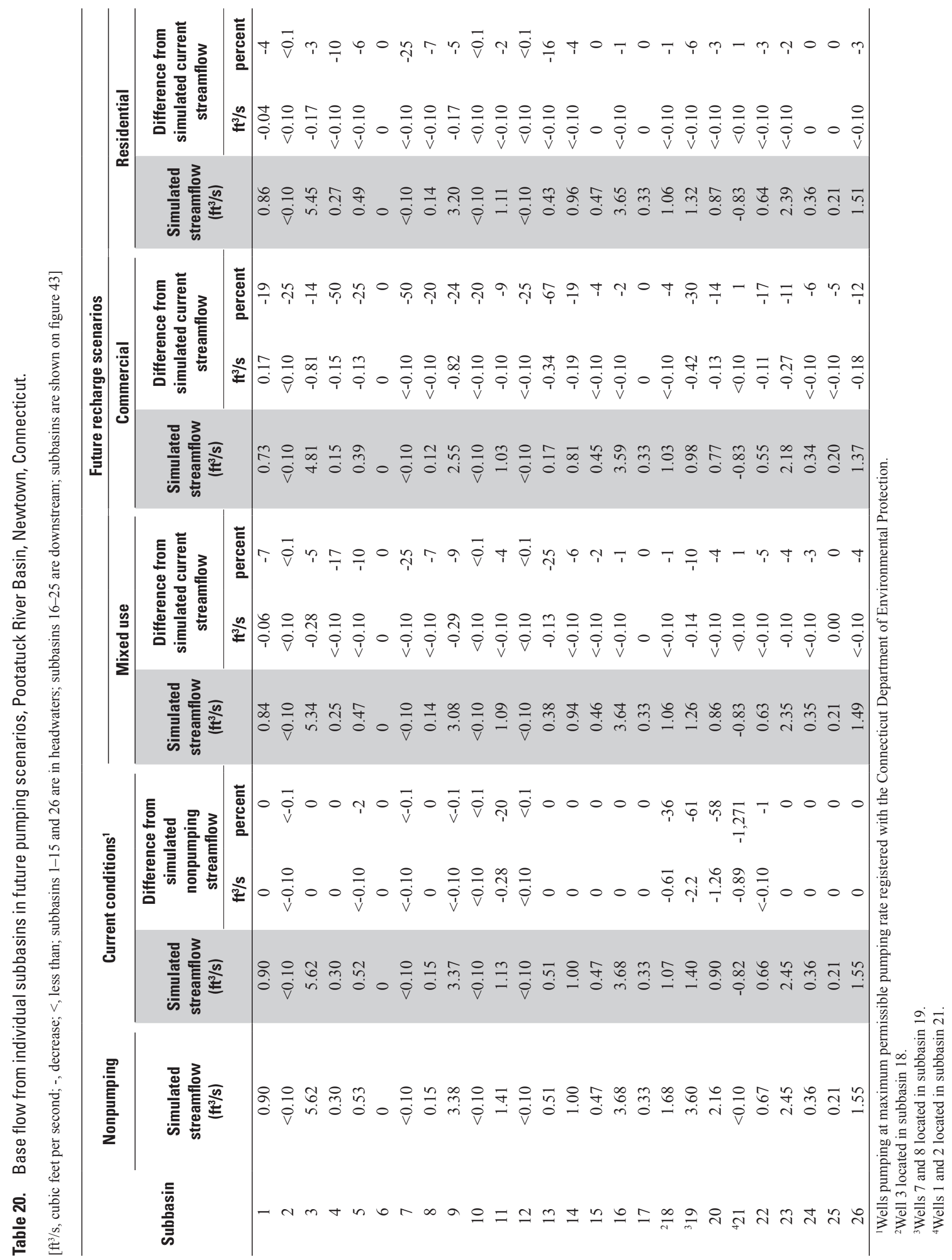




\section{Summary}

The aquifer system that includes stratified glacial, valley-fill sediments and till and bedrock uplands in the Pootatuck River Basin is the sole source of water to Newtown, Connecticut. Continued land development and population growth have caused concerns regarding future water supplies and increasing competition between water for human use and protecting aquatic habitat. To address these concerns, the U.S. Geological Survey and Newtown did a cooperative hydrogeologic study of the Pootatuck River Basin. Three aquifer tests were conducted - two at the Fairfield Hills well field and one at the United Water well field - to determine aquifer properties and the effect of well pumping on the interaction between surface water and groundwater near the wells. Transmissivities calculated using data from the aquifer ranged from 3,200 to $20,000 \mathrm{ft}^{2} / \mathrm{d}$. These data were used in groundwater-flow models of the well fields and the basin.

Several methods were used to analyze the interaction between the stream and the aquifer. During the aquifer test at the Fairfield Hills well field, streamflow increased between the upstream and downstream measuring sites even when the wells were pumping, perhaps because of bank or wetland storage of surface water from recent rain events and groundwater inflow from the opposite side of the stream; however, there was a reduction in the streamflow gain. A similar result was observed in the water-level measurements and stream stage made at each of the streambed piezometers near Well 3; the head gradient indicated groundwater was discharging to the stream, but the gradient was smaller during the pumping phase of the test. The head gradients in the piezometers near Well 7 indicated that during pumping, water moves from the stream into the groundwater system. Groundwater temperatures at various depths in piezometers near Well 3 became more similar to the temperature of the surface water when the well was pumping. This also implied movement of surface water into the aquifer. A similar pattern was observed in a piezometer near Well 7.

Normalized stable-isotope ratios of hydrogen and oxygen, $\delta^{2} \mathrm{H}$ and $\delta^{18} \mathrm{O}$, were used to determine possible mixing of surface water and groundwater at the Fairfield Hills production wells. Samples collected near Well 7 near the end of pumping showed from 32 to 69 percent of the pumped water came from the river and a sample collected near Well 3 near the end of the pumping showed from 68 to 97 percent of the pumped water came from the river.

Lack of water storage precluded running a typical aquifer test on Well 2 at the United Water well field, so data from a previous test were used to calculate transmissivity, and a 9.5-hour production-well recovery test was run to collect data to analyze the effect of the pumping on the surface watergroundwater connection. Stage measurements made at the piezometers indicated there was stream inflow even during the short period when the well was not pumping. When Well 2 was pumping, the temperatures of the groundwater below the streambed were relatively constant and similar to each other with some fluctuation of temperature at a depth of $2 \mathrm{ft}$, implying that surface water flowed to the groundwater system during pumping. When Well 2 was shut down, the temperature at $2 \mathrm{ft}$ below the streambed became less similar to the temperature at the other depths in the piezometers on the near bank of the stream.

Two well-field-scale and one basin-scale threedimensional, numerical groundwater-flow models were developed for the Pootatuck River Basin to (1) synthesize the available hydrogeologic data including aquifer tests (wellfield scale); (2) determine areas contributing recharge to five simulated production wells for steady-state conditions (wellfield scale); and (3) assess the effect of three potential future recharge scenarios on base flow and water budgets in the Pootatuck River (basin scale).

Groundwater-flow models were developed for each well field and calibrated to the data collected at each location. These models were used to determine parameters to be used in a basin-scale model as well as recharge areas at the well-field scale. Calibrated values of hydraulic conductivity for areas representing the stratified glacial deposits ranged from 16 to $60 \mathrm{ft} / \mathrm{d}$ at the Fairfield Hills well field and from 60 to $220 \mathrm{ft} / \mathrm{d}$ at the United Water well field. The calibrated value for the bedrock and till underlying the stratified glacial deposits and in the uplands surrounding the primary aquifer was $3 \mathrm{ft} / \mathrm{d}$.

The simulated and observed water levels from the aquifer test at the Fairfield Hills well field matched reasonably well with mean absolute errors of 1.3 and $0.4 \mathrm{ft}$ for Wells 3 and 7, respectively. Overall, Well 3 and associated observation wells had the best match with median errors that ranged from -1.2 to $-0.2 \mathrm{ft}$; median errors for Well 7 and associated observation wells ranged from -1.5 to $+3.4 \mathrm{ft}$. Two observation wells associated with Well 7 had the worst median errors of -1.5 and $+3.4 \mathrm{ft}$, respectively.

Comparison of simulated and observed water levels from the short-duration, reverse aquifer test at the United Water well field show that the initial water-level increase at the start of the aquifer test and during the transition period into aquifer-test nonpumping conditions match reasonably well, as do those in the transition period to pumping conditions at the end of the aquifer test. For the overall time period of the test, the mean absolute error ranged from +0.4 to $+0.5 \mathrm{ft}$ and the median error for the observation wells ranged from -0.2 to $-0.1 \mathrm{ft}$. During the shutdown, the mean absolute error ranged from +0.9 to $+2.2 \mathrm{ft}$ and the median error ranged from -2.6 to $-0.8 \mathrm{ft}$.

Steady-state models were developed for both well fields and for the basin. Because the amount of recharge to the groundwater system depends on the physical and land-use conditions, an areally-distributed map of recharge was developed for the basin. The estimated recharge averaged $16 \mathrm{in} / \mathrm{yr}$ for the entire basin and ranged from a set value of 1 to $28 \mathrm{in} / \mathrm{yr}$. All five production wells in the Newtown area that are available for use were simulated simultaneously even though it is acknowledged that this is not a normal operating condition. Simulating all five wells provides the most 
conservative estimate of the effect of pumping on the hydrologic system. The total pumping simulated was about 3.41 $\mathrm{Mgal} / \mathrm{d}$, which is the sum of the registered rates.

The calibrated well-field-scale groundwater-flow models were used to define the areas contributing recharge to five simulated production wells in Newtown under steady-state conditions. The results of the modeling showed that water pumped from each well is a combination of groundwater from the recharge area and stream inflow. The percent of the pumped water derived from the recharge area ranged from 20 to 62 percent; therefore, 38 to 80 percent of the pumped water came from the stream. This result is similar to that determined from the stable isotopes described above and potentially has large implications for protection of the quality of the water pumped from the wells.

The basin-scale model was run under steady-state conditions that represent long-term averages and was calibrated to average water levels and streamflow estimated from the nearby Pomperaug River. Because of the scale of the model and the lack of available groundwater measurement points, only seven groundwater calibration points were available. The mean of the residuals at these points was $+1.1 \mathrm{ft}$ and the mean absolute error was $+2.0 \mathrm{ft}$, less than 2.5 percent of the total range $(78 \mathrm{ft})$ in water levels.

The calibrated, basin-scale groundwater-flow model was used to estimate the effect on base flows in the main stem of the Pootatuck River, and base flows and water budgets in each of 26 subbasins under three potential development scenarios. These scenarios assumed impervious area in all newly developed areas would increase to 35,50 , or 85 percent of the total area. The simulations showed that base flow in the main stem of the Pootatuck River is reduced in each future recharge scenario and base flow decreased in all subbasins, with some subbasins showing a decrease of more than 20 percent. For subbasins located in upland headwater areas, recharge from precipitation was the greatest source of water, whereas in subbasins located further downstream and near the Pootatuck River, stream inflow was the greatest source of water. When comparing pumping to nonpumping conditions, the steadystate simulations show that streamflows downstream from a production well are generally decreased by the amount of pumping.

The areas contributing recharge delineated in this investigation and the potential effects of future development on base flow are valid only for the specific pumping, recharge, and aquifer property conditions detailed in this report. If pumping and recharge conditions are modified in the future, or if additional long-term water-level data are collected for different calibration locations in the modeled area, the areas contributing recharge to production wells in the Pootatuck River Basin could be evaluated on the basis of the new conditions and data. The models described in this report can serve as tools to evaluate the recharge areas to production wells in response to future changes in pumping and recharge conditions.

\section{Acknowledgments}

The authors wish to thank the town of Newtown, Newtown Health District, United Water Connecticut Company, Aquarion Operating Services, and the Potatuck Sportsman Club, especially the late John (Jack) Stokes, for the high level of cooperation received in preparation for and conducting the aquifer tests using the Fairfield Hills and United Water production wells. The authors also wish to thank Jeffrey Starn, Joseph DePalma, Karen Beaulieu, Laura Colangelo, and Daniel Wright of the U.S. Geological Survey for their assistance with field work prior to and during the aquifer tests and Virginia de Lima and John Mullaney for help in preparing the manuscript.

\section{References Cited}

Ahearn, E.A., 2010, Regional regression equations to estimate flow-duration statistics at ungaged stream sites in Connecticut: U.S. Geological Survey Scientific Investigations Report 2010-5052, 45 p.

Anderson, M.P., and Woessner, W.W., 1992, Applied groundwater modeling: San Diego, Calif., Academic Press, Inc., $381 \mathrm{p}$.

Barlow, P.M., and Dickerman, D.C., 2001, Numericalsimulation and conjunctive-management models of the Hunt-Annaquatucket-Pettaquamscutt stream-aquifer system, Rhode Island: U.S. Geological Survey Professional Paper 1636, 88 p.

Bjerklie, D.M., Starn, J.J., and Tamayo, Claudia, in press, Estimation of the effects of land use and groundwater withdrawals on streamflow for the Pomperaug River, Connecticut: U.S. Geological Survey Scientific Investigations Report 2010-5114.

Brown, C.J., Starn, J.J, Stollenwerk, K.G., Mondazzi, R.A., and Trombley, T.J., 2009, Aquifer chemistry and transport processes in the zone of contribution to a public-supply well in Woodbury, Connecticut, 2002-06: U.S. Geological Survey Scientific Investigations Report 2009-5051, 158 p.

Clark, I.D., and Fritz, Peter, 1997, Environmental isotopes in hydrogeology: New York, CRC Press LLC, 328 p.

Cooper, H.H., and Jacob, C.E., 1946, A generalized graphical method for evaluating formation constants and summarizing well field history: American Geophysical Union Transactions, v. 27, p. 526-534.

Coplen, T.B., 1994, Reporting of stable hydrogen, carbon, and oxygen isotopic abundances: Pure and Applied Chemistry, v. 66, p. $273-276$. 
Coplen, T.B., Wildman, J.D., and Chen, Julie, 1991, Improvements in the gaseous hydrogen-water equilibration technique for hydrogen isotope ratio analysis: Analytical Chemistry, v. 63, p. 910-912.

Craig, Harmon, 1957, Deuterium-oxygen 18-tritium relationships in natural waters, in New Research Methods in Hydrology, Committee on Research in Water Resources, University of California.

Craig, Harmon, 1961, Isotopic variations in meteoric waters: Science, v. 133, p. 1702-1703.

Darling, W.G., and Bath, A.H., 1988, A stable isotope study of recharge processes in the English chalk: Journal of Hydrology, v. 101, p. 31-46.

DeSimone, L.A., Walter, D.A., Eggleston, J.R., and Nimiroski, M.T., 2002, Simulation of ground-water flow and evaluation of water-management alternatives in the Upper Charles River Basin, eastern Massachusetts: U.S. Geological Survey Water-Resources Investigations Report 02-4234, 94 p.

Dickerman, D.C., Kliever, J.D., and Stone, J.R., 1997, Hydrogeology, water quality, and simulation of ground-waterdevelopment alternatives in the Usequepaug-Queen groundwater reservoir, southern Rhode Island: U.S. Geological Survey Water-Resources Investigations Report, 97-4126, $48 \mathrm{p}$.

Epstein, Samuel, and Mayeda, Toshiko, 1953, Variation of ${ }^{18} \mathrm{O}$ content of waters from natural sources: Geochimica et Cosmochimica Acta, v. 4, no. 5, p. 213-224.

Fishman, M.J., and Friedman, L.C., 1989, Methods for determination of inorganic substances in water and fluvial sediments: U.S. Geological Survey Techniques of WaterResources Investigations, book 5, chap. A1, 545 p.

Förstel, H., 1982, ${ }^{18} \mathrm{O} /{ }^{16} \mathrm{O}$ ratio of water in plants and their environment, in Schmidt, H.L., Förstel, H., and Heinzinger, K., eds., Stable isotopes: Amsterdam, The Netherlands, Elsevier, p. 503-516.

Franke, O.L., Reilly, T.E., Pollock, D.W., and LaBaugh, J.W., 1998, Estimating areas contributing recharge to wells, lessons from previous studies: U.S. Geological Survey Circular 1174, $14 \mathrm{p}$.

Friesz, P.J., 2004, Delineation of areas contributing recharge to selected public-supply wells in glacial valley-fill and wetland settings, Rhode Island: U.S. Geological Survey Scientific Investigations Report 2004-5070, 64 p.

Gat, J.R., 2008, The isotopic composition of evaporating waters - review of the historical evolution leading up to the Craig-Gordon model: Isotopes in Environmental and Health Studies, v. 44, p. 5-9.
Grady, S.J., and Weaver, M.F., 1988, Preliminary appraisal of the effects of land use on water quality in stratified-drift aquifers in Connecticut-U.S. Geological Survey Toxic Waste-Ground-Water Contamination Program: U.S. Geological Survey Water-Resources Investigations Report 87-4005, $41 \mathrm{p}$.

Granato, G.E., Barlow, P.M., and Dickerman, D.C., 2003, Hydrogeology and simulated effects of ground-water withdrawals in the Big River area, Rhode Island: U.S. Geological Survey Water-Resources Investigations Report 03-4222, $76 \mathrm{p}$.

Haeni, F.P., 1978, Computer modeling of groundwater availability in the Pootatuck River Valley, Newtown, Connecticut: U.S. Geological Survey Water-Resources Investigations Report 78-77, 64 p.

H.C. Planning Consultants, Inc., 2008, Newtown, buildout analysis \& population projections, $21 \mathrm{p}$.

Halford, K.J., and Kuniansky, E.L., 2002, Documentation of spreadsheets for the analysis of aquifer-test and slug-test data: U.S. Geological Survey Open-File Report 02-197, $51 \mathrm{p}$.

Harbaugh, A.W., Banta, E.R., Hill, M.C., and McDonald, M.G., 2000, MODFLOW-2000, the U.S. Geological Survey modular groundwater model-User guide to modularization concepts and the ground-water flow process: U.S. Geological Survey Open-File Report 00-92, 121 p.

Konikow, L.F., and Reilly, T.E., 1999, Groundwater modeling, in Delleur, J.W., ed., The handbook of groundwater engineering: Boca Raton, Fla., CRC Press, 40 p.

Kruseman, G.P., and DeRidder, N.A., 1990, Analysis and evaluation of pumping test data ( $2 \mathrm{~d}$ ed.), Publication 47, International Institute for Land Reclamation and Improvement, Wageningen, The Netherlands, $370 \mathrm{p}$.

Leavesley, G.H., Restrepo, P.J., Markstrom, S.L, Dixon, M., and Stannard, L.G., 1996, The modular modeling system (MMS) - Users manual: U.S. Geological Survey Open-File Report 96-151.

Mastin, M.C., and Vaccaro, J.J., 2002, Documentation of precipitation runoff modeling system modules for the modular modeling system modified for the watershed and river systems management program: U.S. Geological Survey Open-File Report 02-362.

Mazzaferro, D.L., 1986, Ground-water availability and water quality in Southbury and Woodbury, Connecticut: U.S. Geological Survey Water-Resources Investigations Report 84-4221, 105 p. 
Mazzaferro, D.L., Handman, E.H., and Thomas, M.P., 1979, Water resources inventory of Connecticut, part 8, Quinnipiac River Basin: Connecticut Water Resources Bulletin 27, 88 p.

McDonald, M.G., and Harbaugh, A.W., 1988, A modular three-dimensional finite-difference ground-water flow model: U.S. Geological Survey Techniques of WaterResources Investigations, book 6, chap. A1, 586 p.

McKeegan, D.K., 1986, Depth to bedrock and classification of unconsolidated materials above the water table in stratifieddrift areas of part of the Pootatuck River Valley, Newtown, Connecticut: U.S. Geological Survey Miscellaneous Investigations Series, Map I-1702.

Miller, D.R., Warner, G.S., Ogden, F.L., and DeGaetano, A.T., 2002, Precipitation in Connecticut: Storrs, Conn., Connecticut Institute of Water Resources, University of Connecticut, $66 \mathrm{p}$.

Pollock, D.W., 1994, User's guide to MODPATH/ MODPATH_PLOT, version 3-A particle tracking postprocessing package for MODFLOW, the U.S. Geological Survey modular three-dimensional finite-difference groundwater-flow model: U.S. Geological Survey Open-File Report 94-464, 234 p.

Pool, D.R., and Dickinson, J.E., 2007, Ground-water flow model of the Sierra Vista subwatershed and Sonoran portions of the Upper San Pedro Basin, Southeastern Arizona, United States, and Northern Sonora, Mexico: U.S. Geological Survey Scientific Investigations Report 2006-5228, 60 p.

Prudic, D.E., 1989, Documentation of a computer program to simulate stream-aquifer relations using a modular, finitedifference, ground-water flow model: U.S. Geological Survey Open-File Report 88-729, 113 p.

Reilly, T.E., 2001, System and boundary conceptualization in ground-water flow simulation: U.S. Geological Survey Techniques of Water-Resources Investigations, book 3 , chap. B8, 38 p.
Reilly, T.E., and Harbaugh, A.W., 2004, Guidelines for evaluating ground-water flow models: U.S. Geological Survey Scientific Investigations Report 2004-5038, 30 p.

Reilly, T.E., and Pollock, D.W., 1993, Factors affecting areas contributing recharge to wells in shallow aquifers: U.S. Geological Survey Water-Supply Paper 2412, 21 p.

Rodgers, John (compiler), 1985, Bedrock geological map of Connecticut: Connecticut Geological and Natural History Survey, Natural Resources Atlas Series Map, 2 sheets, scale $1: 125,000$.

Starn, J.J., Stone, J.R., and Mullaney, J.R., 2000, Delineation and analysis of uncertainty of contributing areas to wells at the Southbury Training School, Southbury, Connecticut: U.S. Geological Survey Water-Resources Investigations Report 00-4158, 52 p.

State of Connecticut Department of Environmental Protection, 1991, Regulations for mapping wells in stratified drift to level A mapping standards, General Statutes Section $22 \mathrm{a}-354 \mathrm{~b}-1,27 \mathrm{p}$.

Stone, J.R., Schafer, J.P., London, E.H., DiGiacomo-Cohen, M., Lewis, R.S., and Thompson, W.B., 1998, The Quaternary geologic map of Connecticut and Long Island Sound Basin: U.S. Geological Survey Open-File Report 98-371, $72 \mathrm{p}$.

Stone, J.R., Schafer, J.P., London, E.H., and Thompson, W.B., 1992, Surficial materials map of Connecticut: U.S. Geological Special Map, 2 sheets, scale 1:125,000.

Stonestrom, D.A., and Constantz, Jim, eds., 2003, Heat as a tool for studying the movement of ground water near streams: U.S. Geological Survey Circular 1260, 96 p.

Wilson, W.E., Burke, E.L., and Thomas, C.E., Jr., 1974, Water resources inventory of Connecticut, part 5, lower Housatonic River Basin: Connecticut Water Resources Bulletin 19, 79 p.

Zimmermann, U., Ehhalt, D., and Münnich, K.O., 1967, Soil water movement and evapotranspiration - Changes in the isotope composition of water, in Isotopes in hydrology: Vienna, International Atomic Energy Agency, p. 567-84.4. 


\section{Appendix. Spatially-Distributed Recharge}

The amount of recharge at a given location is a function of the physical and land-use conditions in the basin. A distributed recharge map was created for the Pootatuck River Basin based on a statistical relation between various basin characteristics and recharge that was developed for the adjacent Pomperaug River Basin (Bjerklie and others, in press). The relation was developed using a precipitation runoff modeling system basin model (PRMS), developed by the U.S. Geological Survey (Leavesley and others, 1996; Mastin and Vaccaro, 2002).

In the PRMS model, the key physical attributes of the land surface that control runoff quantity and source are the (1) surficial geology; (2) soil type; (3) land cover-in particular the amount of effective impervious surface; and (4) drainage density, which is a measure of the length of streams within a specified subbasin. These attributes are described below.

- Surficial Geology - the presence of coarse stratified glacial deposits (sands and gravels) as a percent of the total area of each subbasin. These deposits form the principal water-bearing units in the basin and transmit the greatest amount of water to production wells.

- Soil Type-The important soil type is the class D soils (also known as Hydrologic Soil Group D), which are clayey soils with low permeability. These soils hold water but do not readily transmit water vertically (as recharge to groundwater) and thus tend to cause higher surface runoff and a higher permanent water table.

- Percent Effective Impervious Surface-Impervious surfaces prevent vertical recharge of precipitation and result in high surface runoff, especially where the runoff from these surfaces is collected in storm drains and routed directly into streams. Effective impervious surface is a part of the total impervious surface, and acknowledges that some runoff from impervious areas does infiltrate the ground. Effective impervious cover was estimated using a method developed for Connecticut (Bjerklie and others, in press). This was based on estimation of total impervious area using the Impervious Surface Analysis Tool (ISAT) described by Chabaeva and others (2004) and coefficients developed for Connecticut land-use and population-density classes (Prisloe and others, 2003).

- Drainage Density - The drainage density (length of stream per unit area) is an indicator of the perennial drainage characteristics of the subbasin. Where the density is higher and the drainage network is well established, a more stable discharge regime is indicated, which also indicates groundwater dominance.
The effect of the key physical factors on groundwater recharge was assessed in the model by multiple linear regression analysis. The simulated recharge was regressed against the physical attributes listed above for each subarea in the PRMS, and a simplified predictive equation derived. The drainage density provided only marginal improvement in the regression and was not included as a predictor variable. The resulting equation was,

$$
R=c 1 E l A+c 2 C S D+c 3 \text { Class } D+c 4
$$

where

$\begin{aligned} & R \text { is the recharge, in inches per year, } \\ & c 1-c 4 \text { are regression coefficients } \\ & E I A \text { is the effective impervious cover, in fractional } \\ & \text { percent, }\end{aligned}$

The coefficients of the derived regression equation and their statistical significance are shown in table 21 . The negative values for the coefficient of effective impervious cover and Class D soils indicate that these variables reduce recharge; the positive value for the coefficient of coarse stratified glacial deposits indicates this variable increases recharge.

Table 21. Coefficients and statistics for regression equation to determine groundwater recharge, Pootatuck River Basin, Newtown, Connecticut.

[EIA, effective impervious area; CSD, coarse stratified glacial deposits; ClassD, Class D soils; $\operatorname{Pr}(>|t|)$, probability value is not significant at 95 -percent probability level]

\begin{tabular}{lccc}
\hline Variable & Value & Standard error & $\operatorname{Pr}(>|\mathbf{t}|)$ \\
\hline EIA & -0.1049 & 0.0280 & 0.0004 \\
CSD & 0.0386 & 0.0043 & 0.0000 \\
ClassD & -0.0419 & 0.0108 & 0.0003 \\
Intercept & 0.0392 & 0.0019 & 0.0000 \\
\hline
\end{tabular}

The regression statistics for the equation are:

Residual standard error: 0.009473 on 60 degrees of freedom, Multiple R-Squared: 0.6395 , Adjusted R-squared: 0.6215 , F-statistic: 35.48 on 3 and 60 degrees of freedom, and p-value: $2.57 \mathrm{e}-013$. 


\section{References}

Bjerklie, D.M., Starn, J.J., and Tamayo, Claudia, in press, Estimation of the effects of land use and groundwater withdrawals on streamflow for the Pomperaug River, Connecticut: U.S. Geological Survey Scientific Investigations Report 2010-5114.

Chabaeva, A.A., Civco, D.L., and Prisloe, S., 2004, Development of a population and land use based regression model to calculate the amount of imperviousness, in Proceedings of the annual ASPRS convention, Denver, Colorado, 2004, 9 p., accessed on September 10, 2009, at http://nemo.uconn.edu/tools/impervious_surfaces/pdfs/ Chabaeva_etal_2004.pdf.

Leavesley, G.H., Restrepo, P.J., Markstrom, S.L., Dixon, M., and Stannard, L.G., 1996. The modular modeling system (MMS) - Users manual: U.S. Geological Survey Open-File Report 96-151.

Mastin, M.C., and Vaccaro, J.J., 2002, Documentation of precipitation runoff modeling system modules for the modular modeling system modified for the watershed and river systems management program: U.S. Geological Survey Open-File Report 02-362.

Prisloe, M., Wilson, E.H., and Arnold, C., 2003, final reportRefinement of population-calibrated land-cover-specific impervious surface coefficients for Connecticut: Nemo FY02 Workplan, DEP project 01-08, University of Connecticut, Middlesex County Extension Center, 20 p. 
Prepared by the Pembroke and Lafayette Publishing Service Centers.

For more information concerning this report, contact:

Director

U.S. Geological Survey

Connecticut Water Science Center

101 Pitkin Street

East Hartford, CT 06108

dc_ct@usgs.gov

or visit our Web site at:

http://ct.water.usgs.gov 
